\title{
Summary of the Research and Development Effort on Open-Cycle Coal-Fired Gas Turbines
}

\author{
M. E. Lackey
}

MASTER

\section{OAK RIDGE NATIONAL LABORATORY} OPERATED BY UNION CARBIDE CORPORATION · FOR THE DEPARTMENT OF ENERGY 


\section{DISCLAIMER}

This report was prepared as an account of work sponsored by an agency of the United States Government. Neither the United States Government nor any agency Thereof, nor any of their employees, makes any warranty, express or implied, or assumes any legal liability or responsibility for the accuracy, completeness, or usefulness of any information, apparatus, product, or process disclosed, or represents that its use would not infringe privately owned rights. Reference herein to any specific commercial product, process, or service by trade name, trademark, manufacturer, or otherwise does not necessarily constitute or imply its endorsement, recommendation, or favoring by the United States Government or any agency thereof. The views and opinions of authors expressed herein do not necessarily state or reflect those of the United States Government or any agency thereof. 


\section{DISCLAIMER}

Portions of this document may be illegible in electronic image products. Images are produced from the best available original document. 


\section{Printed in the United States of America. Available from National Technical Information Service \\ U.S. Department of Commerce 5285 Port Royal Road, Springfield, Virginia 22161 NTIS price codes-Printed Copy: A07 Microfiche A01}

This report was prepared as an account of work sponsored by an agency of the United States Government. Neither the United States nor any agency thereof, nor any of their employees, makes any warranty, expressed or implied, or assumes any legal liability or responsibility for any third party's use or the results of such use of any information, apparatus, product or process disclosed in this report, or represents that its use by such third party would not infringe privately owned rights. 
Contract No. W-7405-eng-26

Englneering Technology Division

\section{SUMMARY OF THE RESEARCH AND DEVELOPMENT EFFORT ON OPEN-CYCLE COAL-FIRED GAS TURBINES}

M. E. Lackey

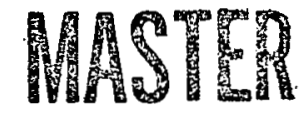

\section{Date Published: October 1979}

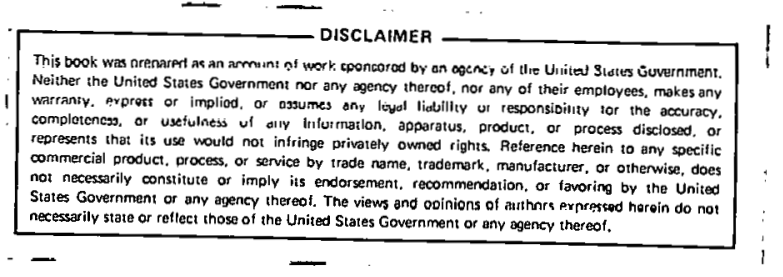

NOTICE This document contains information of a preliminary nature. It is subject to revision or correction and therefore does not represent a final report.

Prepared by the OAK RIDGE NATIONAL LABORA'IORY

Oak Ridge, Tennessee 37830

operated by

UNION CARBIDE CORPORATION

for the

DEPARTMENT OF ENERGY 


\section{THIS PAGE}

\section{WAS INTENTIONALLY LEFT BLANK}


Page

ACKNOWLEDGMENT $\ldots \ldots \ldots \ldots \ldots \ldots \ldots \ldots \ldots \ldots \ldots \ldots \ldots \ldots \ldots \ldots$

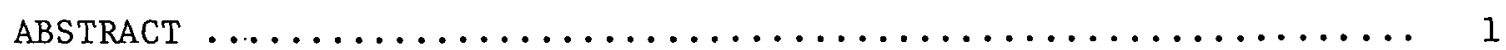

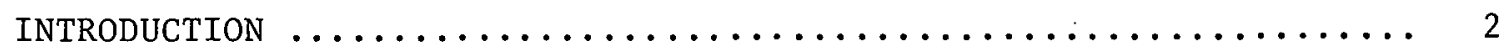

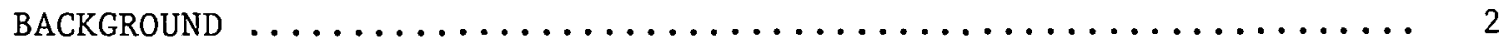

System Description ............................. 2

Advantages and Disadvantages ........................ 3

Operating Experience ........................... 3

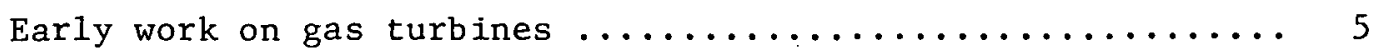

Locomotive development committee ................. 5

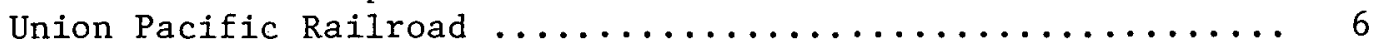

Bureau of Mines ........................... 6

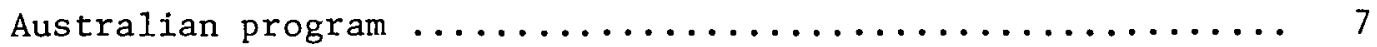

Catalytic-cracking units ...................... 8

Gas turbines operated on low-Btu gas from blast

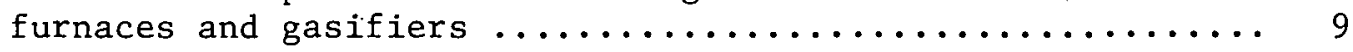

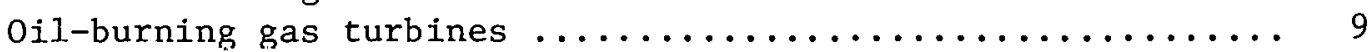

Cascade tests with fluidized beds at BCURA ............. 10

Combustion Power Company ........................ 10

Turbosupercharged fluidized-bed furnaces for

steam generators ........................... 11

Accumulated Costs and Running time .................... 11

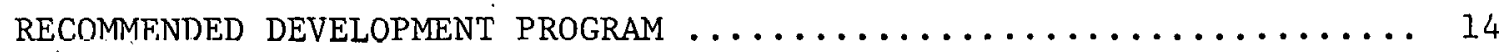

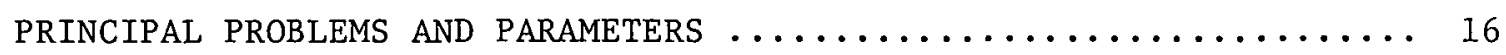

Erosion $\ldots \ldots \ldots \ldots \ldots \ldots \ldots \ldots \ldots \ldots \ldots \ldots \ldots \ldots \ldots \ldots \ldots \ldots$

Effects of particle character and angle of

incidence ............................ 17

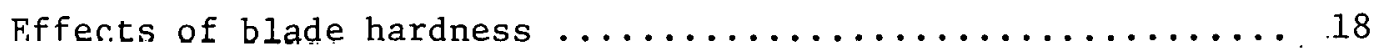

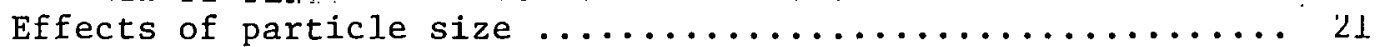

Effects of particle velority ..................... 22

Effects of particulate content of the gas stream ......... 24

Deposits ........................................... 24

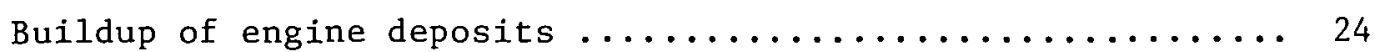

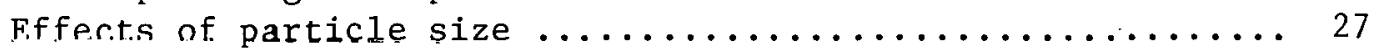

Effects of particle temperature .................... 27

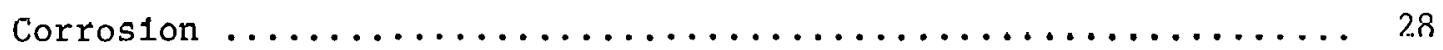

Effects of temperature ........................ 28

Effects of type of coal .......................... 29

Particle Separators .............................. 29 


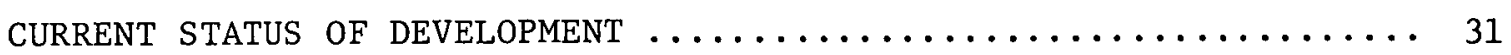

Exxon Research and Engineering Company ................ 33

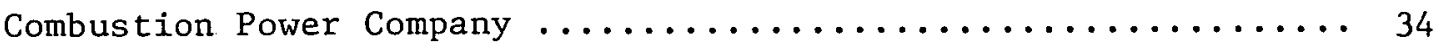

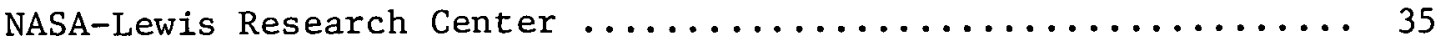

West1nghouse Research and Development Center ............ 35

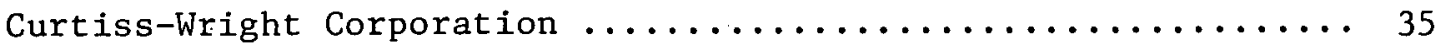

Deposits of Particulates Entering with the Inlet Air ........ 36

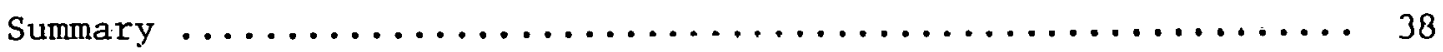

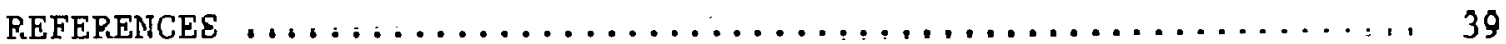

APPENDTX A: SUMMARY OF LITERATURF CONCERNING THE RESEARCH AND DEVELOPMENT EFFORT ON OPEN-CYCLE

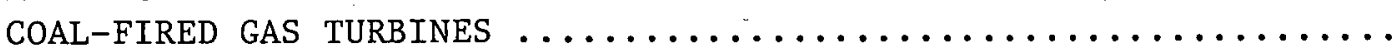




\section{ACKNOWLEDGMENT}

Many people contributed material for this report and their assistance is deeply appreciated. A special debt is owed R. T. Sawyer, who gave access to his extensive files and provided a full set of reports of the Locomotive Development Committee of Bituminous Coal Research, Inc. Others who kindly contributed material and/or assisted in the review of the manuscript include E. L. Daman of Foster-Wheeler; A. Cohn and S. Ehrlich of EPRI; R. D. Brooks and J.,L. Mangan of the General Electric Co.; R. C. Hoke and $\mathrm{H}$. Shaw of Exxon Research \& Engineering Co.; R. Cole and J. Mogul of the Curtiss-Wright Corporation; K. E. Phillips of Combustion Cu.; E. P. Weinert and G. Katz of the Naval Ship Engineering Center; and R. W. FosterPegg, S. M. DeCorso, G. Vermes, and R. Chamberlin of Westinghouse. 


\title{
SUMMARY OF THE RESEARCH AND DEVELOPMENT EFFORT ON OPEN-CYCLE COAL-FIRED GAS TURBINES
}

\author{
M. E. Lackey
}

\begin{abstract}
The extensive experience gained with gas turbines operating not only with coal as fuel but also with dusty inlet air and with dirty fucls (such as heavy oils and blast furnace gas) as well as petroleum catalytic cracking units has been reviewed. All this experience indicates that the particulate content of the hot gases fed to the turbine must be kept to less than 11 ppm to keep turbine bucket erosion to an acceptable level for turbine inlet temperatures of $1500^{\circ} \mathrm{F}\left(815^{\circ} \mathrm{C}\right)$ or more. Dropping the turbine inlet temperature below $1110^{\circ} \mathrm{F}\left(600^{\circ} \mathrm{C}\right)$ makes it possible to obtain turbine bucket lives of around three years with $\sim 100$ ppm of particulates if a number of compromises are made in the turbine design.

A buildup of deposits in the turbine is a serious problem if sulfates or chlorides are present in the gas stream and the turbine inlet temperature is above $21110^{\circ} \mathrm{F}\left(600^{\circ} \mathrm{C}\right)$. At this temperature level, these materials become soft and sticky and form films on the blades that act like "flypaper" and accumulate deposits of the silicates and oxides present in the ash of a coal-fired combustor. Problems with deposits become particularly severe at temperatures above $2000^{\circ} \mathrm{F}\left(1093^{\circ} \mathrm{C}\right)$; difficulties have been experienced with inlet air dust concentrations less than $0.1 \mathrm{ppm}$.

Extensive experience with many types of cyclone separators shows that they can be used to reduce the particulate content to as low as $\sim 100 \mathrm{ppm}$ under the best conditions. Granular bed filters have yielded similar performance. Electrostatic precipitators are not effective above $\sim 1110^{\circ} \mathrm{F}\left(600^{\circ} \mathrm{C}\right)$ because the dúst deposits on insulators become conducting and short out the grids. The only effective way found to reduce the particulate content of blast furnace gas and gas from coal gasification units to the $\sim 1 \mathrm{ppm}$ required for a high-temperature gas turbine is to cool the gas and pass it through a two-stage water scrubber or equivalent before burning it.

In brief, it appears doubtful that any of the hot-gas clean-up concepts being investigated will yield the low particulate contents requited for the satisfactory, economical operation of 1500 to $1600^{\circ} \mathrm{F}$ ( 816 to $870^{\circ} \mathrm{C}$ ) long-lived gas tubines. However, the technology is available for satisfactory service if the turbine inlet temperature is kept below $1110^{\circ} \mathrm{F}\left(600^{\circ} \mathrm{C}\right)$.
\end{abstract}


INTRODUCTION

This is one of a series of topical reports summarizing the research and development ( $R \& D)$ effort on various phases of advanced power conversion systems. ${ }^{1}$ This report is especially concerned with the possibility of employing an open-cycle coal-fired gas turbine with a pressurized fluidized-bed combustor.

The first portion of this report presents a background history of the research and development effort on coal-fired gas turbines up to 1976 . The next section discusses recommended development prugralls and priorities. This is followed by a presentation of the principal problem areas, performance parameters, and figures of merit characteristic of the system to provide perspective on the various problems. The principal parameters and figures of merit include such quantities as the operating life of experimental units, turbine inlet temperature, particulate content of the turbine inlet gas, etc. Subsequent sections summarize the current. status of development and experience in system research and development work.

This work was carried out at the request of the Office of Program Planning and Analysis, Fossil Energy Program, Department of Energy with funds provided for a general appraisal of advanced fossil energy systems.

\section{BACKGROUND}

Work on coal-burning gas turbines began in 1944 but was largely phased out by 1960 because of serious difficulties with turbine bucket erosion and deposits. Interest in the open-cycle coal-burning gas turbine has been renewed in recent years, primarily because it offers the possibility of pressurizing a fluidized-bed coal combustor for a combined cycle system. ${ }^{2-4}$

\section{System Decription}

The system commonly envisioned currently is a combined gas turbinesteam cycle in which the bulk of the heat of combustion released in a 
fluidized-bed coal combustor is transferred to a steam generator tube matrix in the fluidized bed while the balance of the heat in the hot combustion products flows to a gas turbine. The gas turbine drives the compressor (with a pressure ratio of $\sim 10: 1$ ) and the generator. A flowsheet for a typical system is shown in Fig. 1. Note the particle removal equipment between the fluidized bed and the gas turbine.

\section{Advantages and Disadvantages}

The system shown in Fig. 1 has the advantage that it would give a somewhat higher thermal efficiency than a steam cycle alone because of the extra power obtained from the gas turbine topping cycle ${ }^{4}$ and because absorbing the sulfur from the coal in the fluidized bed should eliminate the losses associated with stack gas scrubbers. ${ }^{2}$ A further advantage is that pressurization of the furnace greatly reduces its size and capital cost and the number of coal feed points, which means a reduction in the complexity and cost of the coal feed system. Pressurizing the bed also permits an increase in the bed depth; this increases the transit time through the bed for small particles of coal and sorbent, thus increasing the efficiency of combustion and sorbent utilization. These points are presented in more detail in a companion report. ${ }^{2}$

The principal disadvantages of the system are the problems of particulate removal from the hot gases flowing to the gas turbine and the gas turbine bucket erosion and deposits caused by the small amounts of fine dust that eludes the particle separation equipment and reaches the turbine. This set of problems is the principal subject of this report.

\section{Operating Experience}

A brief survey of gas turbine operating experience pertinent to the development of coal-fired gas turbines is presented in this section to give perspective on the problems involved. Much more detalled information on salient points from this experience is presented in later sections. 


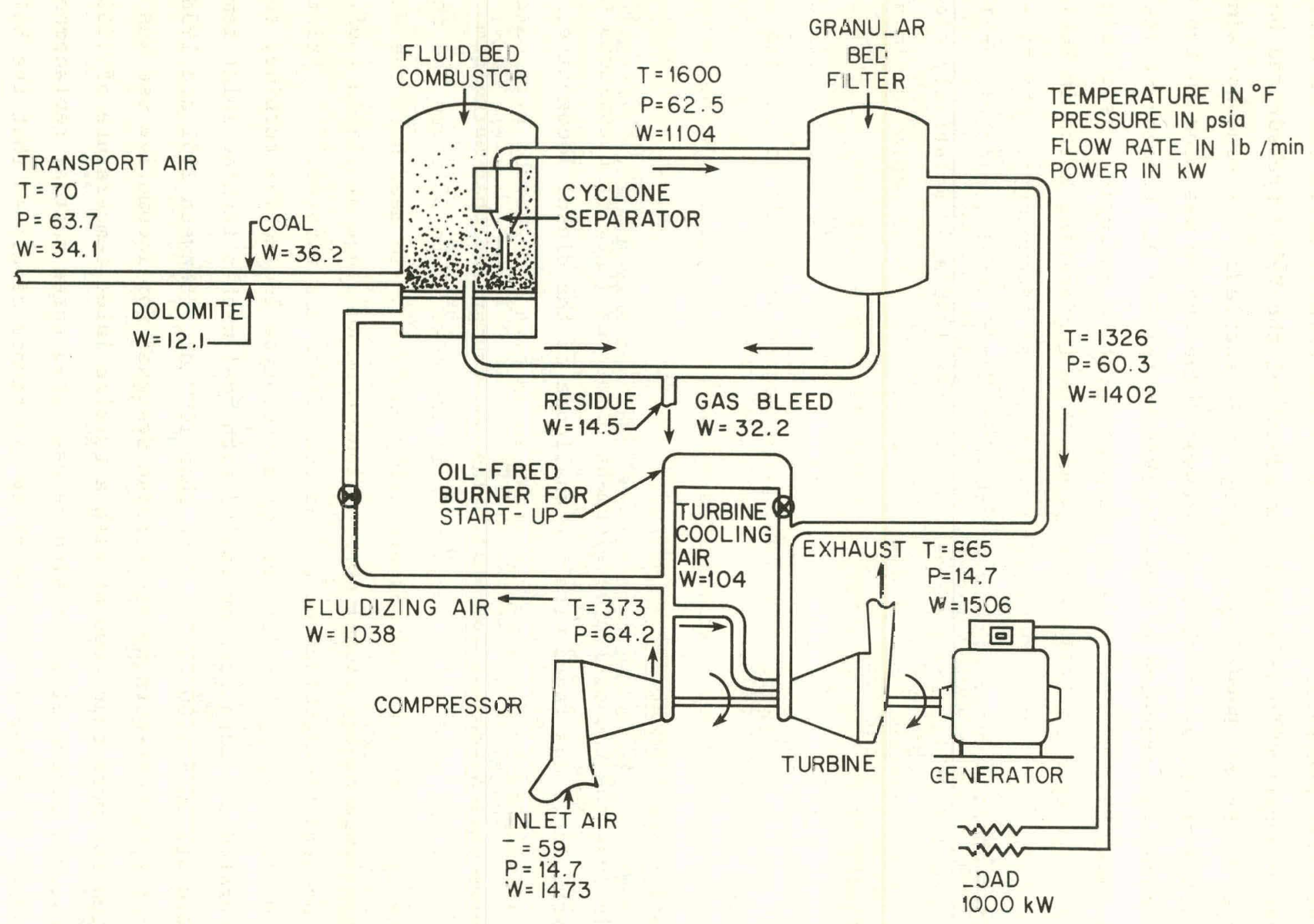

Fig. -. Flowsheet for a coal-fired open-cycla gas turbine. 
Early work on gas turbines

The first practical app.tication of a gas turbine drive for an axial compressor occurred in 1932 with the advent of the Velox pressurized boiler

developed by Brown, Boveri and Company of Switzerland. ${ }^{5}$ A somewhat similar application of the gas turbine compressor drive system was used in the Houdry catalytic cracking process in 1936 by the Sun Oil Company at its Marcus Hook, Pa., plant. ${ }^{6}$ The first power station employing gas turbines only was developed in 1939 by the Escher Wyss Engineering Works in Zurich, Switzerland. ${ }^{7}$ Utilizing the design and material technology of the aircraft jet engine developed during and after World War II, electric utilities began installing gas turbines in the late $1940^{\prime} \mathrm{s} .^{3}$ Relatively clean fuels, such as natural gas or distillate oils, have been employed almost exclusively as the energy supply for industrial gas turbines. Dirty fuels containing mineral constituents in sufficient quantities to have harmful effects on the turbine blading have proved to be difficult to utilize effectively.

\section{Locomotive Development Committee}

In 1944 the Locomotive Development Committee (LDC) of Bituminous Coal Research, Inc., was faced with the challenge of the diesel locomotive, which threatened to displace the steam locomotive and thereby eliminate the large railway market for coal. The LDC recognized that petroleum and natural gas production would peak in the next 20 to 30 years and that the energy market would depend primarily on coal. ${ }^{8}$ To meet both the shortterm challenge of the diesel and the long-term shortage of liquid fuel, the LDC pioneered the development of the coal-fired gas turbine. ${ }^{8-28}$ Prior to 1951, while awaiting the delivery of a prototype locomotive turbine, the LDC operated a Houdry turbine fueled with coal with a turbine inlet temperature of $750^{\circ} \mathrm{F}\left(400^{\circ} \mathrm{C}\right)$ for more than $1000 \mathrm{hr}$. Between 1951 and 1958, the prototype coal-burning gas turbine designed for locomotive use was operated for more than $4000 \mathrm{hr}$ with a turbine inlet temperature of $1250^{\circ} \mathrm{F}$ $\left(675^{\circ} \mathrm{C}\right)$, and severe blade erosion necessitated three partial replacements of blades. A review of the operating experience discloses that the bulk of the erosion and deposits occurred in the upper stages where the gas temperature was above $1050^{\circ} \mathrm{F}\left(565^{\circ} \mathrm{C}\right)$. The importance of gas temperature 
is indicated by the fact that the LDC operated the turbine with an inlet temperature of $1050^{\circ} \mathrm{F}\left(565^{\circ} \mathrm{C}\right)$ for approximately $500 \mathrm{hr}$ with negligible erosion and deposits. Blade erosion with a turbine inlet temperature of $1250^{\circ} \mathrm{F}\left(675^{\circ} \mathrm{C}\right)$ remained a major obstacle to the coal-burning turbine development when the LDC withdrew financial support of the program in 1959 , at which time the cumulative cust of the program in then-year dollars was about $\$ 5,500,000.9$

Concurrent1y, a similar effort in England and another modest effort in Canada were carried out with no greater success.?

\section{Union Pacific Railroad}

The Union Pactifc Raliroad, wishing to utilize its large coal reserves, commissioned Alco and General Electric to modify an oil-fired gas turbine engine so that it could be fired with coal and operated in a locomotive to carry the LDC program to its logical conclusion. ${ }^{30} \mathrm{Ex}-$ perience with this unit in rail service was disappointing; in the initial operation, the power fell off badly in $200 \mathrm{hr}$. Improvements were made in the cyclone separation system used to remove the dust, and a second test was run in which operation up to $400 \mathrm{hr}$ was obtained before the loss in power output became so severe that the test was terminated.

\section{Burcau of Mines}

After the termination of the LDC effort, the United States Bureall of Mines continued the investigation under a cooperative agreement with Bituminous Coal Research, Inc. ${ }^{31}$ The turbine and auxiliary equipment was transferred to the Bureau's Coal Research Center at Morgantown, W. Va. The Bureau arranged with General Electric for the design and construction of new blades for the turbine ${ }^{32}$ and by 1964 had completed testing of the turbine at an inlet temperature of $1250^{\circ} \mathrm{F}\left(675^{\circ} \mathrm{C}\right)$ with a total of approximately $2000 \mathrm{hr}$ of running. The new blade design gave improved resistance to erosion as compared to those tested in the LDC program. The estimated life of the rotor blades was 20,000 to $30,000 \mathrm{hr}$; the stator blades had an estimated life of only 5000 to $7500 \mathrm{hr} .{ }^{31}$ 
Australian program

Concurrently with the coal-fired gas turbine programs in the United States, an investigation in Australia of the problems of firing a gas turbine with coal was initiated in 1948 by the Aeronautical Research Laboratories (ARL) at a total cost in then-year dollars of about $\$ 1,500,000 .{ }^{3-36}$ In the earlier stages of the ARL effort, the major thrust of the program was directed toward the problems of coal pulverizing and handling, high-intensity combustion and combustor development, and ash fouling and erosion. Considerable progress had been made on the problems of handling, and burning coal for use as fuel in gas turbines when 4 tons of Victorian brown coal were burned satisfactorily in the LDC experimental Houdry gas turbine system in $1951 .^{34}$ Rig experiments on a coal-fired aircraft supercharger gave little evidence of erosion but did indicate an ash deposition problem. Inasmuch as the supercharger blading was aerodynamically crude and it was believed that the rate of ash deposition would depend upon the blade design, a nonrecuperative gas turbine unit consisting of a 13-stage compressor, a 2-stage compressor turbine, and a 2-stage power turbine was obtained and commissioned in 1958 . The system was operated for approximately $400 \mathrm{hr}$ at an inlet temperature of $1200^{\circ} \mathrm{F}\left(650^{\circ} \mathrm{C}\right)$ on various grades of Australian coal between 1959 and 1963. Ash deposition and erosion remained a problem throughout this phase of the test program.

In 1963, the 2-stage compressor drive turbine was replaced with a 3-stage turbine designed to operate with a gas velocity of 800 fps (244 $\mathrm{m} / \mathrm{sec}$ ) compared to the $1200 \mathrm{fps}(366 \mathrm{~m} / \mathrm{sec}$ ) in the 2-stage machine. The redesigned machine was commissioned in 1969, and testing with coal was completed in 1970 with a total running time of approximately $125 \mathrm{hr}$ with a turbine inlet temperature of about $1200^{\circ} \mathrm{F}\left(650^{\circ} \mathrm{C}\right)$. The blades remained clean throughout the test except for a film of ash on the first-row stators. The estimated life made on the basis of only $125 \mathrm{hr}$ of testing was 30,000 to $50,000 \mathrm{hr}$ for the rotor blades and 25,000 to $50,000 \mathrm{hr}$ for the stator blades. 33 


\section{Catalytic-cracking units}

The use of gas turbines to provide combustion air to burn out the coke that accumulates on the $\mathrm{Al}_{2} \mathrm{O}_{3}$-based pellets used as the catalyst in petroleum refinery catalytic-cracking units ${ }^{6}$ was confined to operation with turbine inlet temperatures largely below $800^{\circ} \mathrm{F}\left(425^{\circ} \mathrm{C}\right)$ until the $1950^{\prime}$ 's and hence little or no net useful power was obtained.

In 1950, the Elliott Company made the first sophisticated effort to recover power from a petroleum catalytic-cracking unit by introducing a higher inlet temperature turboexpander into the flue gas stream directly downstream of the regenerator. ${ }^{37}$ Because there was nothing ahead of the expander to reduce the particulate level, the performance deteriorated rapidly and by the end of $750 \mathrm{hr}$ the turbine was virtually useless.

A review of the Elliott Co. experience and the LDC work indicated that not only should the particulate content of the gas be reduced but every effort should be made to keep it uniformly dispersed in the gas stream to avoid severe local erosion, particularly at the roots and tips of the blades. This led to the decision to use a single-stage turbine with a long straight inlet passage. This, together with extensive development work on particle separators, led th a test with three etagec of cyclone separators conducted in 1957 by the Shell Development Com-pany. ${ }^{37,38}$ After $4000 \mathrm{hr}$ of continuous operation, inspertion of the blading revealed no serious erosion. Commerrial installation of thoco units began in 1963 and was extended to eight refineries by 1973. The total power recovery capacity of the eight installations is approximately $62 \mathrm{MW}$ with an estimated turbine life of 25,000 to $40,000 \mathrm{hr} \cdot{ }^{37-39}$ These units operate with a turbine inlet temperature of about $1100^{\circ} \mathrm{F}\left(594^{\circ} \mathrm{C}\right)$. Turbine inlet temperatures as high as $1150^{\circ} \mathrm{F}\left(620^{\circ} \mathrm{C}\right)$ have hepn used with Incone1 $\mathrm{X}$ blades coated with tungsten carbide to give a turbine life of two to three years. ${ }^{39}$ Extensive experience w1th these units indicates that erosion can be kept to a tolerable level with two stages of cyclone separators followed by a third-stage multicyclone (which gives a particulate loading of $\sim 100 \mathrm{ppm}^{*}$ ) for operation at turbine inlet temperatures up ${ }^{*} 1 \mathrm{ppm}=1.22 \mathrm{mg} / \mathrm{m}^{3}=0.0345 \mathrm{mg} / \mathrm{ft}^{3}=0.00054 \mathrm{grain} / \mathrm{ft}^{3}$. 
to $\sim 1150^{\circ} \mathrm{F}\left(620^{\circ} \mathrm{C}\right)$ if a single-stage turbine is used with excellent inlet conditions. ${ }^{37-44}$

Gas turbines operated on low-Btu gas from blast furnaces and gasifiers

A substantial amount of experience has been obtained in the United States and in Europe with gas turbines operating on low-Btu gas from blast furnaces with turbine inlet temperatures around $1.350^{\circ} \mathrm{F}\left(730^{\circ} \mathrm{C}\right)$. After extensive testing of hot-gas cleanup equipment, it has been found best to cool this gas and clean it with a two-stage wet scrubber and/or an electrostatic filter prior to burning it in a combustion chamber ahead of the turbine. ${ }^{4-50}$ The particulate content in the gas fed to the turbine is commonly kept below $1 \mathrm{ppm}$ by weight. The same approach and requirement have been imposed on the low-Btu gas supplied from Lurgi gasifiers to the gas turbine of the combined-cycle plant at Lünen, Germany. ${ }^{51}$

A typical example of turbine performance with blast furnace gas is a Sulzer gas turbine employed for supercharging a blast furnace at the Hainaut-Sambre works in Belgium. The turbine has produced $7500 \mathrm{~kW}(\mathrm{e})$ with a gas inlet temperature of $1310^{\circ} \mathrm{F}\left(710^{\circ} \mathrm{C}\right)$ since 1955 . Erosion of the first-stage turbine buckets progressed to the point where some loss in efficiency occurred after $81,000 \mathrm{hr}$ of operation, at which point these blades were replaced. However, the second- and chird-stage blades were still in satisfactory condition after $136,000 \mathrm{hr}$ of operating time. ${ }^{52}$

\section{1-burning gas turbines}

In the United States, commercial specifications for conventional gas turbines limit the particulate content to no more than $1 \mathrm{ppm}$ by weight and the maximum particle size to $10 \mathrm{~lm}$ for gas turbine applications, whether for operation on fuel oil or in dusty environments. ${ }^{53,54}$ Severe erosion has occurred in both industrial and utility gas turbines as a consequence of dust in the air entering the compressor; hence air filters are normally required. 
Cascade tests with fluidized beds at BCURA

The British Coal Utilization Research Association, Ltd. (BCURA), has devoted practically all its effort since 1971 to research and development work on fluidized-bed combustion and gasification. Design studies indicate that there are major advantages to pressurizing the fluidized-bed combustor with a gas turbine. ${ }^{2,55}$ There are indications that the ash from a fluidized bed will be less erosive than that from a pulverized coal burner. Experiments at BCURA with a pressurized fluidized-bed coal combustion system have included a number of runs in which the hot gases leaving the bed at about 6 atm have been directed through a cascade of bladeo representing a turbine nozzle. ${ }^{55,58}$ Tests run with inlet gas temperatures of around $1550^{\circ} \mathrm{F}\left(843^{\circ} \mathrm{C}\right)$ showed rclatively 11 Llle in the way of deposits or erosion for a period of $500 \mathrm{hr}$ of operation. For comparison, a similar experiment conducted by the LDC as a part of the 1421-hr turbine test also gave negligible deposits and erosion at $1250^{\circ} \mathrm{F}$ $\left(677^{\circ} \mathrm{C}\right)$. The most recent BCURA test of record was carried out with an inlet gas temperature of 1600 to $1700^{\circ} \mathrm{F}\left(870-925^{\circ} \mathrm{C}\right)$. This yielded appreciable deposits and little erosion, but photomicrographs indicate appreciable corrosion. In general, the corrosion wds cumparable to that found with ojl-fired gas turbines operating al the same temperature, with comparable amounts of sulfur in the fuol, but the depusles were substantially greater.

The results of the BCURA tests with blade cascades are encouraging but not definitive. The particulate content of the gas entering the test section ran about $250 \mathrm{ppm}$ by weight with $90 \%$ of the particles smaller than $1.0 \mu \mathrm{m}$.

\section{Combustion Power Company}

The Cumbustion l'ower Cumpany began work on coupling a gas turbine to a fluidized-bed burning solid wastes in 1969 and subsequently shifted in 1974 to operation with coal. 57-60 By 1976, the unit had accumulated approximately $600 \mathrm{hr}$ of turbine operation al an linlet temperature of approximately $1400^{\circ} \mathrm{F}\left(760^{\circ} \mathrm{C}\right)$. The hot-gas cleanup system for these tests was operated at temperatures of 1500 to $1600^{\circ} \mathrm{F}\left(815-870^{\circ} \mathrm{C}\right)$ with cooling downstream of the last stage of particle separation so as to not exceed 
the design turbine inlet temperature of $1450^{\circ} \mathrm{F}\left(788^{\circ} \mathrm{C}\right)$. The hot-gas cleanup devices used in this series of tests consisted of tangential entry cyclones and 6- and 3-in. (15.2- and 7.6-cm) multicyclones. In each test the multicyclones became ineffective after a few hours of operation owing to ash plugging which resulted in heavy fouling and erosion in the turbine. Subsequent work has been directed toward the use of granular bed filters. ${ }^{6} 0$

\section{Turbosupercharged fluidized-bed furnaces for steam generators}

The extensive experience outlined above clearly indicates that coalburning gas turbines have always given serious trouble with erosion and deposits when operated with turbine inlet temperatures above $\sim 1200^{\circ} \mathrm{F}$ $\left(650^{\circ} \mathrm{C}\right)$ but have been relatively free of these difficulties if the inlet temperature is below $\sim 1050^{\circ} \mathrm{F}\left(565^{\circ} \mathrm{C}\right)$. This experience is consistent with basic considerations of metal erosion rates as a function of temperature and the softening point of the lower-melting-point constituents of coal ash. ${ }^{61,62}$ In view of this, it has been proposed at ORNL that a lowtemperature gas turbine be employed to supercharge a fluidized-bed furnace in the same manner as Bucchi turbochargers.are employed to supercharge diesel engines. ${ }^{62}$ In fact, production units for large diesels might be used. There would be no attempt to obtain any net electrical power; the objective would be simpl.y to raise the furnace pressure and thus improve combustion conditions and reduce capital costs.

\section{Accumulated Costs and Running Time}

The expenditures in the U.S. and Australia for the development of the open-cycle coal-fired gas turbine for the 1945-75 period are summarized in Table 1, and the operating hours accumulated at various turbine inlet temperatures are given in Table 2. The operating experience with coal-fired gas turbines under the Locomotive Development Committee is summarized in Table A.5 (see appendix) to show the effects of turbine inlet temperature and hot-gas particulate content on turbine bucket erosion and deposits. The cumulative costs and turbine operating time are shnwm in Fig. 2 for the period 1945-75. Inspection of Fig. 2 shows a 
Table 1. Expenditures in the U.S. and Australia for open-cycle coal-fired gas turbine development during the period 1945-1975 $\left(\$ \times 10^{3}\right)^{\alpha}$

\begin{tabular}{|c|c|c|c|c|c|c|c|}
\hline & $1945-50$ & $1951-55$ & $1956-60$ & $1 \subseteq 61-65$ & $1966-70$ & $1971-75$ & $1945-75$ \\
\hline $\begin{array}{l}\text { Locomotive Development Committee } \\
\text { U.S. Bureau of Mines } \\
\text { Union Pacific Railroad } \\
\text { Aeronautical Research Laboratories } \\
\text { Petroleum Refineries } \\
\text { Combustion Power Company }\end{array}$ & $53^{b}$ & 3000 & $\begin{array}{r}2000 \\
500^{\circ} \\
236 \hat{b} \\
1000^{b}\end{array}$ & 4500 & $\begin{array}{l}500 \\
780 \\
500\end{array}$ & 3000 & $\begin{array}{r}5,500 \\
5,000 \\
500 \\
1,625 \\
1,000 \\
3,500\end{array}$ \\
\hline Total & 550 & 3075 & 3736 & 4945 & $i 780$ & 3039 & 17,125 \\
\hline
\end{tabular}

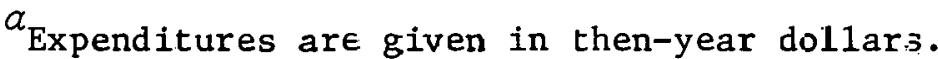

$b_{\text {Estimated. }}$

${ }^{c}$ The Combustion Power Conpany turbine expenditures were taken as $25 \%$ af their yearly costs. 
Table 2. Open-cycle coal-fired gas turbine operating hours during the period 1945-1975

\begin{tabular}{|c|c|c|c|c|c|}
\hline & \multicolumn{5}{|c|}{$\begin{array}{c}\text { Turbine inlet temperature } \\
{\left[{ }^{\circ} \mathrm{F}\left({ }^{\circ} \mathrm{C}\right)\right]}\end{array}$} \\
\hline & $\begin{array}{l}<1000 \\
(538)\end{array}$ & $\begin{array}{l}1000-1100 \\
(538-593)\end{array}$ & $\begin{array}{l}1101-1250 \\
(593-677)\end{array}$ & $\begin{array}{c}1251-1450 \\
(677-738)\end{array}$ & $\begin{array}{l}>1450 \\
(788)\end{array}$ \\
\hline Locomotive Development Committe & 1250 & 478 & 3281 & & \\
\hline U.S. Bureau of Mines & & & 2963 & & \\
\hline Union Pacific Railroad & & & $\sim 500$ & . & \\
\hline Aeronautical Research Laboratories & & & 428 & & \\
\hline Petroleum Refineries & & & 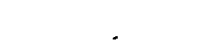 & & \\
\hline Combustion Power Company & & & & 591 & \\
\hline Tota1 & 1250 & 478 & .7172 & 591 & 0 \\
\hline
\end{tabular}




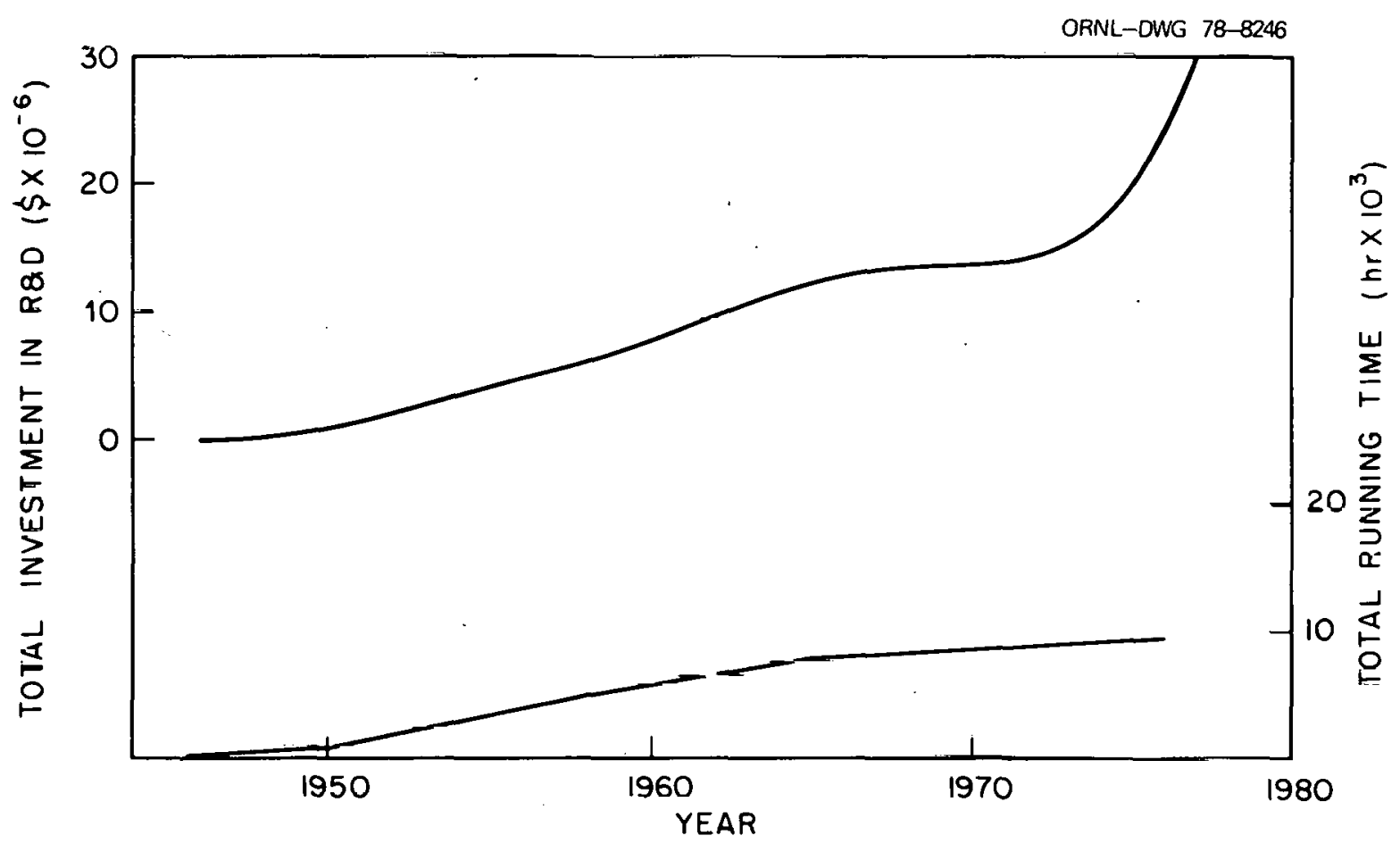

Fig. 2. Research costs and operating time for open-cycle coal-fired gas turbines during the period 1945-1975.

total expenditure in then-year dollars of approximately $\$ 17,000,000$ and a total operating time of approximately $9500 \mathrm{hr}$ during the 30-year period.

\section{RECOMMENDED DEVELOPMENT PROGRAM}

The two key developmental problems of the open-cycle coal-fired gas turbine are turbine bucket erosion and deposils, both of which arc heavily dependent on the temperature of the combustion gascs entering the turbine. The hardness of turbine bucket alloys decreases rapidly with an increase in turbine inlet temperature abuve abuit $1110^{\circ} \mathrm{F}\left(600^{\circ} \mathrm{C}\right)$, thuc making turbine bucket erosion a serious problem for particulate contents of over $100 \mathrm{ppm}$ at $1110^{\circ} \mathrm{F}\left(600^{\circ} \mathrm{C}\right)$ or over 1 ppm at a turbine inlet temperaturc of $1560^{\circ} \mathrm{F}\left(850^{\circ} \mathrm{C}\right)$. Firther, a small percentage of the ash consists of low-melting glasses (e.g., sulfates) that are sticky at temperatures down to about $1110^{\circ} \mathrm{F}\left(600^{\circ} \mathrm{C}\right)$ and tend to adhere to surfaces on which they impact. The resulting film acts like "flypaper" and accumulates hard 
ceramic deposits of higher-melting-point ash particles. Extensive experience with hot-gas cleanup equipment indicates that it is difficult indeed to reduce the particulate content to $10 \mathrm{ppm}$ and that excessive deposits are formed even at this level if the turbine inlet temperature exceeds about $1100^{\circ} \mathrm{F}\left(594^{\circ} \mathrm{C}\right)$. In fact, commercial gas turbine specifications normally limit the ash content of the fuel oil and the particulate content of the inlet air to the equivalent of no more than $22 \mathrm{ppm}$ in order to limit deposits to an acceptable level.

Efforts to develop suitable hot-gas particle removal equipment are under way and should be continued. However, since past experience is not encouraging, commitments to build gas turbine systems (other than small experimental units) should be deferred pending the demonstration on a small scale of an economical, promising, long-lived, hot-gas cleanup system operated with a fluidized bed that burns a coal having a representative ash composition.

Extensive experience with coal-fired gas turbines, gas turbines operating on blast furnace gas, conventional gas turbines operating with dusty inlet air, and gas turbines used in conjunction with catalytic-cracking units in petroleum refineries indicates that it is doubtful that the particulate content of the products of combustion from the fluidized-bed coal combustion system can be reduced at a reasonable cost to a level that will permit gas turbine operation with inlet temperatures much above $1110^{\circ} \mathrm{F}$ $\left(600^{\circ} \mathrm{C}\right)$. However, the same body of experimental experience indicates that satisfactory turbine life could be obtained with the products of combustion from a fluidized-bed coal combustion system for turbine inlet temperatures below $1050^{\circ} \mathrm{F}\left(565^{\circ} \mathrm{C}\right)$; this can be done with the state-of-theart particulate removal systems used in catalytic-cracking units, that is, two stages of cyclone separators followed by a single-stage multicyclone separator to supply a single-stage turbine with gas having a particulate content in the range of less than $100 \mathrm{ppm}$. Although the low turbine inlet temperature would give only enough power to drive the compressor and hence provide only a small improvement in thermal efficiency, pressurizing the furnace would reduce its capital cost and the cost and complexity of the coal feed system relative to atmospheric-pressure fluidized beds. It 
would also increase the efficiency of both combustion and sorbent utilization and give improved system control characteristics.

To demonstrate the use of a turbine-compressor unit supercharging a pressurized coal-fired fluidized-bed combustor, attention should be directed toward such a system with the furnace operating at approximately 4 atm with flue gas cooling in the steam generator sufficient to givc a turbine inlet temperature in the 1000 to $1050^{\circ} \mathrm{F}\left(546-565^{\circ} \mathrm{C}\right)$ range. Operating under these conditions, the turbine erosion, corrosion, and deposit problems should become secondary considerations. This would give a test bed for the solution of the other problems associated with pressurized tluidized-bed combistion. Pruvisiun fur inicorporating advanced particulate separation systems in the overall design of the experiment should be made to allow higher turbine inlet temperatures to be employed if they become available after other components of the overall design have been adequately developed.

\section{PRINCIPAL PROBLEMS AND PARAMETERS}

The principal problems associated with the open-cycle coal-fired gas turbine are erosion and corrosion of the turbine blades, the deposition of solids on the blades in sufficient quantity to ubstruct the gas flow passages, the capital costs of the turbine and associated equipment, the operating life, and the reliability and maintenance problems. These in turn depend heavily on the detailed design of the turbine, the particulate removal equipment, the coal combustion system, and the overall equipment layout. Note that full-scale experience in both experimental and commercial installations is available for an assessment of the coal-fired gas turbine for use in advanced power generation systems. ${ }^{6-60}$ Thus, there is no question that an advanced power generation syscem empluylny an upencycle coal-fired gas turbine can be built and operated for short periods. The key questions are concerned with the detailed costs for a full-scale commercial system 1ncluding the effects of reliability and maintainability, particularly the effectiveness of hot-gas cleanup equipment and the consequent limitations on the useful life of the turbine blading imposed by erosion and deposits. 
Erosion

Some excellent analytical and experimental studies of the basic mechanism of erosion of turbine buckets by small particles have been carried out in recent years. ${ }^{63-75}$ These studies indicate that the erosion rate depends on the type of particle, size of particle, the angle of incidence relative to the surface on which it impinges, the velocity of impingement, the particulate content of the gas stream, and the physical properties of the surface subject to erosion. The effects of these are discussed in the following sections.

\section{Effects of particle character and angle of incidence}

Extensive tests have been carried out with extremely different particle types, ranging from angular grains of silica sand to water droplets. Both analyses and experiments indicate that the damage mechanism is fundamentally different for these particle types. The maximum damage caused by a particle of sand occurs at an incident angle of approximately 20 to 35 deg relative to the surface, and the resulting damage appears to be primarily a scoring of the surface. ${ }^{63-71}$ With liquid droplets, on the . other hand, the maximum damage occurs when the angle of incidence of the particle is $90 \mathrm{deg}$, and the form of the damage appears to be mainly plastic indentation of the blade material and subsequent failure by low-cycle fatigue if the material is soft and ductile. In hard materials, the damage appears to be similar to that in the races of ball bearings; that is, high shear stresses are induced below the surface by the impact, and fatigue causes material to spall off producing pits. ${ }^{72-74}$

Further, liquid droplet erosion in wet vapor turbines also differs in a fundamental way from that in gas turbines in that the micron-size droplets of moisture that form in the wet vapor do not cause erosion directly. Rather, they impinge on stator vanes, the resulting liquid film is carried to the trailing edge, and large droplets are then shed from the trailing edges of stator blades. ${ }^{73,75}$ It is these large droplets that are responsible for erosion in the rotor. This is partly because a liquid film tends to form on the surface of the rotor blade and act as a cushion to protect the blade from very small droplets whose diameter is not many 
times greater than the thickness of the liquid film. As a consequence, the measures taken by both the designer and the operator to cope with turbine bucket erosion in wet vapor turbines are quite different from those in gas turbines that ingest solid particles.

Hoy ${ }^{5}$ suggested that the erosion of blades in a gas turbine coupled to a fluidized-bed coal combustion chamber might be much less serious than if a pulverized coal burner were employed. The ash formed in a fluidized bed tends to be soft and friable because it is formed well below the fusion point, whereas the ash particles in a pulverized coal burner are vitreous cinders that are formed well above the fusion point of the ash and subsequently chilled by the secondary air. Evidence supporting this contention can be seen by examining the results of the first two tests of the Ruston and Hornsby "TA" turbine by ARL. ${ }^{33}$ In these tests (described in the appendix), the direct coal-fired machine was operated with and without a cyclone upstream of the turbine. Without the cyclone a heavy deposit of a dense, sintered materiai was formed on the leading edges of the stator blades. With the cyclone in place the hard sintered deposit was no longer in evidence and had been replaced by a lightly bonded, soft, friable ash. The inclusion of the ash separator resulted in a reduction in the erosion rate in the turbine by a factor of approximately 50 . Perhaps a third of this reduction might be accounted for by the reduction in the particulate loading. The additional reduction probably resulted from the change in the physical characteristics of the particulates that were not removed by the cyclone separator. On the other hand, microscopic examination of particles in the hot-gas stream from a fluidized bed has shown a high incidence of angular grains that one would expect to be abrasive, and about $20 \%$ of the total weight of the particles escaping from the cyclones has been found to be $\mathrm{SiO}_{2}, 59$

\section{Effects of blade hardness}

The choice of blade material influences the erosion rate. Figure 3 shows the effect of metal target hardncss erosion rate and supports one's intuitive feeling that increasing the hardness of the blades should reduce the erosion rate. It also supports Hoy's thesis that the softer particles from a fluidized bed should be less erosive than ash from conventional 


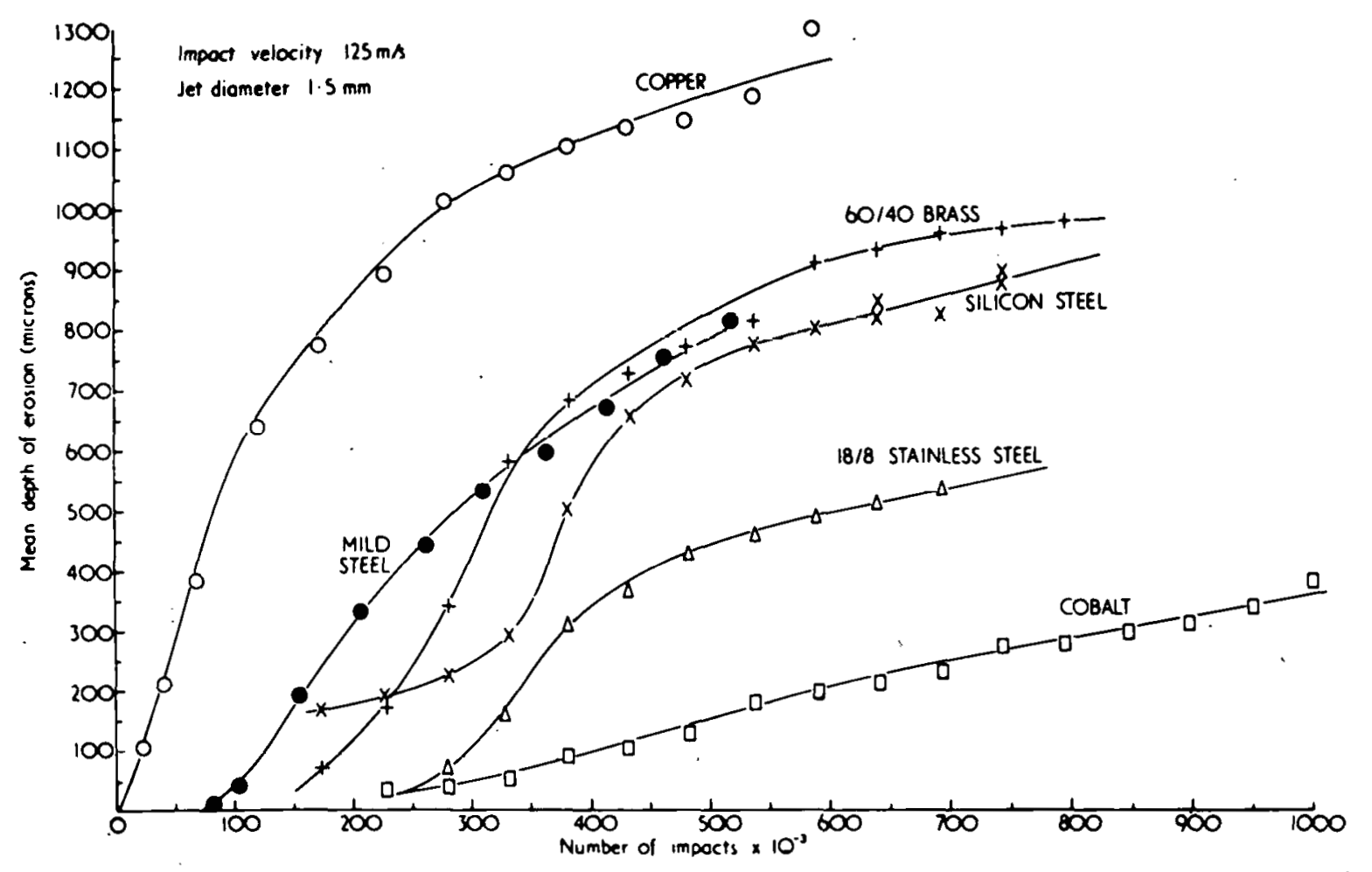

Fig. 3. Erosion as a function of the number of liquid droplet impacts on typical metals and alloys (Ref. 74).

burners. Another good indication of the effects of temperature on Lurbine blade erosion is given by Fig. 4, taken from Ref. 69. That study, as summarized in Fig. 4, shows good correlation between the erosion rate and the ratio of the melting point of the blade alloy to its modulus of elasticity. A review of data on the lateer parameter for $\mathrm{Fe}-\mathrm{Cr}-\mathrm{Ni}-\mathrm{Co}$ alloys indicates that dropping the temperature from 1600 to $1000^{\circ} \mathrm{F}\left(871-538^{\circ} \mathrm{C}\right)$ increases the modulus of elasticity by 30 to $60 \%$. Figure 4 indicates that such an increase in the modulus should reduce the erosion rate by a factor of about 10 .

Experience with steam turbines has indicated that a very hard alloy such as Stellite is exceptionally resistant to erosion by wet vapor, and experience with hard nickel-chromium alloys in gas turbines is consistent with the steam turbine experience. ${ }^{31,74}$ Inasmuch as the high nickelchromium alloys are also exceptionally good from the high-temperature 


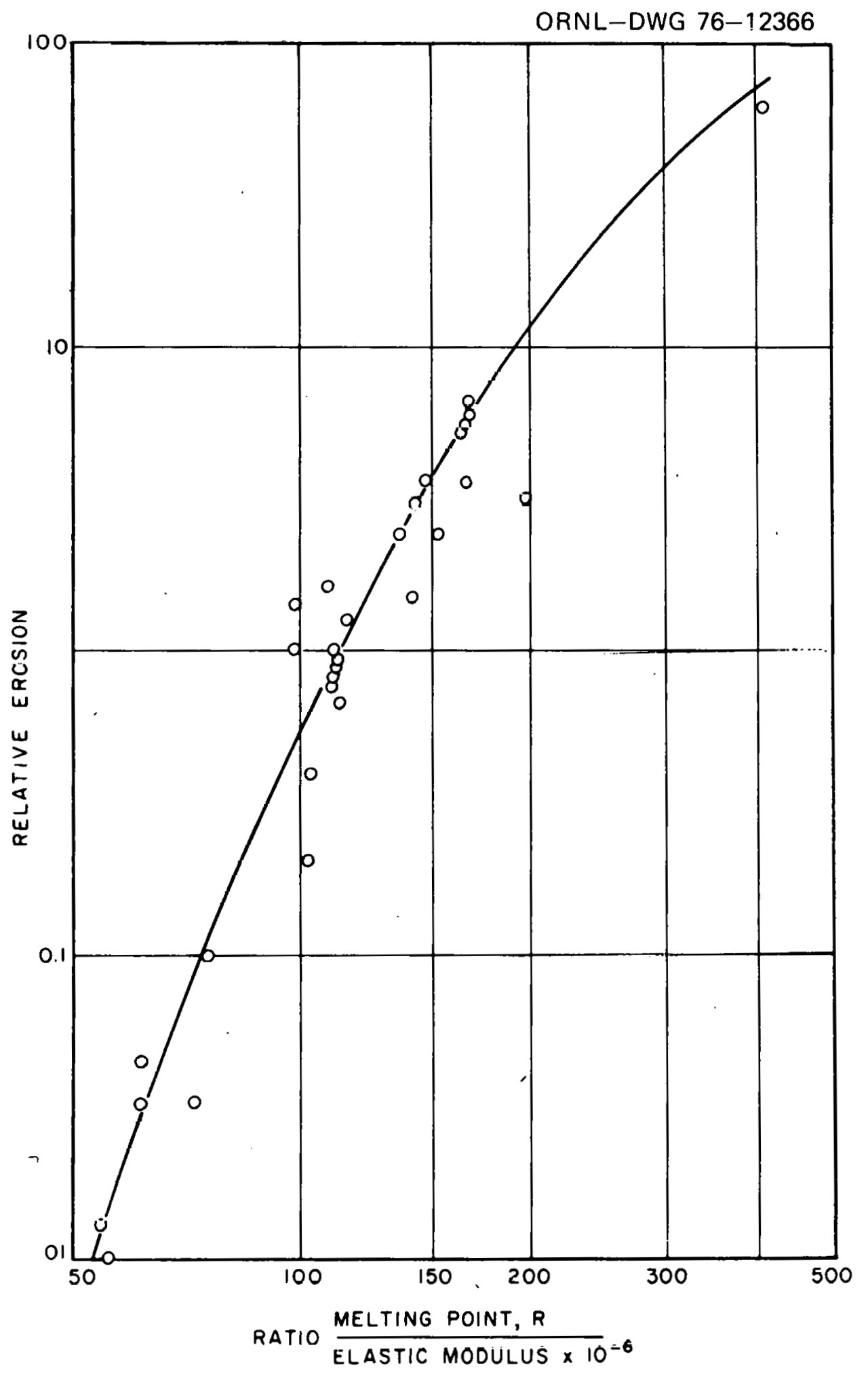

Fig. 4. Correlation of erosion with ratio of melting point to elastic modulus (Ref. 69). 
strength standpoint, and hence commonly used in gas turbine blades, the usual materials of construction are about as erosion resistant as one might find.

It should be noted that in the work carried out by the Bureau of Mines with the turbines from the Locomotive Development Committee program, the use of titanium carbide inserts near the blade roots essentially eliminated erosion with no changes in the particulate content of the gas or in the turbine wheel tip speed, and that flame spraying blade surfaces with tungsten carbide has increased the life of turbines in cat cracker service. ${ }^{31,39}$ This supports the intuition that increasing the turbine blade hardness will reduce the erosion rate.

\section{Effects of particle size}

The effects of particle size on the erosion rate are indicated by Fig. 5. These data were obtained with silica particles. ${ }^{4}$ Somewhat similar data for helicopter and ground-based engines ${ }^{63}$ (Fig. 6) indicate that

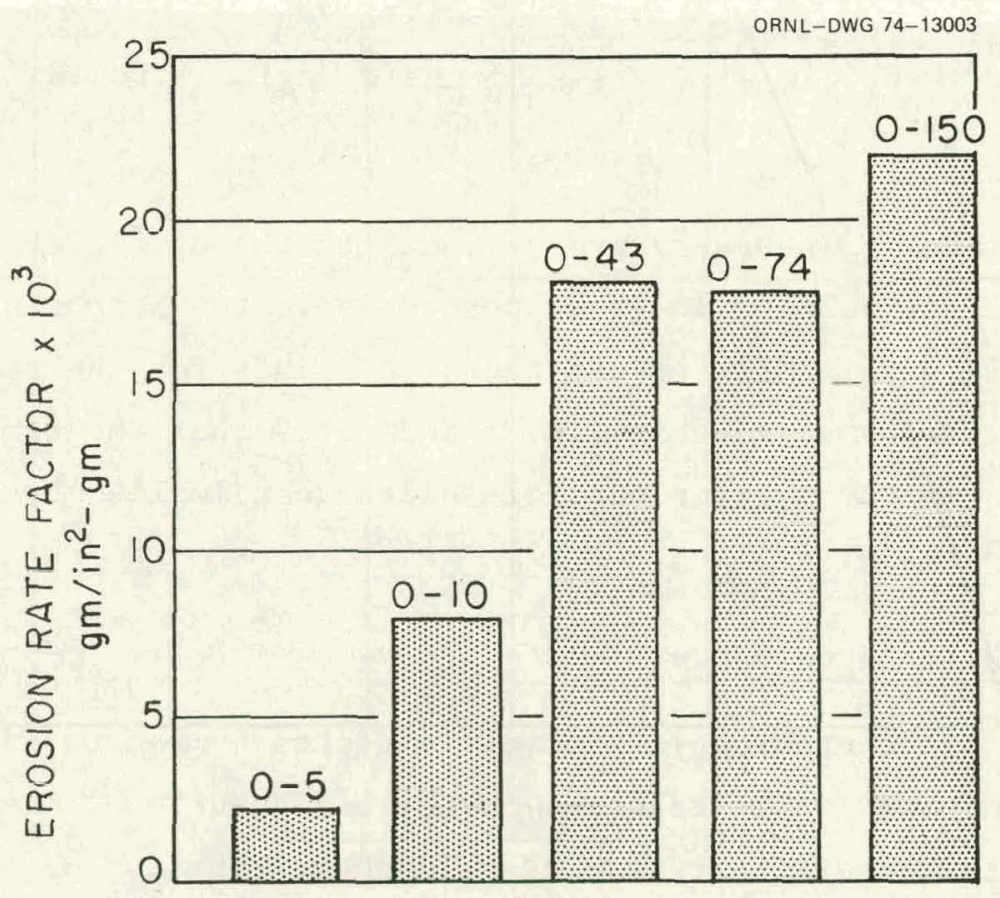

Fig. 5. Erosion loss vs dust particle size range for pearlitic C-1050 steel with $375-\mathrm{ppm}\left(0.013-\mathrm{g} / \mathrm{ft}^{3}\right)$ dust concentration, 850-fps afr-stream velocity, 40-deg apparent impact ang1e (Ref. 64). 


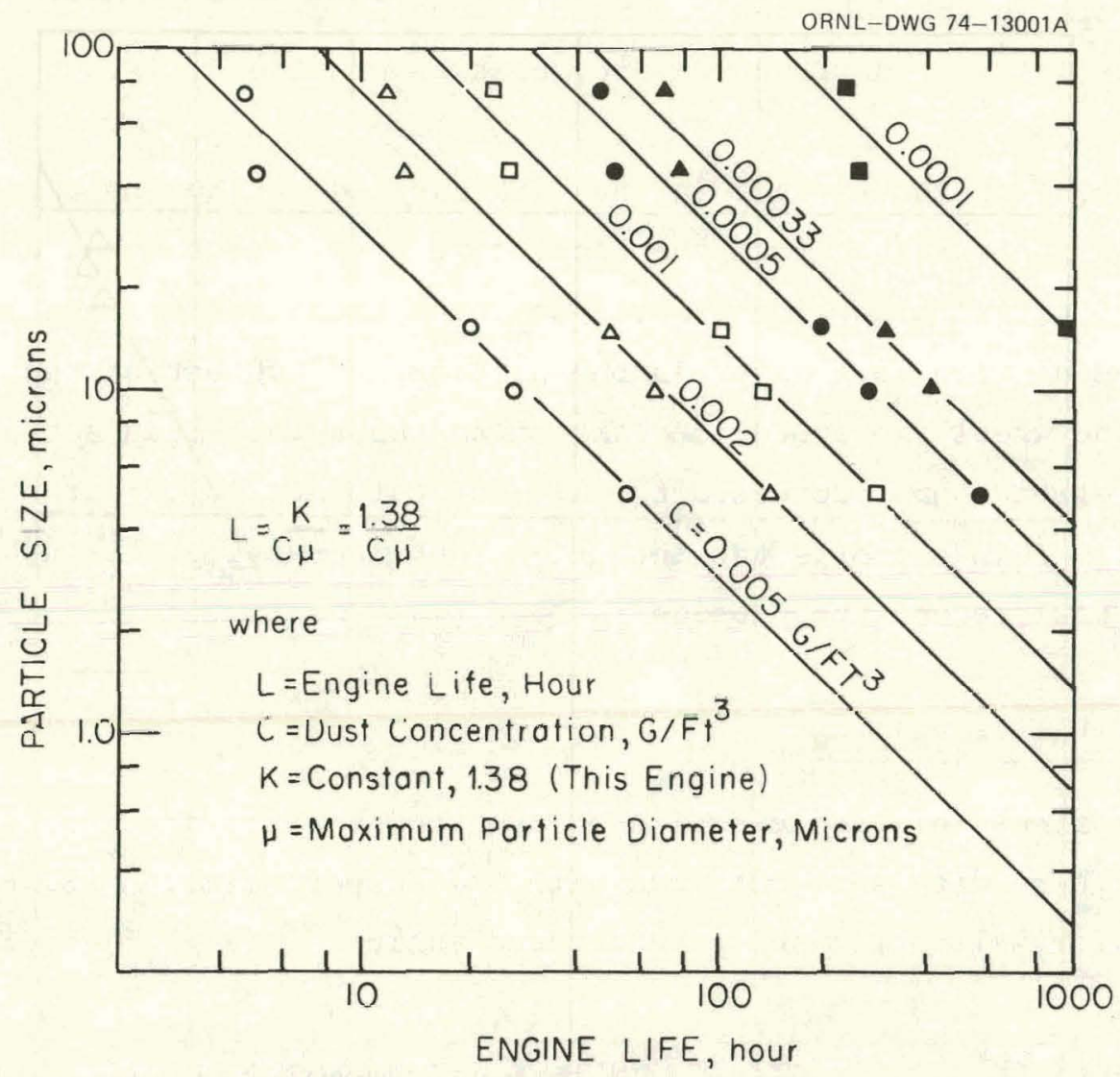

Fig. 6. Particle size vs usable safe engine life (Ref. 63).

the erosion rate is inversely proportional to the particle size for a given particulate content in grams per cubic foot. Note that these curves were extrapolated linearly beyond the data points for the smallest particle size (about $\zeta \mu \mathrm{m}$ ) and that Fig. 5 indicates that the damage would be less serious for the smaller particle sizes than implied by the curve extrapolatiuns of Fig. 6.

\section{Effects of particle velocity}

Turbine blade erosion is strongly affected by the particle velocity and the impingement angle relative to the blade surface. Experiments indicate that the erosion rate varies as a power function of the relative velocity (Fig. 7), which suggests that the erosion problem can be drastically eased by reducing the design tip speed of the turbine. ${ }^{63,64}$ This thesis has been validated by the Australian work, where a reduction in 


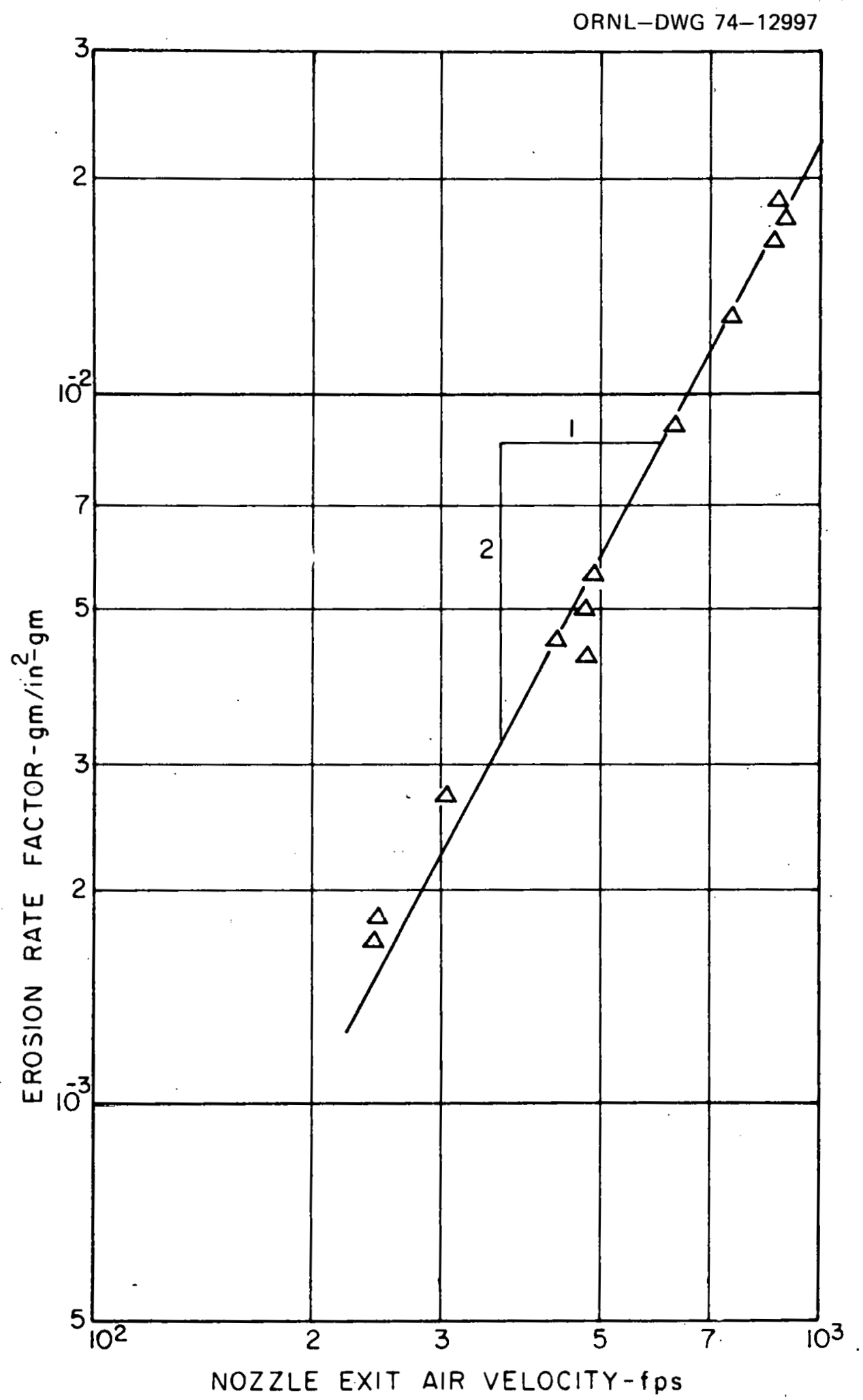

Fig. 7. Erosion loss vs airstream velocity with tempered C-1050 steel for $375-\mathrm{ppm}\left(0.013-\mathrm{g} / \mathrm{ft}^{3}\right)$ dust concentration; $0-74 \mu \mathrm{m}$ silica flour; 40-deg apparent impact angle (Ref. 64). 
the relative velocity from 1100 to 800 fps essentially eliminated erosion. ${ }^{33}$ A reduced tip speed has also been found helpful in expander turbines for catalytic-cracking unit service. ${ }^{39}$ However, this approach has the disadvantage that the work output per stage varies as the square of the velocity; hence, cutting the velocity from 1100 to $800 \mathrm{fps}$ would, in effect, require increasing the number of stages by a factor of about 2 , thus increasing the cost of the turbine by nearly as great a factor.

\section{Effects of particulate content of the gas stream}

The rate of erosion appears to be directly proportional to the quantity of particulate matter passing through a turbine for a given particle size and character. This is, of course, as one would expect.

\section{Deposits}

Every effort to operate a gas turbine on the products of combustion of coal and/or solid wastes has met with difficulties with the buildup of deposits, particularly in the stator blades. $24-27,31,33,58$ In cases where no effort has been made to remove the ash particles between the combustor and the turbine, the deposit buildup has forced the turbine out of service (in one case in as little as $2 \mathrm{hr}$ ) as a consequence of a severe loss of power or a reduction in airflow to the point where compressor surge was imminent. ${ }^{3}$ Thus, the first step ordinarily taken has been to remove as much of the dust as possible with cyclone separators or some type of filter. A second method of reducing deposits is to reduce the turbine inlet temperature, which results in a reduction in the turbine work and thereby limits the degree to which this technique can be utilized.

\section{Buildup of engine deposits}

The character of the deposits formed in an engine depends on the type of dust. In military gas turbines, where the dust consists primarily of particles of silica and feldspars, the melting or softening point is sufficiently above the operating temperature that the dust does not tend to 
stick, and deposits build up only in regions where local aerodynamic conditions favor deposition. The hot ash in coal-burning gas turbines presents a quite different set of problems. In the direct coal-fired operation of turbines in the LDC, ÁRL, and the United States Bureau of Mines programs, the pulverized coal was burned in near-stoichiometric proportions to give flame temperatures approaching $2500^{\circ} \mathrm{F}\left(1370^{\circ} \mathrm{C}\right)$; the products of combustion were then cooled by mixing with secondary air to give the desired turbine operating temperature. The volatile alkali metal sulfates formed during the combustion tended to condense and stick to the blades where they formed a coating to which other ash particles tended to stick and agglomerate, with the alkali metal sulfates acting as bonding agents. ${ }^{31}$

An excellent insight into the effects of both low-melting constituents in the ash and turbine inlet temperature on ash deposits in the turbine was obtained in Australia in a test rig designed to simulate turbine conditions. $^{33}$ Tests were carried out with both ash from a typical Australian coal and with Mgo containing low-melting salts that would serve as bonding agents (i.e., give a "flypaper" effect of the sort noted in the Bureau of Mines tests). ${ }^{31}$ Figure 8 shows the results of this set of controlled experiments. Perhaps the most significant point to note with respect to the question of immediate interest is that the amount of material deposited from the Yalbourn coal ash dropped rapidly with a reduction in temperature becoming practically zero at $500^{\circ} \mathrm{C}$. Note also that pure $\mathrm{MgO}$ with no bonding agent also gave almost no deposits at $932^{\circ} \mathrm{F}$ $\left(500^{\circ} \mathrm{C}\right)$. However, the addition of a low-melting salt in the form of sodium, potassium, or magnesium chloride or eutectic mixtures of these materials led to both heavier deposits and a shifting of the temperature for a low deposition rate to a lower value.

Experience at BCURA with a fluidized-bed coal combustor operating at temperatures in the 1450 to $1750^{\circ} \mathrm{F}$ (787 to $954^{\circ} \mathrm{C}$ ) range (which is well below the ash fusion temperature) has shown a high retention of the alkali metals in the ash. Therefore, one might at first expect that a higher turbine inlet temperature could be utilized with a fluidized-bed coal combustor than with a pulverized coal burner. However, a mixture of calctum and magneslum sulfates (compounds formed as a result of the sulfur removal 


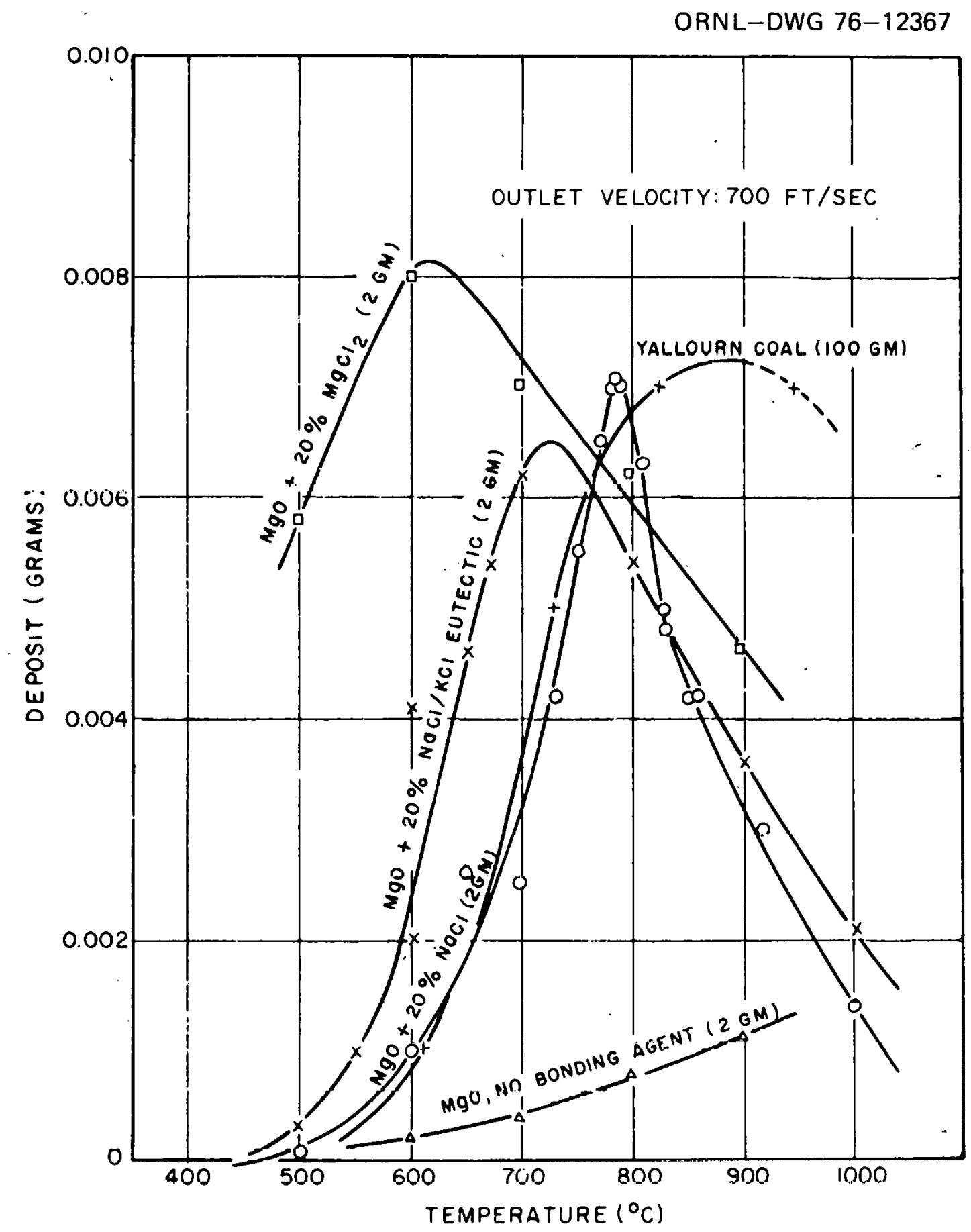

Fig. 8. Effects of temperature on the deposition rate of both coal ash and various mixtures of $\mathrm{MgO}$ and chloride salts fed into the hot-gas stream of a turbine simulation test rig in Australia. The particle size used was nominally $5 \mu \mathrm{m}$ (Ref. 33). 
operation) will form a glass that is soft and plastic at about $1300^{\circ} \mathrm{F}$ $\left(700^{\circ} \mathrm{C}\right)$ and may be expected to give the same mechanism for the buildup of deposits as the alkali metal sulfates from the pulverized coal burner. Deposits formed in the first-stage cyclone separators of the Combustion Power and BCURA units may have been caused by this calcium-magnesium sulfate glass. 57

The hardness and adherence properties of the ash deposits in coalburning gas turbines vary with the type of coal and limestone or dolomite used, the particle size, the efficiency of combustion, and the particle temperature at the instant it impinges on the metal surface. These variables greatly complicate any test program.

\section{Effects of particle size}

The buildup of ash deposits in a turbine tends to be relatively more serious than erosion as the particle size of the ingested dust is reduced. ${ }^{31,33}$ In fact, some experimenters claim to have obtained a relatively good balance between large and small particles so that the incidence of larger particles is sufficient to scrub away the deposits built up by the smaller particles. ${ }^{10,33}$ Such a favorable balance, of course, is obtained at the expense of some erosion and will be peculiar to a particular set of operating conditions, coal composition, etc.

\section{Effects of particle temperature}

The particle temperature at impact is related to the transport gas temperature and the efficiency of the coal combustor. Inefficient.combustion results in a high-carbon-content flyash which in turn results in afterburning. Experiments with an open-cycle coal-fired gas turbine resulted in deposits on the turbine blading at a gas inlet temperature of $1200^{\circ} \mathrm{F}\left(650^{\circ} \mathrm{C}\right) .{ }^{31}$ At a turbine inlet temperature of $1050^{\circ} \mathrm{F}\left(565^{\circ} \mathrm{C}\right)$, no deposits were formed. ${ }^{31}$ In a similar experiment using synthetic ash to simulate the ash from a coal-fired fluidized-bed combustor, deposits did not uccur below a temperature of $1500^{\circ} \mathrm{F}\left(816^{\circ} \mathrm{C}\right) .{ }^{58}$ Evidently, the composition of the synthetic ash differed in some way from that of the ash in the coal of the earlier test. 


\section{Corrosion}

The corrosion problem in coal-burning gas turbines is closely related to the problems posed by erosion and deposits. For example, erosion may abrade protective oxide films and thus accelerate corrosion. Deposits of alkali metal sulfates and vanadates may react with the metal in the blades to produce sulfidation and corrosion. All these mechanisms are very dependent not only on the engine design and operating conditions, but also un Lhe Lype of cual tmpluyed.

\section{Effects of temperature}

The corrosion rate of metal superheater surfaces by the products of coal combustion has been found to be very dependent on the metal operating temperature in conventional steam power plants. The flame temperature in the burners runs about $2500^{\circ} \mathrm{F}\left(1370^{\circ} \mathrm{C}\right)$ and hence the alkali metal sulfates and vanadates formed are vaporized. They subsequently tend to condense on colder metal surfaces, where they are present in liquid form in the temperature range around $1300^{\circ} \mathrm{F}\left(700^{\circ} \mathrm{C}\right) .^{76}$ If this occurs, the liquid dissolves the protective oxide film and rapid attack by the liquid occurs. Interestingly enough, the sulfates and vanadates are in,vapor form at higher temperatures, so this corrosion mechanism is not present. However, solid-state diffusion processes take place at a higher rate as the temperatures increase; hence, sulfur tends to be absorbed at the surface to form metal sulfides and migrates inwara along the grain boundaries to give a condition known as sulfidation. This effect is often dependent on local imperfections in protective oxide films and hence is widely scattered and not obvious in a cursory inspection, but it weakens the macerial.

In a fluidized-bed coal combustion system it would be expected that the alkali metal sulfates would not be vaporized as in pulverized coal burner flames. However, they will be present in the ash particles deposited in the turbine and some difficulty with sulfidation of the turbine blades may occur. Limited data available from tests at BCURA on cascades 
of blades and at Combustion Power on coupons located in the free board indicate that sulfidation is not a problem at metal temperatures of $1500^{\circ} \mathrm{F}$ $\left(816^{\circ} \mathrm{C}\right)$; however, at a metal temperature of 1700 to $1750^{\circ} \mathrm{F}\left(925-955^{\circ} \mathrm{C}\right)$, there was heavy sulfidation of the turbine blade materials in both sets of experiments. ${ }^{56,58}$ Recent work indicates that, if there is not a substantial excess of oxygen, sulfidation and corrosion under an ash deposit can be quite serious in as little as $500 \mathrm{hr}$ in the 1200 to $1500^{\circ} \mathrm{F}(650-$ $815^{\circ} \mathrm{C}$ ) range, particularly with high-nickel alloys. ${ }^{7-79}$

Effects of type of coal

Experience with open-cycle coal-fired turbines operating at 1050 to $1250^{\circ} \mathrm{F}\left(565-675^{\circ} \mathrm{C}\right)$ by the LDC, ARL, and the U.S. Bureau of Mines, utilizing a wide variety of coals from both the United States and Australia, has shown only minimal corrosion of the turbine blades after a total operating time of $7000 \mathrm{hr} \cdot{ }^{8,31,33}$ These coals were burned in pulverized coal burners at flame temperatures approaching $2500^{\circ} \mathrm{F}\left(1370^{\circ} \mathrm{C}\right)$, and the products of combustion were cooled with secondary air to the turbine operating temperatures. For a fluidized-bed coal combustor with a high retention of the alkali metals in the ash, as indicated by BCURA tests, one would expect that higher turbine inlet temperatures could be utilized for a wide variety of coals without appreciable blade corrosion. ${ }^{56}$ Recent tests indicate that, if there is more than $\sim 10 \%$ excess air, corrosion of chromium-nickel alloys should not be serious at temperatures up to the 1500 to $1600^{\circ} \mathrm{F}$ $\left(815-870^{\circ} \mathrm{C}\right)$ range. ${ }^{77-79}$

\section{$\underline{\text { Particle Separators }}$}

The open-cycle coal-fired gas turbines that have been operated have employed both conventional high-temperature cyclone separators and multicyclones to remove ash particles from the hot gases $\left(\sim 675^{\circ} \mathrm{C}\right)$ flowing out of the combustion chamber. Conventional cyclones are effective in removing most of the dust down to about $20 \mu \mathrm{m}$. Two stages are commonly employed, with the first serving as a roughing stage to remove most of the larger particles and to reduce the variation in the particulate loading induced by variations in the combustor loading. The cyclone separators are often 
followed by a third stage in the form of a multicyclone, which is a large number of small-diameter cyclone separators operating in parallel. The individual cyclones are of ten as small as $1.5 \mathrm{in.}(3.8 \mathrm{~cm})$ in diameter and are effective in removing most of the dust down to about $10 \mu \mathrm{m}$. Figure 9 shows the particle removal efficiency of a unit of this type and the pressure drop as a function of the airflow rate per unit of inlet face area of the separator bank. ${ }^{67}$ These data were for dust in which $25 \%$ by weight of the particles had equivalent diameters of less than $10 \mu \mathrm{m}$.

Removal of particles below about $5 \mu \mathrm{m}$ is best accomplished with some form of fabric filter if the gas temperature is below $500^{\circ} \mathrm{F}\left(260^{\circ} \mathrm{C}\right)$.

\section{INERTIAL SEPARATOR PERFORMANCE INDICES}

MULTIPLE MINIATURE CYCLONES -I.5 IN.O.D. X 6.0 IN. LONG (TWO IN SERIES) FLOW/SIZE INDEX, CFM/CU FT SEPARATOR VOLUME (1OO'S)

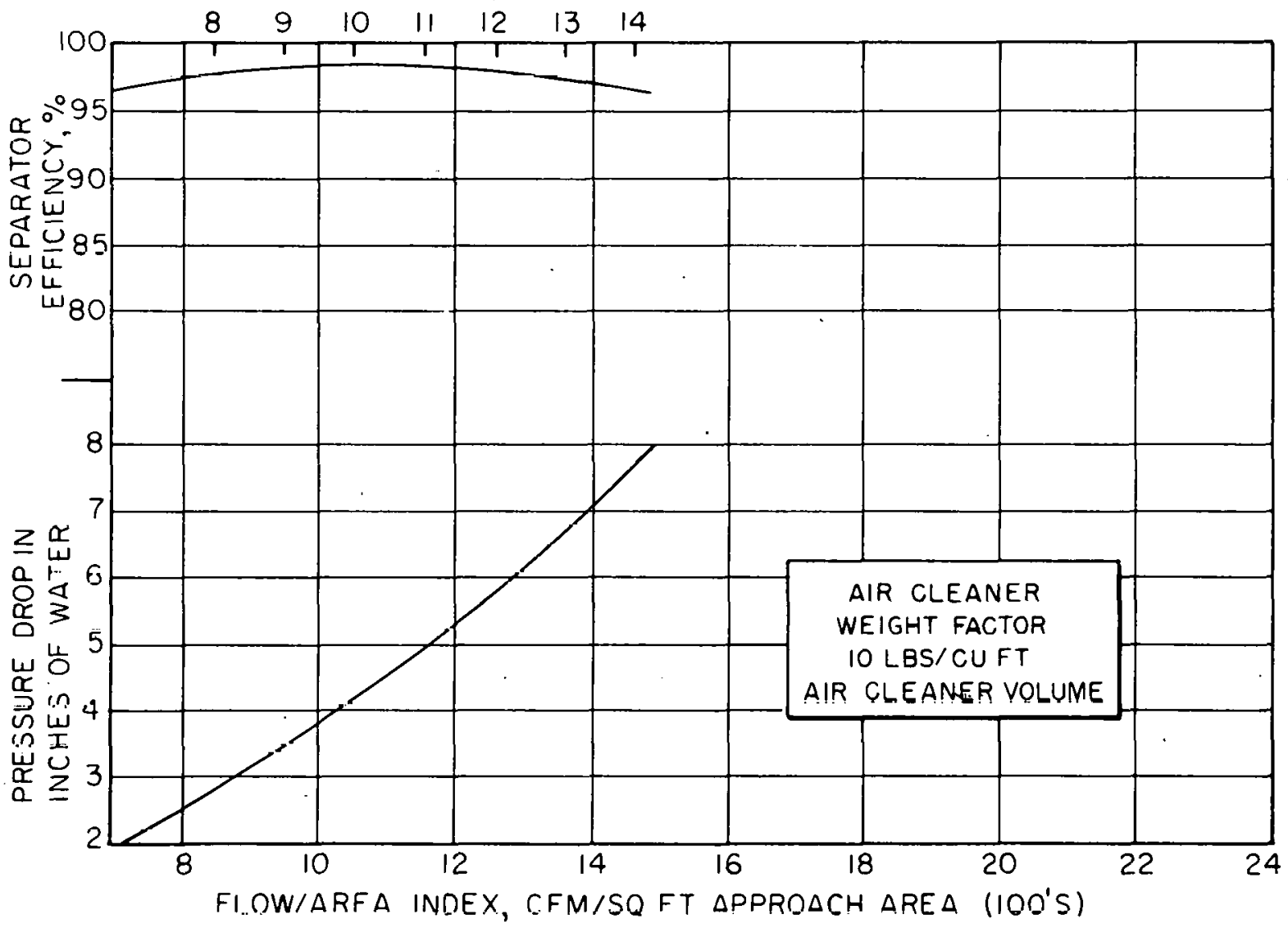

Fig. 9. Separator performance characteristics for 1.5- by 6-in. tubes in series. Performance is based on a scavenging airflow requirement of $15 \%$ of the airflow rate (Ref. 67). 
Electrostatic precipitators can be used at temperatures to about $1000^{\circ} \mathrm{F}$ $\left(537^{\circ} \mathrm{C}\right)$. At higher temperatures the electrical conductivity of the coal ash becomes sufficient that deposits formed on the electrical insulators produce high tension shorts that prevent the buildup of an adequate voltage to give effective electrostatic precipitation. Further, because of the relatively low velocities involved, the size and cost of the pressure vessel required to house the large volume of precipitator plates present serious problems if such a unit is installed between the combustor and a gas turbine where the pressure will run $\sim 10 \mathrm{~atm}$.

\section{CURRENT STATUS OF DEVELOPMENT}

The current status of the development of the open-cycle coal-fired gas turbine as determined from a review of available pertinent literature indicates that, with careful design of the turbine and ash removal system, acceptable operation can be attained for turbine inlet temperatures up to about $1200^{\circ} \mathrm{F}\left(650^{\circ} \mathrm{C}\right)$ and particulate loadings of approximately 100 ppm. However, the present interest in the use of a pressurized fluidizedbed coal combustor for a combined-cycle power plant requires that the turbine inlet temperature be increased to the 1500 to $1600^{\circ} \mathrm{F}\left(815-870^{\circ} \mathrm{C}\right)$ range, ${ }^{80-82}$ and this apparently requires that the particulate content of the hot gas be less than $21 \mathrm{ppm}$. Thus present development thrusts arc directed toward more effective hot-gas cleanup methods. Among the methods being evaluated are high-efficiency cyclones; granular bed filters; metallic and/or ceramic cloth filters; and high-pressure, high-temperature electrostatic precipitators. Dilution of the combustion gas stream with air heated in the fluidized bed is another method of reducing the particulate loading in the gas turbine inlet stream, ${ }^{82}$ and the Curtiss-Wright Corporation is in the midst of an experimental program to investigate this possibility. As can be deduced from the flowsheet in Fig. 10, this entails the use of about one-third of the air discharged from the compressor as combustion air for the fluidized bed, while the other two-thirds passes through tubes in the fluidized bed to remove about two-thirds of the heat of combustion. The combustion gases are cleaned up and recombined with the clean air heated by the bed and fed to the turbine. This approach 


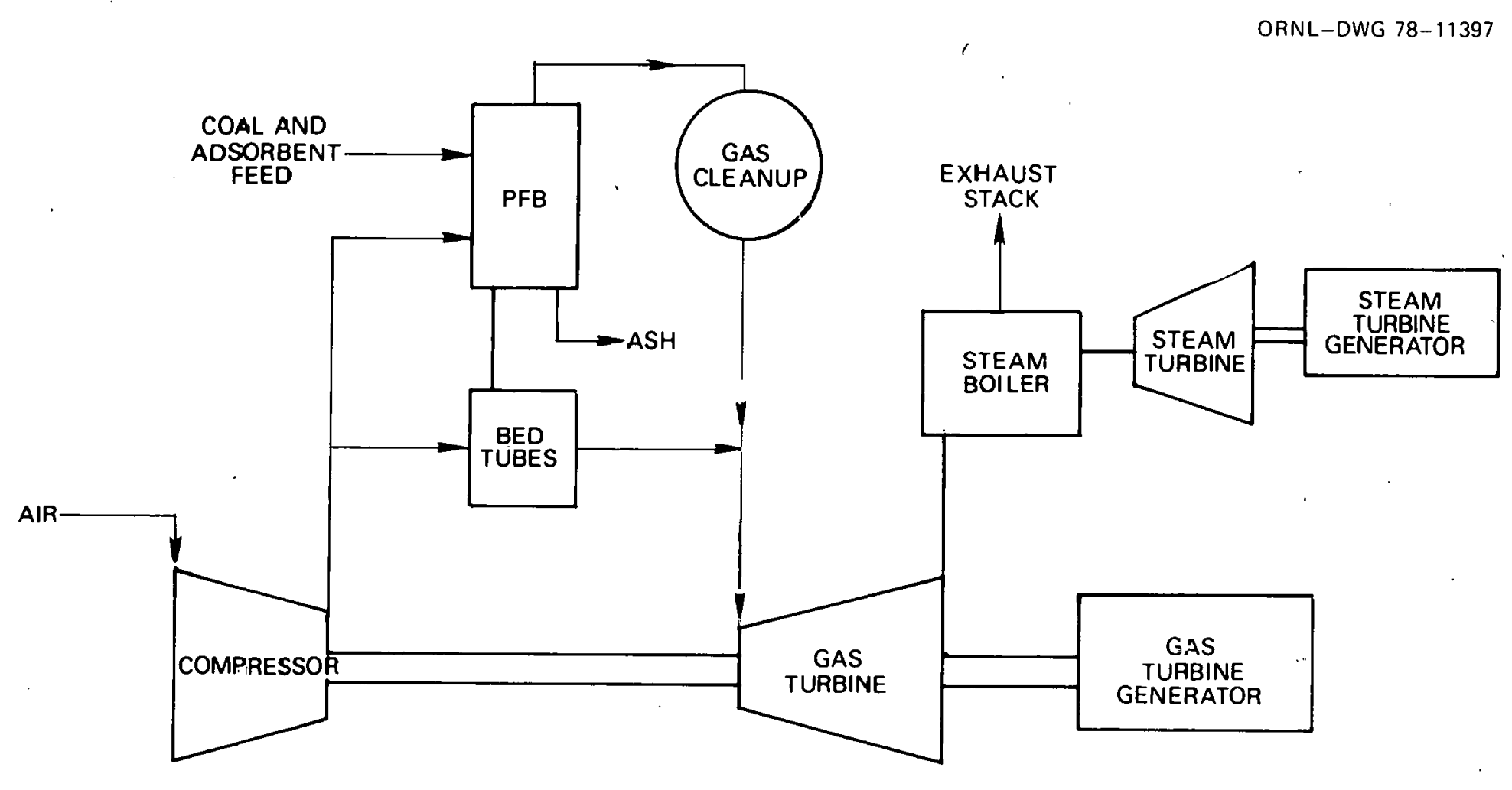

Fig. 10. Jimplified F-owsheet for the Curtiss-Wright pressurized fluidized bed-gas turbine-steam turbine combined sycle power system. ${ }^{82}$ 
greatly reduces both the size and the required efficiency of the particle separation equipment.

The crux of the problem is to obtain a particulate removal system that will operate at a temperature of approximately $1600^{\circ} \mathrm{F}\left(870^{\circ} \mathrm{C}\right)$ for long periods of time without either clogging to give an excessive pressure drop or losing its effectiveness in removing particulate matter. The status of the principal experimental efforts is outlined below.

\section{Exxon Research and Engineering Company}

The Exxon Miniplant flue gas exits from a $30-\mathrm{cm}-\mathrm{diam}$ fluidized-bed combustor and discharges through two stages of cyclone separators. The solids from the first-stage cyclone are returned to the combustor, and those from the second-stage cyclone are discarded by means of a lock hopper system. The discharge gases from the second-stage cyclone are further cleaned by a granular bed filter before entering the test section for the simulated turbine. The hot gases enter the filter at approximately 9 atm and 1200 to $1550^{\circ} \mathrm{F}\left(650-843^{\circ} \mathrm{C}\right)$.

A series of tests has been run with granular bed filters. ${ }^{83}, 84$ The first set of these was run with hot-gas downflow through a 50-mesh inlet screen and a bed of 250- to 600-mesh particles of crushed quartz. The inlet screens clogged quickly, so that it was necessary to clear them at intervals of 5 to $10 \mathrm{~min}$ by blowing back first one and then another of several units operating in parallel. However, the backflow operation was only partially effective in clearing the units and reducing the pressure drop to the design range; the pressure drop became excessive within 24 hr of running. The filters were then modified by removing the inlet screens; this helped but led to excessive losses of the fine silica particles in the filter bed. This problem was corrected by changing to coarser particles of crushed alumina $(840-1400 \mu \mathrm{m})$. Tests with these at the time of writing indicate that when starting with a clean bed the particulate content in the exit gas stream can be held to the EPA specification for stack emissions of 0.05 grain $/ \mathrm{ft}^{3}$ (gas volume at standard conditions). However, the fine dust tends to intermix with the granular bed when it is fluidized 
during the blowback operation, and after a few hours of running the particulate content of the gas leaving the bed rises to the point where it exceeds the target limit of 0.05 grain $/ \mathrm{ft}^{3}$. Efforts are under way at the time of writing to improve the arrangements for clearing out the fines in the blowback operation.

It should be noted that the EPA limit of 0.05 grain $/ \mathrm{ft}^{3}$ is for the stack gas emissions to the atmosphere. This value corresponds to approximately $100 \mathrm{ppm}$ and is about 100 times as high as can be tolerated in a gas turbine designed to operate with an inlet temperature of about $1550^{\circ} \mathrm{F}$ $\left(843^{\circ} \mathrm{C}\right)$.

\section{Combustion Power Company}

Combustion Power Company is using a moving granular-bed filtration system for removal of particulate material from the hot-gas stream supplied to a gas turbine. ${ }^{85}$ The bed is in the form of a cylindrical annulus about 11.8 in. $(30 \mathrm{~cm})$ thick contained between two sets of louvered plates with the louvers sloped inward toward the bed so that the granular material is contained (see Fig. 11). The concept entails gradual movement

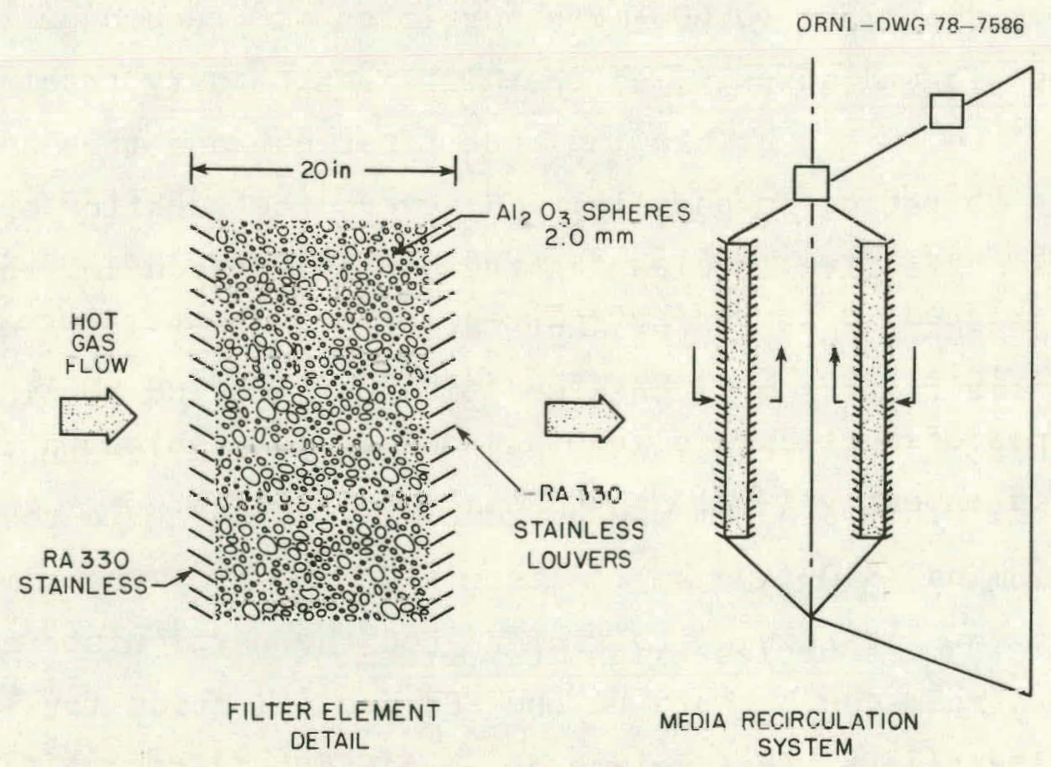

Fig. 11. Description of the Combustion Power Co. design for an granular-bed filter. 
of the granular material downward through the bed so that the filter cake on the inlet face is broken up and fine particles that get into the bed can be removed in the course of recycling the granular material from the bottom to the top of the bed. A test with a full-scale hot-flow unit was terminated in the initial shakedown by a creep buckling type of failure. This led to the decision to run a reduced-scale cold-flow test as the next step. A cold-flow model has been built and tested to determine the effects of bed thickness, filter media size, and flow rates on filtration performance. Data from these experiments show that particulate loadings of as low as $20 \mathrm{ppm}$ can be obtained in the exit gas stream. ${ }^{86}$ These data are being used to design a system for operation with a fluidized-bed coal combustor.

\section{NASA-Lewis Research Center}

The NASA-Lewis fluidized bed is a combination of a cylindrical and a conical bed. ${ }^{87}$ The fuel is burned in the lower cylindrical bed, while the upper conical bed serves as a fixed bed filter for the flue gases supplied to a turbine test section. The system became operable in 1977 , and a test program involving a turbine section, high-temperature cyclones, and a high-temperature ceramic filter is scheduled to begin in early 1978.

\section{Westinghouse Research and Development Center}

A high-temperature, high-pressure test facility is being constructed by the Westinghouse R\&D Center to test particulate control equipment. The facility is designed to investigate the effects of temperature, pressure, flow rate, particle type, loading, and size distribution on the performance of various types of particulate removal devices. ${ }^{88}$ Shakedown runs are expected to begin in early 1978.

\section{Curtiss-Wright Corporation}

The Curtiss-Wright program to develop a pressurized fluidized-bed combustion system coupled to a gas turbine has entailed, as a first major 
step, the design and construction of a facility called the Small Gas Turbine-Pressurized Fluidized Bed (SGT/PFB) rig. ${ }^{82}$ This unit employs a $3-\mathrm{ft}$ (0.8-m-diam) fluidized-bed furnace designed to operate at 6.5 atm. A portion of the combustion products passes through a series of cyclone separators and a granular-bed filter en route to a small gas turbine. The effectiveness of various designs for the particle removal equipment will be determined as a function of the principal variables. Concurrently, the effects of the particulate content of the combustion gas entering the gas turbine on curbine bucket erosion and deposits will be investigated. The test rig was undergoing shakedown tests as of January 1978. Test results should begin to be available by mid-1978.

\section{Deposits of Particulates Entering with the Inlet Air}

Commercial gas turbines have been troubled by deposits stemming from dust in the inlet air stream. As a consequence, the engine manufacturers recommend that air filters be incorporated in the installation to keep the dust content to less than $\sim 2 \mathrm{ppm},{ }^{89}$ and this is commonly found necessary in many urban environments. However, recent experience indicates that even tighter restrictions are required as the turbine inlet temperature is increased. One of the first strong indications of this was encountered in a 1974 gas turbine acceptance test at the Philadelphia Navy Yard. Substantial deposits were noted after only a few hundred hours of operation under cycling conditions in which the average turbine inlet temperature was in the $2100^{\circ} \mathrm{F}\left(1150^{\circ} \mathrm{C}\right)$ range about half the time. ${ }^{90}$ The cooling air discharge ports in the first stage stator blades were affected and some blades were damaged by overheating (Fig. 12). Investigation disclosed that the bulk of the deposit consisted of submicron-size $\mathrm{Fe}_{2} \mathrm{O}_{3}$ particles that entered the engine with the inlet air that had a particulate content of only $0.06 \mathrm{ppm}$. Further investigation disclosed that Philadelphia air was not dirtier in this respect than the air in most localities and that the deposits did not form when the nominal turbine inlet temperature was limited to $\sim 1800^{\circ} \mathrm{F}\left(982^{\circ} \mathrm{C}\right)$. Note that the melting point of the $\mathrm{Fe}_{2} \mathrm{O}_{3}$ is $2860^{\circ} \mathrm{F}\left(1570^{\circ} \mathrm{C}\right)$ which implies a sintering temperature of $\sim 2030^{\circ} \mathrm{F}\left(1110^{\circ} \mathrm{C}\right)$. 


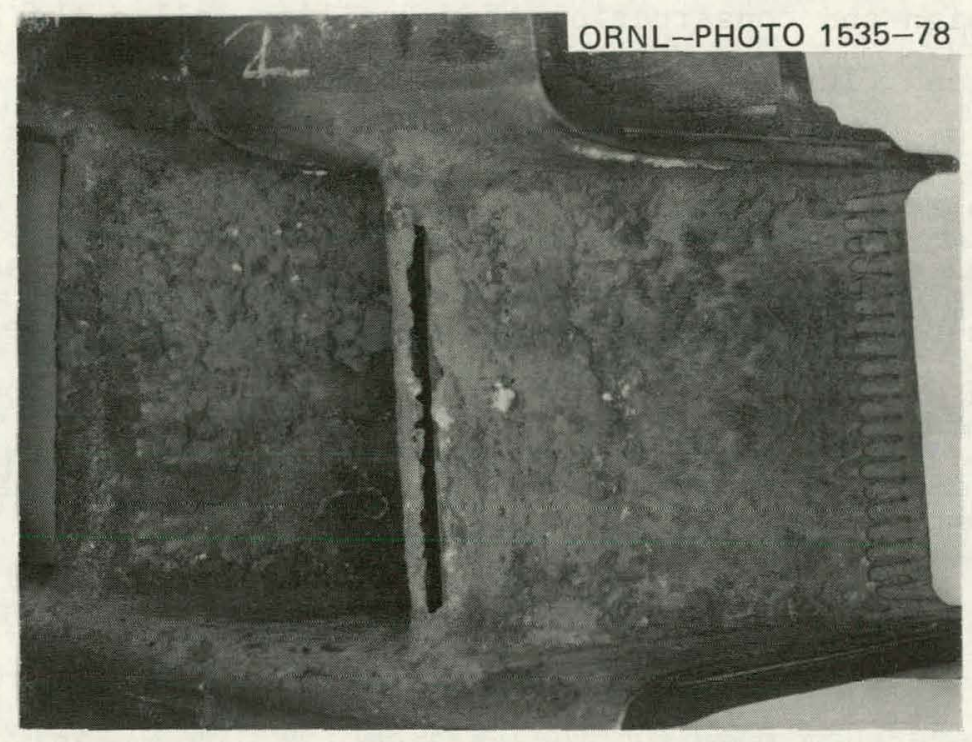

Fig. 12. Photograph of two first-stage stator vanes from an LM2500 engine after cycled operation at the Philadelphia Navy Yard. Note that deposits on the blades have partially blocked the cooling air discharge ports near the leading edge of the vane at the left and the blockage of ports near the leading edge of the blade at the right led to severe overheating and burning of a slot through what was the cooling air discharge port region (courtesy of the Philadelphia Navy Yard).

This appears to be the reason that this type of deposit did not prove a problem until operations at a turbine inlet temperature of $2100^{\circ} \mathrm{F}\left(1150^{\circ} \mathrm{C}\right)$ were initiated. Note, too, that coal ash commonly contains $25 \% \mathrm{Fe}_{2} \mathrm{O}_{3}$.

Recent work by NASA, ${ }^{91}$ Westinghouse, ${ }^{92-94}$ and UTC (United Technologies Corp.) seems to be consistent with the Navy experience. One of the interesting analyses of the problem was evolved by G. Vermes at Westinghouse to explain the markedly heavier deposits found on both the pressure and suction surfaces in engines with cooled blades. He has shown that the temperature differential between hot particles in the gas stream and the cooler metal blade surfaces induces a force that drives the particles toward the blade surface and causes them to adhere, a phenomenon he calls "thermophoresis."93 His analytically derived relations correlate a substantial amount of experimental data surprisingly well and support his analytical relations indicating that the greater the temperature difference and the smaller the particle, the greater the deposition rate. 
Another analytical study carried out at Westinghouse by Chamber1in ${ }^{94}$ indicates that Brownian movement effects in the boundary layer also tend to cause the deposition of submicron-size particles on both the pressure and suction surfaces. Burner rig tests both at $\mathrm{NASA}^{91}$ and at UTC have demonstrated that these deposits form at high temperatures and tend to clog the small cooling air discharge ports in the blades. Note that the UTC tests were carried out with $\mathrm{Al}_{2} \mathrm{O}_{3}$ dust with a melting point far above the gas temperature, yet the deposits formed were hard and adherent. Apparently, trace amounts of lower-melting-point materials act as binders to fuse high-melting-point materials such as $\mathrm{Fe}_{2} \mathrm{O}_{3}$ and $\mathrm{Al}_{2} \mathrm{O}_{3}$ into hard ceramic deposits. These are not only adherent, but there seems to be no simple method to remove them from suction surfaces; a water wash with crushed nut shells is effective only for removing deposits on pressure surfaces.

This test experience, together with the related studies, has serious implications for both water-cooled blades and transpiration air-cooled blades intended for turbine inlet temperatures in the 2500 to $3000^{\circ} \mathrm{F}(1370$ to $1650^{\circ} \mathrm{C}$ ) range. From this standpoint, perhaps the most significant test projected for the near future is a 1000-hr test planned by Curtiss-Wright Corp. In this test one of their engines will be run with a turbine inlet temperature of $\sim 3000^{\circ} \mathrm{F}\left(1650^{\circ} \mathrm{C}\right)$ using transpiration-cooled blades designed to operate with a metal temperature of $1350^{\circ} \mathrm{F}\left(732^{\circ} \mathrm{C}\right)$. Flyash from a Commonwealth Edison coal-fired steam plant will be added to the combustion air with operation on clean distillate fuel. ${ }^{95}$ Three levels of particulate flow rate will be investigated: $\sim 2 \mathrm{ppm}$ with $80 \%$ smaller than $1 \mu \mathrm{m}$, $\sim 10 \mathrm{ppm}$ with $80 \%$ under $2 \mu \mathrm{m}$, and $\sim 20 \mathrm{ppm}$ with $80 \%$ smaller than $2.5 \mu \mathrm{m}$. The alka1i metal content of the distillate fuel oil will be held to $0.65,3.4$, and $6.5 \mathrm{ppm}$, respectively.

Summary

The various particulate removal systems presently being evaluated by DOE contractors are designed to offer a workable method of removing particles below $5 \mu \mathrm{m}$ at temperatures in the 1600 to $1900^{\circ} \mathrm{F}\left(870-1040^{\circ} \mathrm{C}\right)$ range 
and thus clean up the fluidized-bed coal combustor flue gas stream sufficiently to permit good gas turbine operation. These values represent experimental objectives and have not as yet been demonstrated. A thorough examination of the many experiments that have been and are being conducted indicates that it is doubtful that any of the concepts being investigated will give the low particulate contents required for the economical operation of 1500 to $1600^{\circ} \mathrm{F}$ ( 816 to $870^{\circ} \mathrm{C}$ ) long-lived gas turbines.

\section{REFERENCES}

1. A. P. Fraas, Comparison of Advanced Energy Conversion Systems on the Basis, of Research and Devezopment Experience, ORNL-TM-6259 (to be published).

2. A. P. Fraas, Summary of the Development of Steam Power Plants for Central Stations, ORNL-TM-6250 (to be published):

3. A. P. Fraas and A. S. Thompson, Research and Development Experience and Current Status of Development of Open-Cycle Gas Turbines, ORNLTM-6251 (to be published).

4. M. E. Lackey and A. S. Thompson, Summary of the Development of OpenCycle Gas Turbine-Steam Combined Cycles, ORNL-TM-6252 (to be published).

5. Adolph Meyer, "The Velox Steam Generator - Its Possibilities as Applied to Land and Sea," Mech. Eng. 57, 469 (1935).

6. A. E. Pew, Jr., "Gas Turbine Operation in Sun Oil Refineries," Fower Plant Engineering, pp. 77-79, August 1945.

7. Curt Keller, "The Escher Wyss-AK-Closed-Cycle Turbine, Its Actual Development and Future Prospects," Trans. ASME 68, 791 (November 1946).

8. Progress Report No. 1 to The Locomotive Development Committee, May 1 to August 1, 1945, Bituminous Coal Research, Inc., Dunkirk, N.Y., Aug. 25, 1945.

9. "Coal-Fired Gas Turbine," Mech. Eng. 81, 79 (May 1959).

10. M. A. Fisher and E. F. Davis, "Studies on Fly-Ash Erosion," Mech. Eng. 71, 481 (June 1949).

11. J. I. Yellott, P. R. Broadly, and W. M. Meyer, Semi-Annual Report to the Locomotive Development Committee of Bituminous Coal Research, Inc., May 1, 1949, to Nov. 30, 1949, The Locomotive Development Committee of Bituminous Coal Research, Inc. (Nov. 30, 1949). 
12. J. I. Yellott, "An Experimental Coal-Burning Gas Turbine," Midwest Power Conference, Locomutive Development Committee, Bituminous Coal Research, Inc., Chicago, I11., April 1950.

13. J. I. Yellott, P. R. Broadley, and D. Buckley, "Progress Report on the Coal-Burning Gas Turbine," Midwest Power Conference, Locomotive Development Committee, Bituminous Coal Research, Inc., Chicago, I11., April 1951.

14. J. I. Yellott, P. R. Broadley, and D. Buckley, First $1000 \mathrm{hr}$ of CoalBurning Gas-Turbine Tests, Power, June 1951.

15. J. I. Yellott and P. R. Broadley, Annual Report to the Incomotiv日 Levelopmert Committee of Bituminous Coal Research, Inc., May 1, 1950, to Apriz 30, 1951, The Locomotive Development Committee of Bituminous Coal Research, Tnr: (June 1951).

16. P. R. Broadley and W. M. Meyer, "Direct-Fired Coa1-Burning Gas-Turbine Operations," Conference on Coal-Burning Gas Turbines, McGill University, Montreal, Quebec, November 1956.

17. J. I. Yellott and P. R. Broadley, "Progress Report on Preliminary Tests of a 4250 Horsepower Coal-Burning Locomotive-Type Gas Turbine Fower Plant," American Power Conference, Locomotive Development Committee, Bituminous Coal Research, Inc., Chicago, Ill., March 1952.

18. J. I. Yellott and P. R. Broadley, Progress Report, Jurle 1 to oet. 31, 1951, The Locomotive Development Committee, Bituminous Coal Researsh, Iuc. (Oc Tóber 1951).

19. J. I. Yellott and P: R. Broadley, "1952 A Year uf Cual-Burning Turbine Progress," Rail.woy Ago, $\Lambda$ pr. 20, 1953.

20. J. I. Yellott and P. R. Broadley, Photographic Report Number 51-1, Mechanical Advisory Group, Locomotive Development Committee, Bituminous Coal Research, Inc. (December 1951).

21. J. I. Yellott and P. R. Broadley, "Prngress Continuec on Coal-Durnilig Gas Turbine Plant," Power Engineering, June 1953.

22. J. I. Yellott, P. R. Broadley, and W. M. Meyer, "Acceptance and Operational Teste of a $4250 \mathrm{HF}$ Codl-Burning Gas lurbine," Power I-Preliminary Dill-Fired Operation, Caa Turbine Power Division Fall Meeting, Milwaukee, Wisc., ASME Paper 54-F-39, September 1954.

23. J. I. Yellott, P. R. Broadley, and W. M. Meyer, "Acceptance and Operational Tests of a $4250 \mathrm{HP}$ Coa1-Burning Gas Turbine," Part II-Coa1Fired Operation, Gаз Turbine Füer Dlvision, Fall Meeting, Milwaukee, Wisc., ASME Paper No. 54-F-40, September 1954. 
24. J. I. Yellott, Report on 750 Hour Test of 4250 Ilorsepower Coal-Fired Gas Turbine Power Plant, Locomotive Development Committee, Bituminous Coal Research, Inc. (September 1952).

25. J. I. Yellott et al., 300 Hour Test on 4250 HP Coal-Burning Gas Turbine, Photographic Report Number 54-1, Locomotive Development Committee, Bituminous Coal Research, Inc. (September 1954).

26. J. I. Yellott, P. R. Broadley, and W. M. Meyer, Technical Supplement, The Progress of the LDC-AZco Coal-Burning Gas Turbine Project During the Period from October 1, 1954, to September 1, 1955, 1955 Annual Report to the Locomotive Development Committee of Bituminous Coal Research, Inc., Bituminous Coal Research, Inc. (September 1955).

27. J. I. Yellott, P. R. Broadley, and W. M. Meyer, Summary of Operation of the LDC-Alco Coal-Burning Gas Turbine Project, October 1, 1954, to September 1, 1955, Summary of 1955 Operation, Bituminous Coal Research, Inc. (September 1955).

28. P. R. Broadley and W. M. Meyer, 1957 Annual Report of the Locomotive Development Committee, Locomotive Development Committee, Bituminous Coal Research, Inc. (1957).

29. R. W. Foster-Pegg, "Combined Steam Gas-Turbine Cycle to Use Coal," Mech. Eng., February 1959.

30. "Coal-Fired Gas Turbine Is Road Tested in Freight Service," Railway Locomotives and Cars, January 1963.

31. J. Smith et a1., Bureau of Mines Coal-Fired Gas Turbine Research Project: Tests of New Turbine Blade Design, BM-RI-6920, Bureau of Mines, United States Department of Interior (1967).

32. R. M. Junge and G. W. Scheper, Jr., Locomotive Development Committee Coal-Fired Turbine Blade Erosion Study, Technical Information Series No. DF-59-GTD-32, General Electric Co. (Dec. 18, 1959).

33. The Coal-Burning Gas Turbine Projeat - Report of the Interdepartmental Steering Committee, Department of Minerals and Energy-Department of Supply, Australian Government Publishing Service, Canberra (1973).

34. F. D. Buckley and P. D. Rotzler, Operation of an Open-Cycle Gas Turbine Plant with Australian Lignite Dust, Locomotive Development Comm1ttee, Dunk1rk, N.Y. (December 1951).

35. M. L. Atkin and G. A. Duke, The Operation of a Ruston and Homsby Gas Turbine on Queensland Coal, ARL/ME Report 131, Melbourne, Australla (Apri1 1971).

36. M. L. Atkin and G. A. Duke, The Operation of a Modified Ruston and Hornsby Gas Turbine on N.S.W. Bituminous Coal, ARL/ME Report 133, Melbourne, Alstralia (September 1971). 
37. L. M. Stettenbenz, "Power-Recovery' Gas Expander Gains in FCC Cycle," The Oil and Gas soumal, p. 60, Dec. 18, 1972.

38. J. G. Wilson and J. C. Dygert, "Separator and Turbo-Expander for Erosive Environments," Proceeding of the Seventh World Petroleum Congress, Mexico City, April 1967, p. 95.

39. J. P. Balfoort, "Improved Hot-Gas Expanders for Cat Cracker Flue Gas," Hydrocarbon Processing, p. 142, March 1976.

40. J. C. Dygert, "Power-Recovery Gas Turbines for Fluid-Bed Process," The Oil and Gas Joumal, p. 94, Apr. 20, 1959.

11. J. G. Wilson, "Eutrgy Recovery Pays Utt at Three She11 Refineries," The Oit and frof .Tommal, p. 77, $\Lambda \mathrm{pr}, 18,1066$.

42. H. L. Franzel and D. W. Miller, "Cleaner Stack Gases Are a Bonus," The Oil and Gas Joumat., p. 95, Mar. 24, 1969.

43. L. W. Steltenbenz, "Minimizing Erosion and Afterburn in the PowerRecovery Gas Iurbines," The Oit and Gas Joumal, p. 65, Oct. 19, 1970.

44. S. S. Brown, "Power Recovery Pays off at Shell 0il," The Oil and Gas Journal, p. 128, May 21, 1973.

45. A. L. Jaumotte and J. Hustin, "Experience Gained from a Ten-Year Operation of a Gas Turbine Working with Blast Furnace Gas," ASME Paper No. 66-GT-97, 1966.

46. A. Strub, "Field Experience with Industrial Gas Turbine Installation," Sulzer Technical Review, 48/1966, No. 3, p. 129, BST Brnwn RnveriSulzer Turbomachinery Ltd.

47. H. Pfenninger, "Operating Results with Gas Turbines of Large Output," Journal of Engineering for Power, p. 29, January 1964.

48. E. Aguet and J. Von Salis, "Three Years' Operating Experience with $7500 \mathrm{~kW}$ Gas Turbine Plants in Belgian Steelworks," ASME Paper No. 60-GTP-3, March 1960.

49. P. C. Felix, personal communication to A. P. Fraas, Apr. 3, 1975, summarizing Brown Boveri blast furnace gas turbine operating experience in Europe.

50. A. Frieder, personal communication to A. P. Fraas, July 12, 1976, summarizing Sulzer blast furnace gas turbine operating experience in Europe.

51. K. Bund, K. A. Henney, and K. H. Krieb, "Combined Gas/Steam Turbine Generating Plant in the Kellermann Power Station at Lunen," STEAG, Anlagentechnik, 1970. 
52. Sulzer display of eroded blades at the ASME Annual International Gas Turbine Conference and Products Show, Houston, Tex., Mar. 2-6, 1975.

53. A. D. Foster, H. Doerning, and J. W. Hickey, Fuel Flexibility in Heavy-Duty Gas Turbines, GER-2222J, General Electric Co. (1974).

54. S. V. Lee and W. E. Young, "Gas Turbine Hot-Stage Parts in Agressive Atmospheres," Journal of Engineering for Power, p. 540, October 1976.

55. H. R. Hoy and J. E. Stantan, "Fluidized Combustion under Pressure," paper presented at the Joint Meeting of the Chemical Institute of Canada and the Division of Fuel Chemistry of the AIChE in Toronto, Canada, May 24, 1970.

56. Pressurized Fluidized Bed Combustion Research and Development Report No. 85, Interim No. 1, prepared for Office of Coal Research, Department of the Interior, by National Research Development Corporation, London, England.

57. D. A. Furlong and G. L. Wade, "Use of Low Grade Solid Fuels in Gas Turbines," ASME Paper No. 74-WA/ENER-5, presented at the ASME Winter Annual Meeting, Nov. 18, 1974.

58. Energy Conversion from Coal Utilizing CPU-400 Technology - Monthly Report for August 1976, FE-1536-M37, Combustion Power Company, Inc. (September 1976).

59. W. G. Stevens and A. R. Stetson, Corrosion and Erosion Evaluation of Turbine Materials in an Environment Simulating the CPU-400 Combustor Operating on Coal, DOE Report FE/1536-3 (April 1977).

60. S. J. Van Grouw, "Corrosion Studies and High Temperature Filtration," Proceedings of the Fluidized Bed Combustion Technology Exchange Workshop, Apr. 13-15, 1977, NTIS CONF-770447-P-2, Vol. II.

61. A. P. Fraas, "Survey of Turbine Bucket Erosion, Deposits, and CorroEion," $\Lambda$ SME Paper No. 75-CT-123, March 1975.

62. A. P. Fraas, G. Samuels, and M. E. Lackey, "A New Approach to a Fluidized Bed Steam Boiler," ASME Paper No. 76-WA/PWR-8, December 1976.

63. C. E. Smeltzer and W. A. Compton, Mechanisms of Sand and Dust Erosion in Gas Turbine Engines, Solar Division, IHC, U.S. AvLabs Contract DAAJ02 68 c. 0056, AD 680200 (Scptembcr 1968).

61. C. D. Wood and P. W. Esponschade, "Mochanisme of Dust Erosion," SAE Trans. 73, 515 (1965).

65. G. Grant and W. Tabakoff, "Erosion Prediction in Turbomachinery Resulting from Environmental Solid Particles," J. Aircraft 12(5), 471 (May 1975). 
66. W. Tabakoff, W. Hosny, and A. Hamed, "Effect of Solid Particles on Turbine Performance," Journal of Engineering for Power, p. 47, January 1976.

67. M. G. Mund and Hanspeter Guhne, "Gas Turbine-Dust-Air Cleaners: Experience and Trends," ASME Paper No. 70-GT-104, January 1970.

68. J. H. Horton, "Environmental Factors in Engine Design for Military Applications," ASME Paper No. 65-GTP-1, February 1965.

69. E. L. Bulkley, "New Studies Shed Light on Erosion Problems," Petro/ Chem Eng., p. 218, March 1962.

70. "Dust Erosion Parameters for Gas Turbine," Hetro/Chem Eng., p. 198, December 1962.

71. G. R. Zellars et al., "Corrosion/Erosion of Turbine Blade Materials in the High Velnsity Fffluent of a Pressurized Fluidized Conal Combustor," Proceedings of the Fifth Intermational Conference on Fluidized Bed Combustion, Washington, D.C., Dec. 12-14, 1977.

72. A. P. Fraas, H. C. Young, and A. G. Grindell, Survey of Information on Turbine Bucket Erosion, ORNL-TM-2088 (Ju1y 1968).

73. B. Wood, "Wetness in Steam Cycles," Proc. Inst. Mech. Eng. 174(14), 491-511 (1960).

74. J. H. Brunton, Liquid Impact and Material Removal Phenomena, Sumary of Turbine Erosion Meeting, Jet Propulsion Laboratory Technical Memorandum No. 33-354, pp. 173-91 (June 1967).

13. D. H. E'vane and W. D. Pouchet, t'low S'tudies in a Wot stoam l'urbino, NASA CR-134683, prepared for NASA by Westinghouse Electric Corporation (Aug. 13, 1974).

76. S. A. Goldberg et al., "A Laboratory Study of High-Temperature Corrosion on Fireside Surfaces of Coal-Fired Steam Generators," Trans. ASME 20, 193 (April 1968).

77. J. Stringer and S. Ehrlich, "High Temperature Corrosion in Fluidized Bed Combustors," ASME Paper No. 76-WA/CD-4, December 1976.

78. J. Stringer, "High Temperature Corrosion of Metals and Alloys in Fluidized Bed Combustion Systems," Proceedings of the Fifth International Conference on Fluidized Bed Combustion, Washington, D.C., Dec. 12-14, 1977.

79. A. F. Fraas and R. S. Ilolcomb, "Atmospheric Fluidized Ded Technology Test Unit for Industrial Cogeneration Plants," Proceedings of the Fifth International Conference on Fluidized Bed Combustion, Washington, D.C., Dec. 12-14, 1977. 
80. D. H. Brown et al., Energy Conversion Altermatives Study (ECAS), General Electric Phase II Final Report, Vol.. II, Advanced Energy Conversion Systems - Conceptual Designs, Part 2, Closed Cycles, NASA-CR-134949, SRD-76-064-2 (December 1976).

81. D. T. Beecher et al., Energy Conversion Altematives Study (ECAS), Westinghouse Phase II Final Report, Summary and Advanced Steam Plant with Pressurized Fluidized Bed Boilers, NASA-CR-134942, Vol. III (November 1976).

82. S. Moskowitz, "The Curtiss-Wright Pressurized Fluidized Bed Pilot Electric Plant," Proceedings of the Fifth International Conference on Fluidized Bed Combustion, Washington, D.C., Dec. 12-14, 1977.

83. M. S. Nutkis et al, "Evaluation of a Granular Bed Filter for Particulate Control in Fluidized Bed Combustion," Proceedings of the Fifth International Conference on Fluidized Bed Combustion, Washington, D.C., Dec. 12-14, 1977.

84. M. S. Nutkis and M. D. Loughnane, "A Program for Hot Corrosion/Erosion Materials Testing for Application to Fluidized Bed Coal Combustion," Proceedings of the Fluidized Bed Combustion Technology Exchange Workshop, April 13-15, 1977, Vo1. II, CONF-770447-P-2, p. 217.

85. S. J. Van Grouw, "Corrosion Studies and High Temperature Filtration," Proceedings of Fluidized Bed Combustion Technology Exchange Workshop, Vo1. II, CONF-770447-P-2, P. 235.

86. J. L. Guillory, "Filtration Performance of a Moving Bed Granular Filter: Experimental Cold Flow Data," Proceedings of the Fifth International Conference on Fluidized Bed Combustion, Washington, D.C., Dec. .12-14, 1977.

87. R. J. Priem, "NASA's Pressurized Fluidized Bed," Proceedings of Fluidized Bed Combustion Technology Exchange Workshop, Vol. II, CONF-770447-P-2, p. 149.

- 88. D. L. Keairns et a1., "Experimental and Engineering Investigations for the Development of Fluidized Bed Combustion Processes," Proceedings of Fluidized Bed Combustion Technology Exchange Workshop, Vol. II, CONF-770447-P-2, p. 97.

89. "Gas Turbine Inlet Air Treatment," General Electric Gas Turbine Reference Library, GER-2490.

90. E. P. Weinert, Naval Ship Engineering Center, personal communication to A. P. Fraas in March 1975 and February 1978.

91. D. L. Deadmore and C. E. Lowell, Plugging of Cooling Holes in FilmCooled Turbine Vanes, NASA TMX-73661 (April 1977). 
92. "High Temperature Turbine Technology Program, Phase I - Program and System Definition, Topical Report - Fuels Cleanup and Turbine Tolerance," prepared by Westinghouse Electric Corp. for ERDA, FE-2290-27, February 1977.

93. G. Vermes, Westinghouse, personal communication to A. P. Fraas, Mar. 7, 1978.

94. R. Chamberlin, Westinghouse, personal communication to A. P. Fraas, Mar. 7, 1978.

95. J. Mogul, Curtiss-Wright Corp., personal communication to A. P. Fraas, Feb. 28, 1978 . 
Appendix A

SUMMARY OF LITERATURE CONCERNING THE RESEARCH AND DEVELOPMENT EFFORT ON OPEN-CYCLE COAL-FIRED GAS TURBINES

The industrial application of gas turbine drives for process compressors and electric generators began in the early thirties and had gained general acceptance by the late forties. ${ }^{5-7}$ These turbines usually operated with relatively clean fuels, such as natural gas or distillate oils. In the mid-forties and early fifties, investigations directed toward the industrial applications of gas turbines supplied with a gas containing a high solids loading were undertaken. ${ }^{30-38}$ The solids were introduced into the gas stream by one of two methods. The first involved a gas turbine located in a process stream, such as a turbine receiving gas from a catalytic cracker. ${ }^{37,38}$ The second method involved the direct firing of a high-ash fuel such as coal. ${ }^{30-36}$

The problems associated with the direct firing of coal in an open-cycle gas turbine were investigated over a 26-year period (1944-1970) by the Locomotive Development Committee of Bituminous Coal Research, Inc., in the United States and by the Aeronautical Research Laboratories in Austra1ia. 8,33

\section{Locomotive Development Committee}

Houdry 5-stage reaction turbine

A Houdry process turbine built by Allis-Chalmers Company during World War II for use in Russian refineries and transferred as war surplus to the U.S. Bureau of Mines was lent to the LDC to serve as the first full-scale coal-fired gas turbine plant. The unit was installed and began coal-fired nperation on November $7,1949$.

The Houdry plant consisted of an Allis-Chalmers type VA 820, 20-stage axial compressor rated at $39 \mathrm{psig}(0.37 \mathrm{MPa})$ at $5180 \mathrm{rpm}$ when handling $46,600 \mathrm{cfm}\left(22 \mathrm{~m}^{3} / \mathrm{sec}\right)$ of inlet air at $60^{\circ} \mathrm{F}\left(15.6^{\circ} \mathrm{C}\right)$ and 14.7 psia $(0.1$ $\mathrm{MPa}) .{ }^{11,12}$ The compressor was driven by a 5-stage reaction turbine that produced $6200 \mathrm{hp}(4625 \mathrm{~kW})$ at $5180 \mathrm{rpm}$ with an inlet temperature of $950^{\circ} \mathrm{F}$ $\left(510^{\circ} \mathrm{C}\right)$. 
The following description of the operation of the Houdry plant was taken from Ref. 12:*

The compressor raises the pressure of the air to about 53.5 psi $(0.37 \mathrm{MPa})$ absolute, heating it in the process to $370^{\circ} \mathrm{F}\left(188^{\circ} \mathrm{C}\right)$. About $5600 \mathrm{hp}(4175 \mathrm{~kW})$ is required to compress the 206,000 $1 \mathrm{~b}$ $(93,400 \mathrm{~kg})$ of air taken into the system each hour.

As the air leaves the compressor, the stream is divided into the tempering air line, which takes $113,000 \mathrm{lb} / \mathrm{hr}(51,000 \mathrm{~kg} / \mathrm{hr})$ and the combustion air supply line. The mixture of combustion air and coal is heated to $1300^{\circ} \mathrm{F}\left(705^{\circ} \mathrm{C}\right)$ by burning approximately $20001 \mathrm{~b}(907 \mathrm{~kg})$ of pulverized coal per hour in the coal combustor. This stream then passes through the louver separator, where the larger ash particles are concentrated into a smaller air stream $[5000 \mathrm{lb} / \mathrm{hr}(2300 \mathrm{~kg})]$ and blown out of the system. I'he 1 nuver also equalizes the temperature across the stream.

Separation of the fine ash is accomplished by a battery of 18 American Blower Corporation type ST-361 tubes. The air and dust are rotated by a spinner at the entrance to each tube which is used to carry the dust away, while the main stream, now free of the large dust particles, passes on to the turbine.

The secondary air stream must also be cleaned and returned to the turbine. This is accomplished by taking the secondary flow from the 18 primary collector tubes through 3 secondary collectors, where the dust in the original $10 \%$ secondary flow is further concentrated to a $1 \%$ stream which carries the ash out through a blowdown nozzle. The remaining $9 \%$ will be returned to the main air flow on its way to the turbine.

The remaining $77,0001 \mathrm{~b}(35,000 \mathrm{~kg})$ of air at $1300^{\circ} \mathrm{F}\left(705^{\circ} \mathrm{C}\right)$ is now diluted by the addition of the $113,0001 \mathrm{~b}(51,000 \mathrm{~kg})$ of $370^{\circ} \mathrm{F}\left(188^{\circ} \mathrm{C}\right)$ air coming through the tempering line. l'he resulting mixture, $190,000 \mathrm{lb} / \mathrm{hr}(86,000 \mathrm{~kg} / \mathrm{hr})$, enters the turbine at $740^{\circ} \mathrm{F}\left(394^{\circ} \mathrm{C}\right)$, where it does just enough work to drive the compressor at full speed.

Four 250-hr tests of the Houdry unit were conducted during the 195051 period. The description and analysis of the results of these tests given below are summaries of data given in Refs. 13 through 16.

Inopoction of the turbine after the lirst 250 hr of r.nal-fired operation revealed erosion in several sections of the first row of stator blading. The erosion was most pronounced in the upper half of the casing, between 12 and 2 o'clock. The rotor blades suffered no damage of any importance except for a number of nicks on the leading edges of the first

* The metric equivalent of all units have been added to direct quotes for clarity for the reader. 
blade row, indicating that many large ash fragments had passed through the ash separator.

The first-row stator blading was also eroded badly near the lashing wire, about 1 in. from the blade tip. Bends in the inlet gooseneck and the sharp changes of direction at the first-stage entrance apparently concentrated the ash and caused the localized erosion.

A shield was installed at the turbine inlet to deflect the ash stream and distribute it more uniformly around the turbine inlet for the second 250-hr test. The change was ineffective. The erosion continued on the first-row stator blading and extended to the first-row rotor blading.

The first-row stator (with the lashing wires omitted) and rotor blading were replaced after the second 250-hr test. Also the ash separator design was changed in an effort to improve the quality of the turbine inlet gas stream. The third 250-hr test resulted in much more severe erosion than had been found previously. The first-row stator blading was again severely eroded between 10 and 2 o'clock, and the second and third rows of stator blading suffered severe erosion damage. The rotor blading showed no evidence of damage other than polishing.

For the fourth 250-hr test, the first three rows of stator blades were replaced. The lashing wire was restored to the first row of stator blades to avoid the vibration which had been noted in the third $250-\mathrm{hr}$ run. A new design ash separator was installed. Careful inspection of the blades at the end of the test showed that only very slight traces of erosion existed in the stator blading. The rotor blading (the first row had $500 \mathrm{hr}$ of service and rows two through four had $1000 \mathrm{hr}$ ) was in excellent shape, with the only noticeable change being a slight thinning and sharpening of the blade tips.

Representative subsieve analyses of the turbine and separator inlet dust samples taken during the four 250-hr runs are given in Table A.1.13 Deposits were encountered for the first time during the fourth $250-\mathrm{hr}$ test, when a deposit built up on the trailing edge of the last row of rotor blades. The deposit extended from about $1 \mathrm{in}$. $(2.5 \mathrm{~cm})$ beyond the roots of the blades out to about $1.5 \mathrm{in} .(3.8 \mathrm{~cm})$ from the tips. The deposit was first noticed after about $50 \mathrm{hr}$ of the fourth test period. The deposited material was relatively soft and easily removed and contained $72 \%$ carbon. 
Table A.1. Subsieve analyses of turbine inlet dust from four $250-\mathrm{hr}$ coal-burning tests at $740^{\circ} \mathrm{F}\left(393^{\circ} \mathrm{C}\right)$

\begin{tabular}{|c|c|c|c|c|c|}
\hline \multirow{2}{*}{$\begin{array}{c}\text { Particle } \\
\text { size } \\
(\mu)\end{array}$} & \multirow{2}{*}{$\begin{array}{l}\text { Separator } \\
\text { inlets } \\
1 \text { thru } 4^{a}\end{array}$} & \multicolumn{4}{|c|}{ Separator outlet } \\
\hline & & 1 & 2 & 3 & $4^{a}$ \\
\hline-10 & 47.0 & 57.7 & 69.1 & 40.7 & 84 \\
\hline$+10-20$ & 29.4 & 34.5 & 26.3 & 37.7 & 29.4 \\
\hline$+20-40$ & 19.2 & 6.5 & 2.0 & 16.9 & .2 .1 \\
\hline+40 & 4.4 & 1.3 & 2.6 & 4.7 & \\
\hline Tota]. +10 & 53.0 & 42.3 & 30.9 & 59.3 & 16.0 \\
\hline Total +20 & 23.6 & .7 .8 & 4.6 & 21.6 & 2.1 \\
\hline
\end{tabular}

\section{Allis-Chalmers 6-stage reaction turbine}

A coal-burning gas turbine designed by Allis-Chalmers for railroad service was installed in the LDC test facility at Dunkirk, New York, in late 1951. The following description of the installation was taken from Ref. 17.

The turbine designed and built by Allis-Chalmers is a sixstage reaction machine operating at $5700 \mathrm{rpm}$ with a maximum inlet temperature of $1300^{\circ} \mathrm{F}\left(705^{\circ} \mathrm{C}\right)$. The rotor was machined from a forging of Timken alloy (16-25-6); the cylinder blading was precision cast from S-590, while the rotor blades were forged and final machined from the same alloy. The turbine casing was fabricated from 19-9-DL. At maximum load, $60^{\circ} \mathrm{F}$ $\left(16^{\circ} \mathrm{C}\right)$ Inlet air, turbine develops $16260 \mathrm{hp}(12120 \mathrm{~kW})$, compressor takes $11750 \mathrm{hp}(8760 \mathrm{~kW})$, plant delivers $4350 \mathrm{hp} \mathrm{(3240}$ $\mathrm{kW})$ at shaft. Turbine efficiency averaged $87.5 \%$ from idling to full load.

The compressor is a 21 stage axial flow machine, designed and built by Allis-Chalmers. Tests show full speed capacity of $65,000 \mathrm{cfm}\left(30.7 \mathrm{~m}^{3} / \mathrm{sec}\right)$, with test efficiency ranging from 82 to $86 \%$.

Figure A.1 shows the turbine inlet and outlet temperatures as a function of the turbine shaft horsepower. ${ }^{16}$ The compositions of the alloys used in the turbine are given in Table A.2, ${ }^{15}$ and gas velocities relative to the turbine blades are given in Table A.3. ${ }^{31}$ 


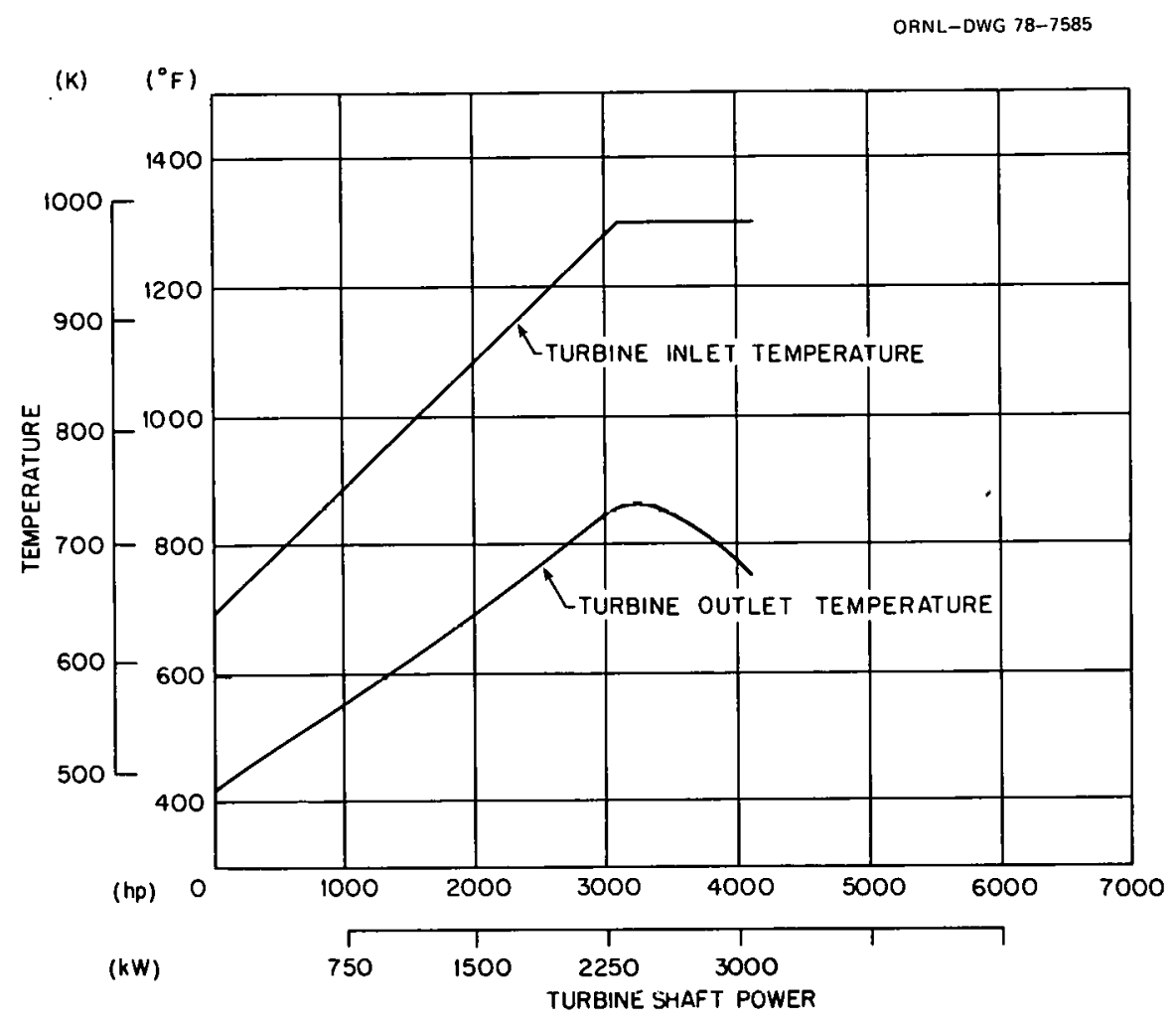

Fig. A.1. Locomotive Development Committee six-stage turbine inlet and outlet temperatures. Compressor inlet $80^{\circ} \mathrm{F}\left(300^{\circ} \mathrm{K}\right)$ at $14.7 \mathrm{psia}(0.1$ $\mathrm{MPa}$ ) (Ref. 16).

Table A.2. Composition of alloy steels used in the coal-fired gas turbine (Ref. 15)

\begin{tabular}{|c|c|c|c|c|c|}
\hline \multirow{2}{*}{ Element } & \multicolumn{5}{|c|}{ Percent element in alloy - } \\
\hline & $5-990$ & 19-9-DL & $\begin{array}{l}\text { Timken } \\
16-25-6\end{array}$ & $113-31$ & GRM-235 \\
\hline Iron & 24.6 & 67.2 & 49.0 & $2.00 \max$ & $8.0-12.0$ \\
\hline Chromium & 20.0 & 19.0 & 16.0 & $23.0-28.0$ & $14.0-17.0$ \\
\hline Nickel & 20.0 & 9.0 & 25.0 & $9-0-12.0$ & Balance \\
\hline Cobalt & 20.0 & & & Balance & \\
\hline Molybdenum & 4.0 & 1.25 & 6.5 & & $4.5-6.0$ \\
\hline Tungsten & 4.0 & 1.25 & & $6.0-9.0$ & \\
\hline Manganese & 0.75 & 0.75 & $1 . .5$ & & $0.25 \max$ \\
\hline Silicon & 0.65 & 0.5 & $0: 75$ & & $0.60 \max$ \\
\hline Columbium & 4.0 & 0.4 & & & \\
\hline Titanium & & 0.35 & & & $1.5-2.5$ \\
\hline Carbon & 0.4 & 0.3 & 0.09 & $0.45-0.60$ & $0.10-0.20$ \\
\hline Aluminum & 1.64 & & & & $2.5-3.5$ \\
\hline Nitrogen & & & 0.15 & & \\
\hline Bóron & & & & & $0.025-0.100$ \\
\hline
\end{tabular}


Table A.3. Gas velocities relative to blading for LDC design (Ref. 31)

[Six-slage turblne, $5700 \mathrm{rpm}, 1300^{\circ} \mathrm{F}\left(705^{\circ} \mathrm{C}\right)$ inlet tellperalure, 71.0 psia $(0.47 \mathrm{MPa})$ inlet pressure, 15.06 psia $(0.1 \mathrm{MPa})$ exhaust pressure, $233,220 \mathrm{lb} / \mathrm{hr}(28 \mathrm{~kg} / \mathrm{sec})$ flow]

\begin{tabular}{|c|c|c|c|c|c|c|c|}
\hline & \multirow[b]{2}{*}{ Stage } & \multicolumn{2}{|c|}{ Blade root } & \multicolumn{2}{|c|}{ Blade midsection } & \multicolumn{2}{|c|}{ Blade tip } \\
\hline & & $\begin{array}{l}\text { Velocity } \\
\text { (fps) }\end{array}$ & $\begin{array}{l}\text { Distance } \\
\text { from.center } \\
\text { of rotor } \\
(1 \mathrm{n} .)\end{array}$ & $\begin{array}{l}\text { Velocity } \\
\text { (fps) }\end{array}$ & $\begin{array}{l}\text { Distance } \\
\text { from center } \\
\text { of rotor } \\
\text { (in.) }\end{array}$ & $\begin{array}{l}\text { Velocity } \\
\text { (fps) }\end{array}$ & $\begin{array}{l}\text { Distance } \\
\text { from center } \\
\text { of rotor } \\
\text { (in.) }\end{array}$ \\
\hline 1 . & $\begin{array}{l}\text { Stator inlet } \\
\text { Stator exit } \\
\text { Rotor inlet } \\
\text { Rotor exit }\end{array}$ & $\begin{array}{r}430 \\
1000 \\
585 \\
764\end{array}$ & 10.0 & $\begin{array}{l}428 \\
893 \\
465 \\
826\end{array}$ & 11.79 & $\begin{array}{l}426 \\
804 \\
405 \\
892\end{array}$ & 13.58 \\
\hline 2. & $\begin{array}{l}\text { Stator inlet } \\
\text { Stator exit } \\
\text { Rntor inlet } \\
\text { Rotor exit. }\end{array}$ & $\begin{array}{r}430 \\
1000 \\
585 \\
764\end{array}$ & 10.0 & $\begin{array}{l}427 \\
872 \\
441 \\
839\end{array}$ & 12.14 & $\begin{array}{l}425 \\
780 \\
402 \\
913\end{array}$ & 14.28 \\
\hline 3. & $\begin{array}{l}\text { Stator inlet } \\
\text { Stator erit } \\
\text { Rotor inlet } \\
\text { Rotor exit }\end{array}$ & $\begin{array}{r}430 \\
1000 \\
545 \\
764\end{array}$ & 10.0 & $\begin{array}{l}427 \\
853 \\
432 \\
853\end{array}$ & 12.51 & $\begin{array}{l}422 \\
15 \% \\
405 \\
937\end{array}$ & 15.01 \\
\hline 1. & $\begin{array}{l}\text { Stator inlet } \\
\text { Stator exit } \\
\text { Rotor inlet } \\
\text { Rotor ex1t }\end{array}$ & $\begin{array}{r}430 \\
1000 \\
585 \\
764\end{array}$ & 10.0 & $\begin{array}{l}427 \\
834 \\
417 \\
869\end{array}$ & 12.93 & $\begin{array}{l}419 \\
733 \\
419 \\
963\end{array}$ & 15.85 \\
\hline 5. & $\begin{array}{l}\text { Stator inlet } \\
\text { Stator exit } \\
\text { Rotor inlet } \\
\text { Rotor exit }\end{array}$ & $\begin{array}{r}430 \\
1000 \\
385 \\
764\end{array}$ & 10.0 & $\begin{array}{l}426 \\
812 \\
407 \\
887\end{array}$ & 13.42 & $\begin{array}{l}415 \\
710 \\
443 \\
983\end{array}$ & 16.83 \\
\hline 6. & $\begin{array}{l}\text { Stator inlet } \\
\text { Stator cxit } \\
\text { Rotor inlet } \\
\text { Rotor exit }\end{array}$ & $\begin{array}{r}430 \\
1000 \\
585 \\
764\end{array}$ & 10.0 & $\begin{array}{l}425 \\
790 \\
400 \\
905\end{array}$ & 14.00 & $\begin{array}{r}410 \\
680 \\
490 \\
1030\end{array}$ & 18.0 \\
\hline
\end{tabular}

The turbine was first run on coal in September 1951. A description of the test is taken from Ref. 17:

As soon 28 the acceptance test had been successfully completed, the fuel controls were turned from "Oil" to "Coal" and the plant was operated for a total of 178 hours on Pittsburgh seam high volatile bituminous coal. The machine operated as . well with coal as with oil, and, in general, it was impossible for a casual observer to tell whether the plant wac burning oil or coal. The stack was relatively clear and the ash disposal system worked satisfactorily. Combustion efficiency, as determined by ash analysis, was consistently above 95 percent. Trouble was encountered with damp coal and a number of alteratinns had to be made in the conl systelin. The wlelth of the coal feed-pump rotor had to be increased to $5.0 \mathrm{in} .(12.7 \mathrm{~cm})$, and the method of venting the pump was altered. The duration of the coal-fired tests ranged from a few hours to a maximum of 43 hours. 
This preliminary $178 \mathrm{hr}$ of operation was carried out with a pilot oil burner in each combustor, and the maximum load carried for any significant period of time was $2000 \mathrm{hp}(1492 \mathrm{~kW})$ at a turbine inlet temperature of $1060^{\circ} \mathrm{F}\left(571^{\circ} \mathrm{C}\right) .19$

Figures A.2 and A.3 are photographs of the turbine rotor which were taken as soon as the cover had been lifted. The blades are entirely free from deposits and erosion. A slight discoloration of the last row of blades, extending inward about $0.5 \mathrm{in}$. from the tips, was the only indication that the turbine had been running on heated air. ${ }^{20}$

Experience with the Houdry unit had led to the expectation that erosion might be encountered in the stator blading, but a careful examination of the entire turbine showed only one very small spot of erosion. Figure A. 4 shows the appearance of the upper half of the first row stator blading as seen from the inlet end. There is some brightening of the leading edges, but the only erosion was that on the two blades located at 12 o'clock, as shown in Fig. A.5. There were no deposits of ash anywhere in the turbine, and the labyrinth seals were all perfectly clean. ${ }^{17}$

The combustor was modified to eliminate the oil pilot flame, and the turbine was operated for an additional $757 \mathrm{hr}$ at an average turbine inlet temperature of $1225^{\circ} \mathrm{F}\left(663^{\circ} \mathrm{C}\right) .{ }^{21}$ During the first $71 \mathrm{hr}$ of operation, a leak developed within the flyash separator and resulted in a large amount of coarse ash passing through the turbine, seriously eroding the first-row stator blading. ${ }^{19}$ The leak was repaired and the test continued, but the turbine gradually lost power and there was a major reduction in power output from 625 to $757 \mathrm{hr}$. The test was terminated and the equipment dismantled for inspection. Erosion was noted on the trailing edges of the first five rows of rotor and stator blading, being progressively less toward the low-pressure end of the turbine. The sixth row of blading was only slightly eroded. No significant ash deposition was found on the turbine blading. ${ }^{22,23}$

Ash in the combustion gases driving the turbine was sampled at the turbine inlet and at the exhaust. About $40 \mathrm{lb} / \mathrm{hr}(18.2 \mathrm{~kg} / \mathrm{hr})$ of ash entered the turbine when the separation system was functioning at maximum effectiveness. The size distribution of the ash was approximately $2 \%$ plus 


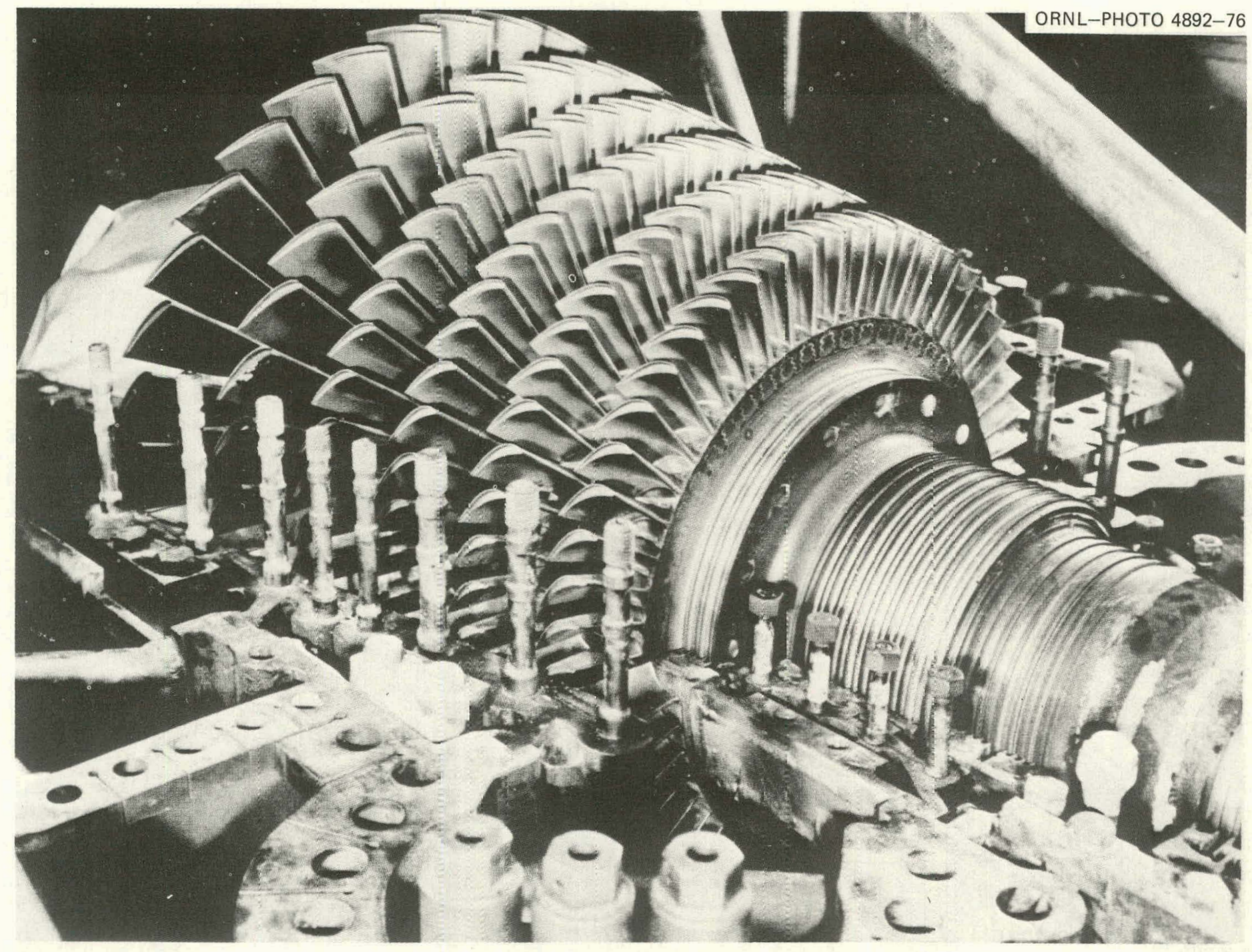

Fig. A.2. General view of locomotive turbine rotor, left side (Ref. 18). 


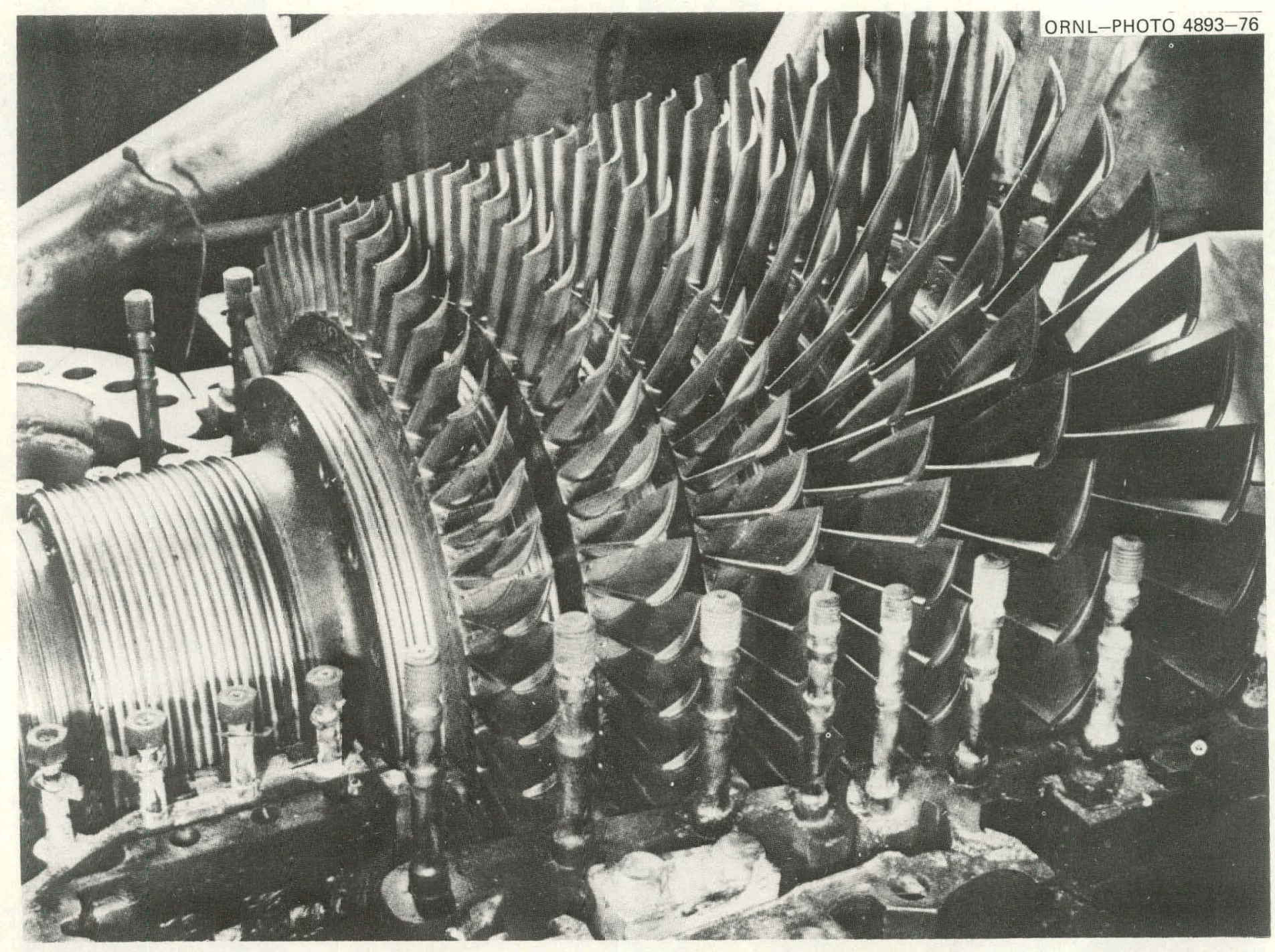

Fig. A.3. General view of locomotive turbine rotor, right side (Ref. 18). 


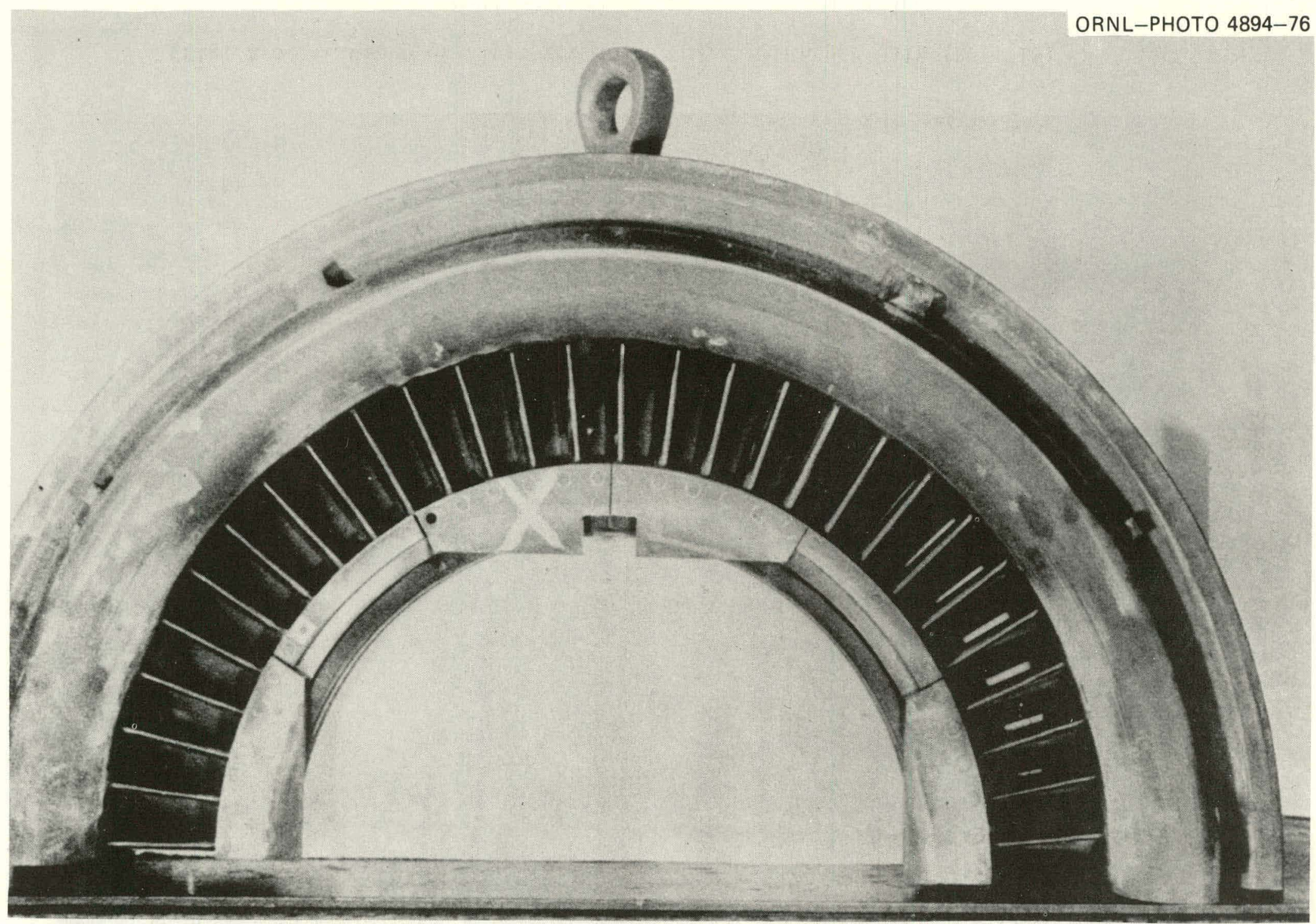

Fig. A.4. Front view of turbine stator blading, upper half (Ref. 18). 


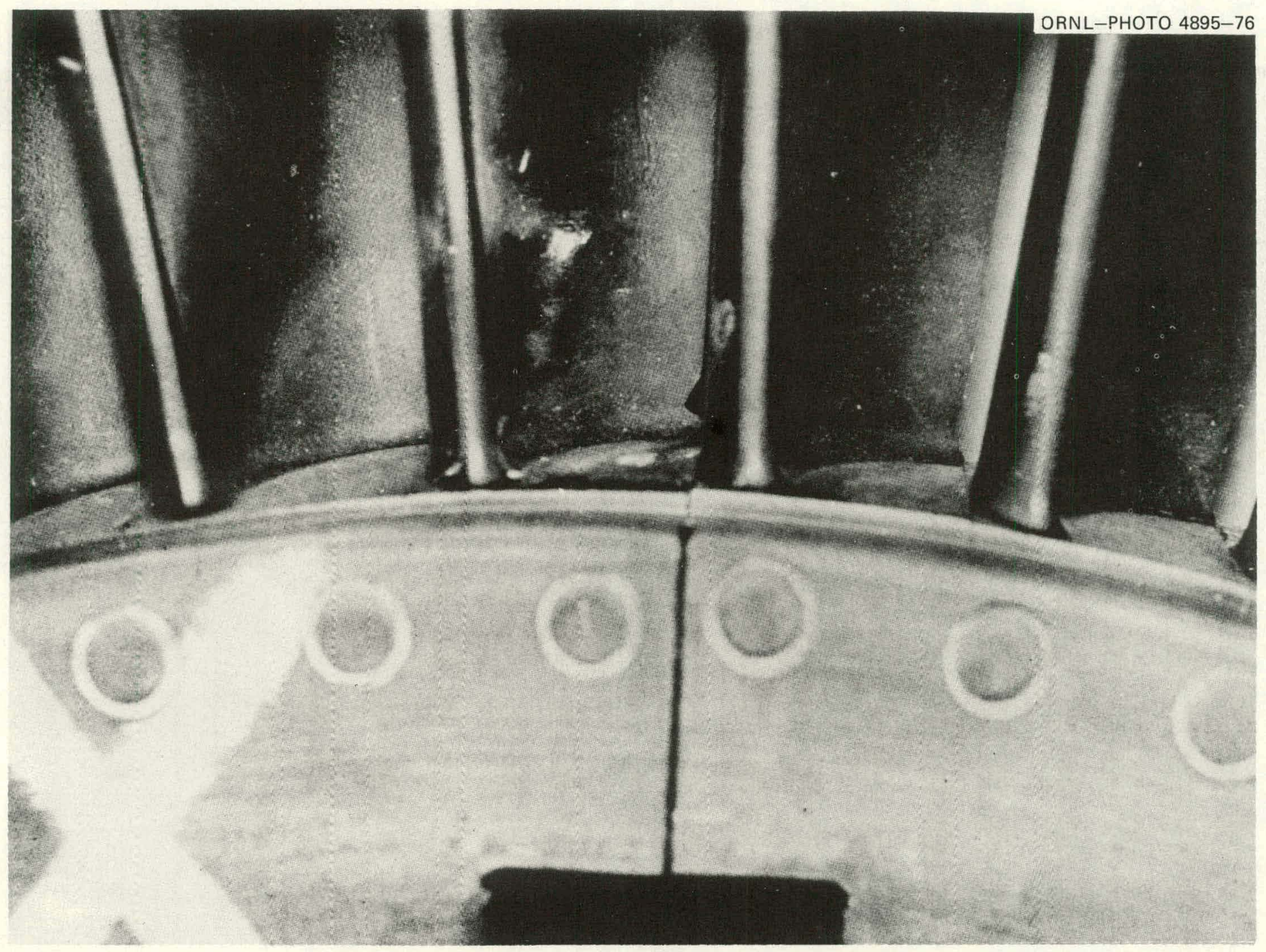

Fig. A.5. Closeup of first-row stator blading, upper half (Ref. 18). 
$20 \mu \mathrm{m}$ and $15 \%$ plus $10 \mu \mathrm{m}$. Performance of the separator frequently deteriorated during the 757-hr test, increasing both the amount and size of the ash entering the turbine. Gas from the exhaust contained virtually no plus 10- $\mu \mathrm{m}$ ash particles, indicating that the turbine had pulverized the particles as they struck the blades. ${ }^{22,31}$

After the 757-hr test, the first four rows of rotor blades were replaced with blades of 19-9DL steel (Table A.2). The first four rows of stator blades were replaced with S-590 alloy, but the last two rows of rotor and stator blades were not changed. The regenerator was removed, and the combustor-to-separator path was lengthened by about $8 \mathrm{ft}(2.44 \mathrm{~m})$. The turbine was operated at $1060^{\circ} \mathrm{F}\left(571^{\circ} \mathrm{C}\right)$ inlet temperature and $4500 \mathrm{rpm}$ for runs totaling $301 \mathrm{hr}$, and the ash separator functioned effectively throughout. Ash particles were rarely present in amounts greater than $1 \%$ plus $20 \mu \mathrm{m}$ and $10 \%$ plus $10 \mu \mathrm{m}$. The first four stages of rotor blades did not erode, and erosion of the last two rows of rotor blades did not advance beyond that noted at the end of the 757-hr test. The stator blades were also free of erosion. ${ }^{25}$

Figures A. 6 and A.7 are photographs of the turbine rotor taken as soon as the cover had been lifted. No ash deposits can be seen, although there is a thin layer of scale on the convex surfaces of the first row of blades. ${ }^{25}$ Figure A.8 is a front view of the first-row stator blades. The insert is a closeup of the blades at 12 o'clock, which shows two small nicks that represent the only measurable erosion in the entire turbine. ${ }^{25}$ Comparison of Fig. A.5, taken at the same location after the 178-hr tests, with Fig. A.8 indicates an almost identical nick that also represented the only measurable erosion in the entire turbine.

For comparison of the erosion in the first $316 \mathrm{hr}$ of the $757-\mathrm{hr}$ tcot with the 300-hr test, photographs of the first row stator blading taken at various times are shown in Fig. A.9. ${ }^{25}$ Parts $a$ to $c$ apply to the 757hr test, and parts $d$ to $f$ apply to the 300-hr test. Figure A.9a was taken after $71 \mathrm{hr}$ of operation at an average turbine inlet temperature of $1050^{\circ} \mathrm{F}$ $\left(546^{\circ} \mathrm{C}\right) .{ }^{24}$ As mentioned earlier, during this period of operation a leak developed within the flyash separator and large quantities of coarse ash entered the turbine, resulting in serious erosion. ${ }^{25}$ Figure A.9b was taken $124 \mathrm{hr}$ later. During this period the turbine was operated with an average 


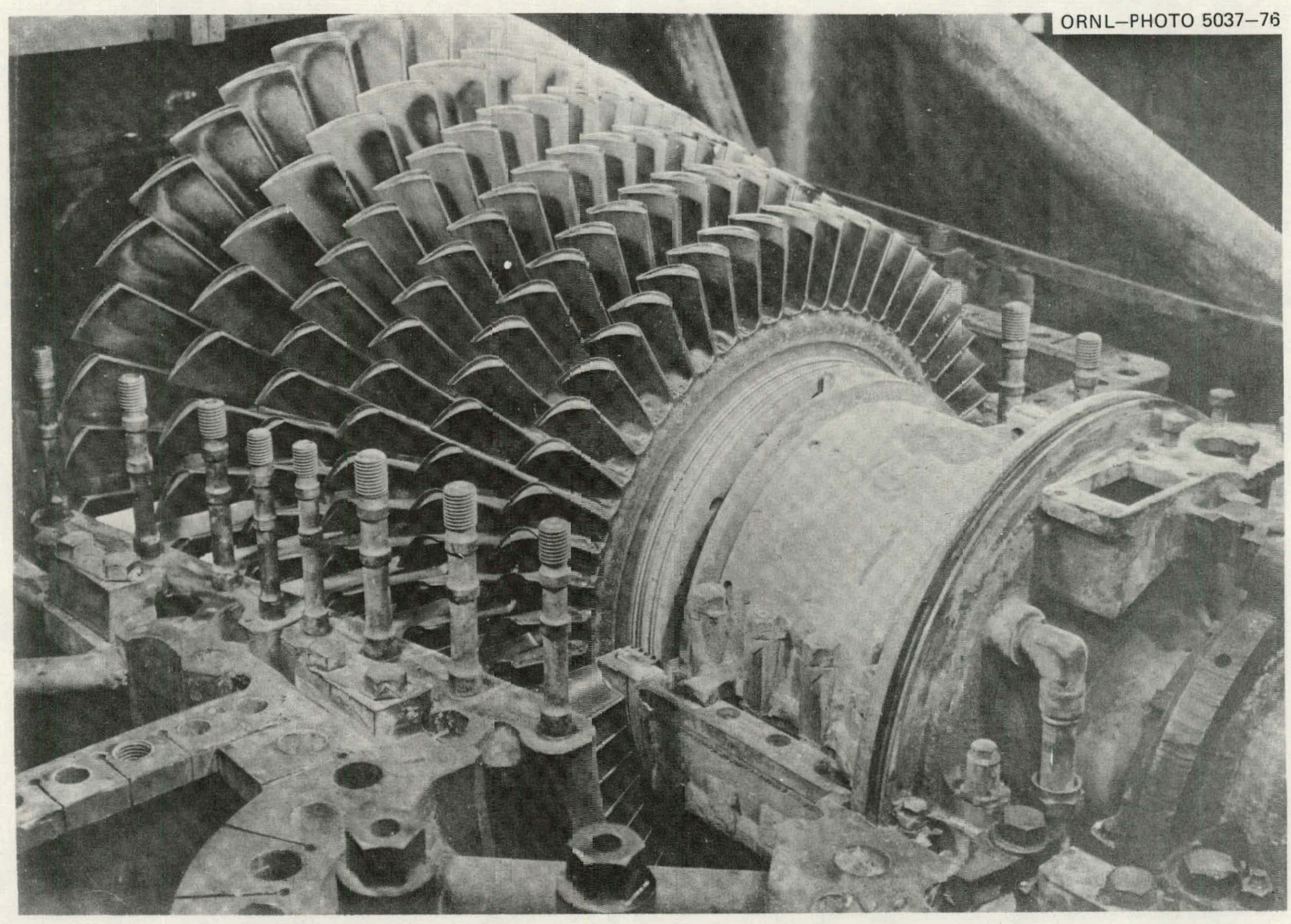

Fig. A.6. Turbine rotor after 300-hr test, view from left side (Ref. 23). 


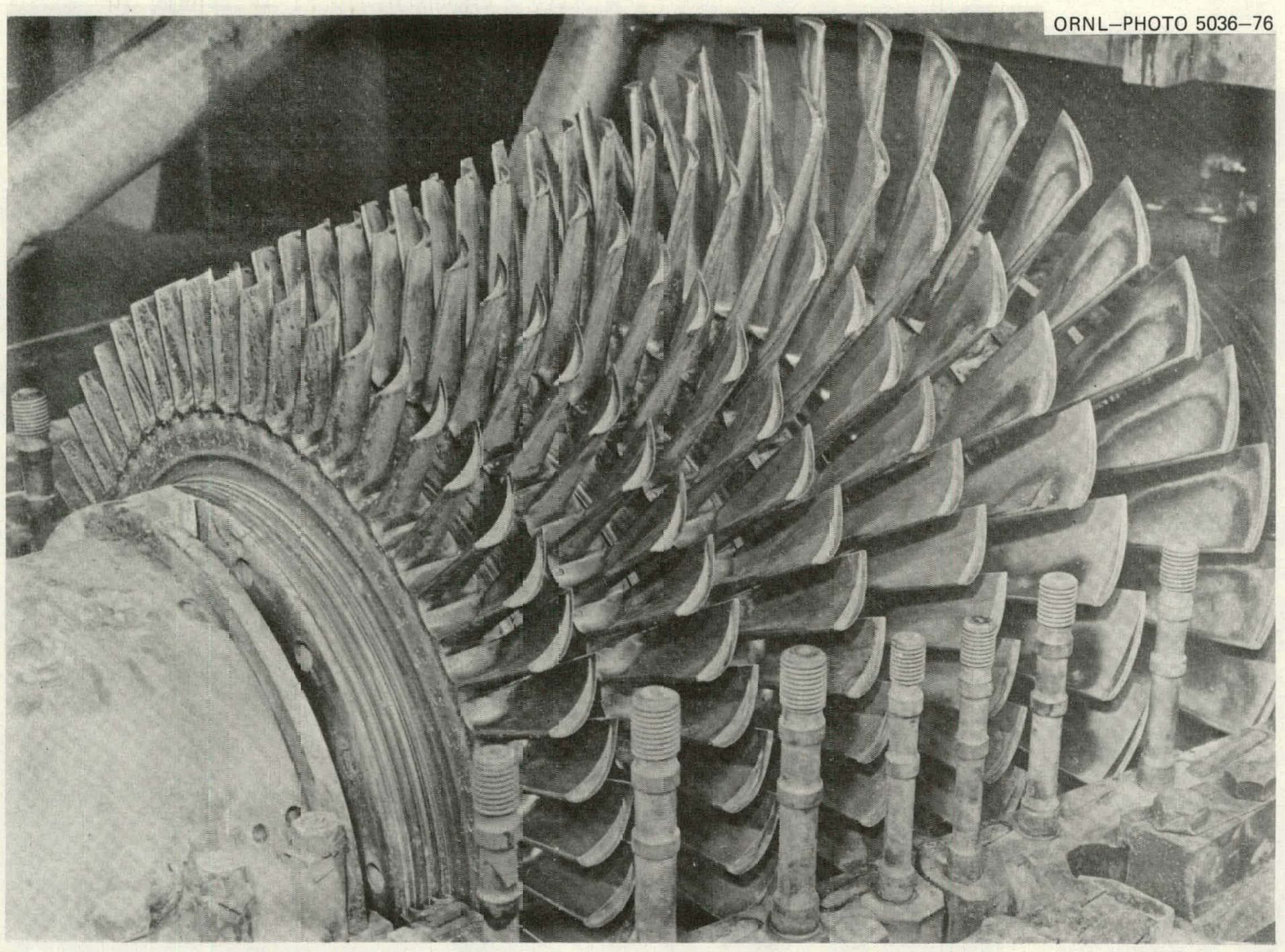

Fig. A.7. Turbine rotor after 300-hr test, view from right side (Ref. 23). 


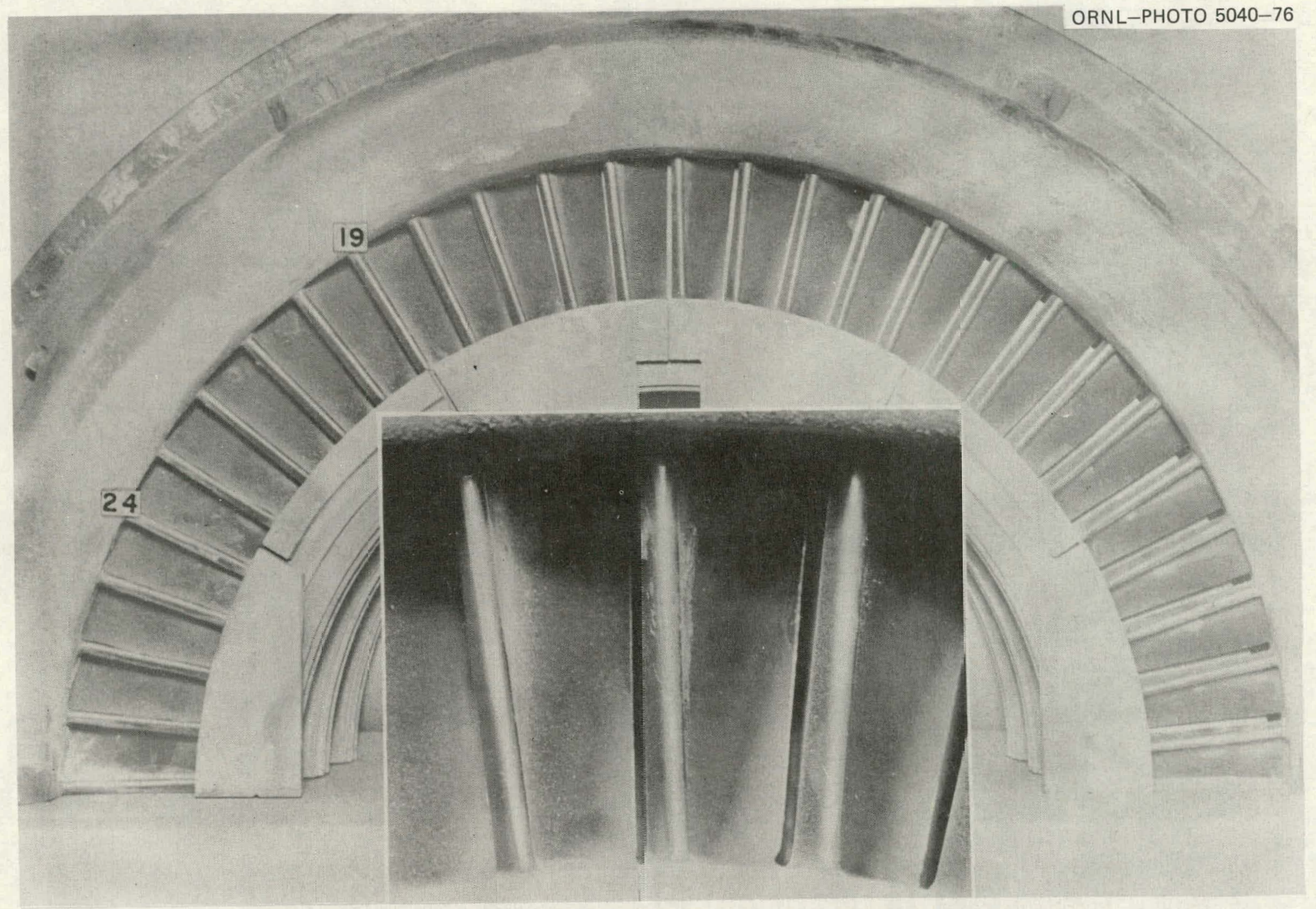

Fig. A.8. Front view of first-row stator blades. Insert shows closeup of blades at 12 o'clock (Ref. 23). 

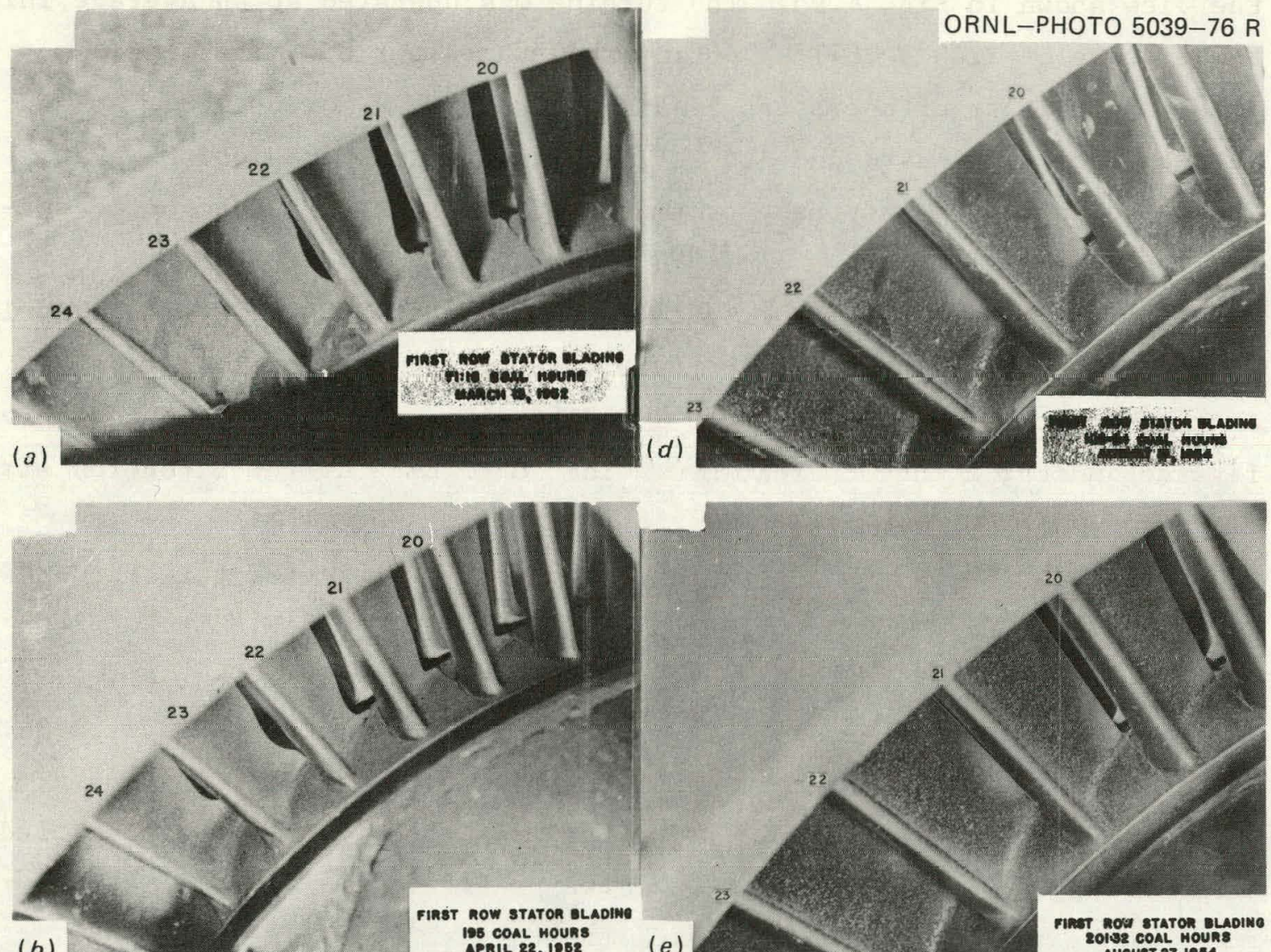

(b) 105 COAL MOURS
APRIL 22,1062 (e)
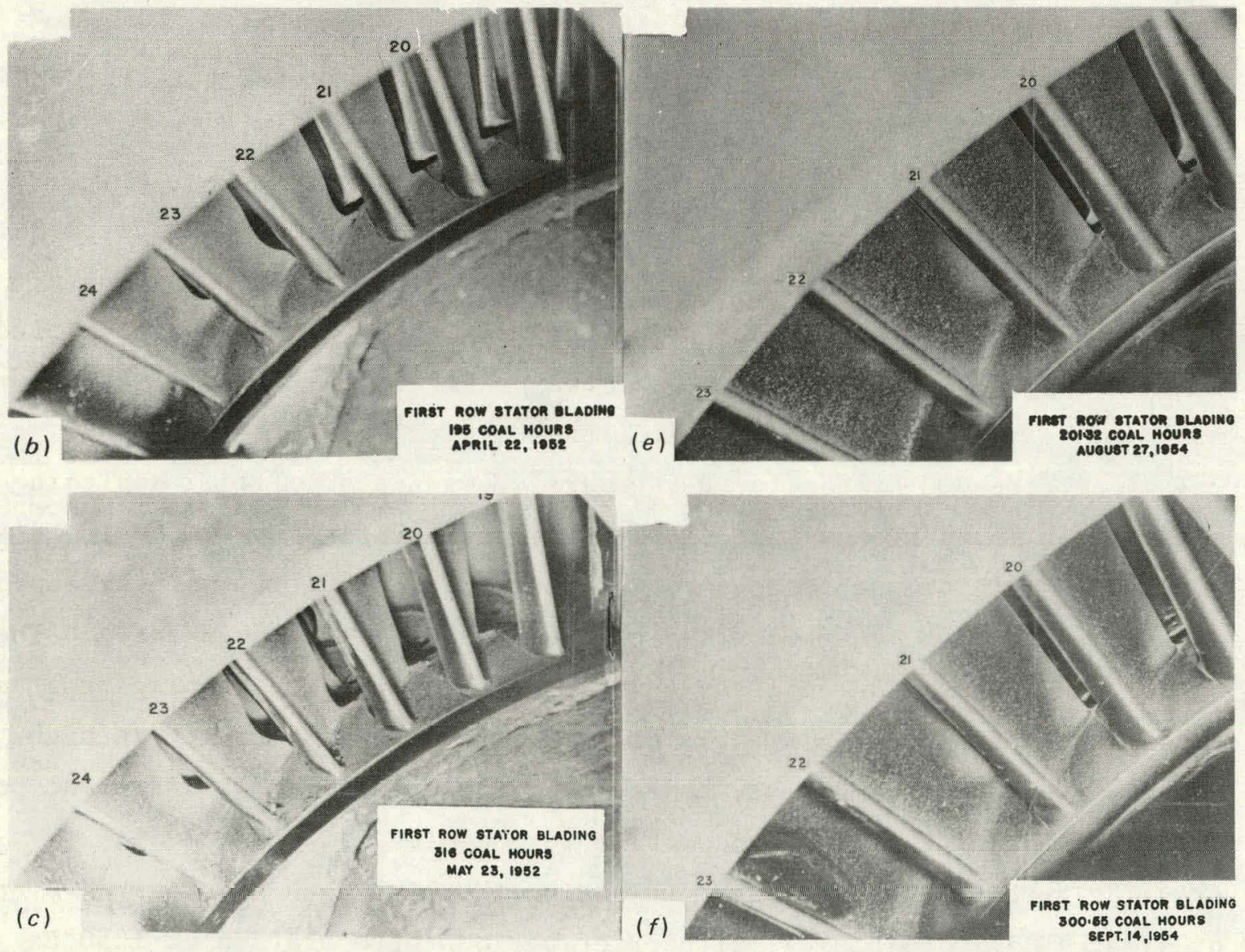

FIRST $316 \mathrm{hr}$ OF $750-\mathrm{hr}$ TEST (REF. 23)

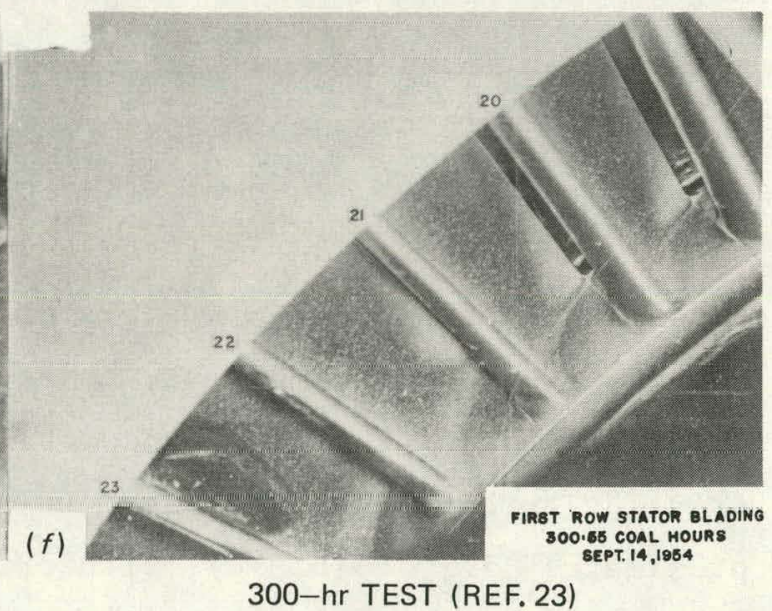

Fig. A.9. First-row stator blading condition after testing. 
inlet temperature of $1160^{\circ} \mathrm{F}\left(627^{\circ} \mathrm{C}\right)$. Figure A.9c was taken $121 \mathrm{hr}$ after the view shown in Fig. A.9b. The turbine was operated at an average inlet temperature of $1240^{\circ} \mathrm{F}\left(671^{\circ} \mathrm{C}\right)$ during this third period. The erosion noted after $71 \mathrm{hr}$ of operation became progressively more severe, as can be seen from Figs. A. $9 b$ and A.9c. The extent of the erosion shown in Fig. A.9c was such that the performance of the turbine had begun to suffer. ${ }^{25}$

Figures A. $9 d$ to A. $9 f$ are photographs taken at 100 -hr intervals during the 300-hr test. ${ }^{25}$ During this test, the turbine was operated with an average inlet temperature of $1060^{\circ} \mathrm{F}\left(571^{\circ} \mathrm{C}\right) .^{24}$ Inspection of these three figures indicates that there was no visible erosion of the first-row stator blading.

Figure A.10a is a photograph of the discharge side of the third-row stator blading taken at the end of the 757-hr test, and Fig. A.10B is a photograph of the same location taken at the end of the 300-hr test. ${ }^{25}$ Figure A.10 a shows the extent to which the third-row stator was eroded. Apparently, the large particles that entered the turbine had not been reduced in size at this point in the turbine. The third-row stator blading shown in Fig. A.10b after the 300-hr test was found by micrometer measurements to be virtually unchanged from the original installation. ${ }^{25}$

After the 300-hr test, the regenerator was reinstalled. Replacing the regenerator moved the combustors back to their original position immediately ahead of the flyash separator and shortened the combustion path by approximately $12 \mathrm{ft}(3.66 \mathrm{~m})$ as compared to the $300-\mathrm{hr}$ test arrangement. ${ }^{26}$ The system was operated on rnal for a total of $1421 \mathrm{hr}$. The testing pruyrain consisted of two parts. First, the system was run continually at high power for a period of $852 \mathrm{hr}$, and then it was run $569 \mathrm{hr}$ at different power levels to simulate various locomotive load cycles. ${ }^{27}$

The turbine inlet temperature during the high-load test averaged approximate $1 y=1210^{\circ} \mathrm{F}\left(655^{\circ} \mathrm{C}\right)$, with brief periods of operation at $1250^{\circ} \mathrm{F}$ $\left(677^{\circ} \mathrm{C}\right) .{ }^{26}$. The turbine inlet temperature during the simulated locomotive load cycles averaged approximately $1100^{\circ} \mathrm{F}\left(594^{\circ} \mathrm{C}\right)$, with approximately $50 \%$ of the simulated load cycle having a turbine inlet temperature of approximately $1230^{\circ} \mathrm{F}\left(666^{\circ} \mathrm{C}\right) .^{26}$ The turbine inlet temperature during the simulated locomotive load cycles averaged approximately $1100^{\circ} \mathrm{F}\left(594^{\circ} \mathrm{C}\right)$, with 

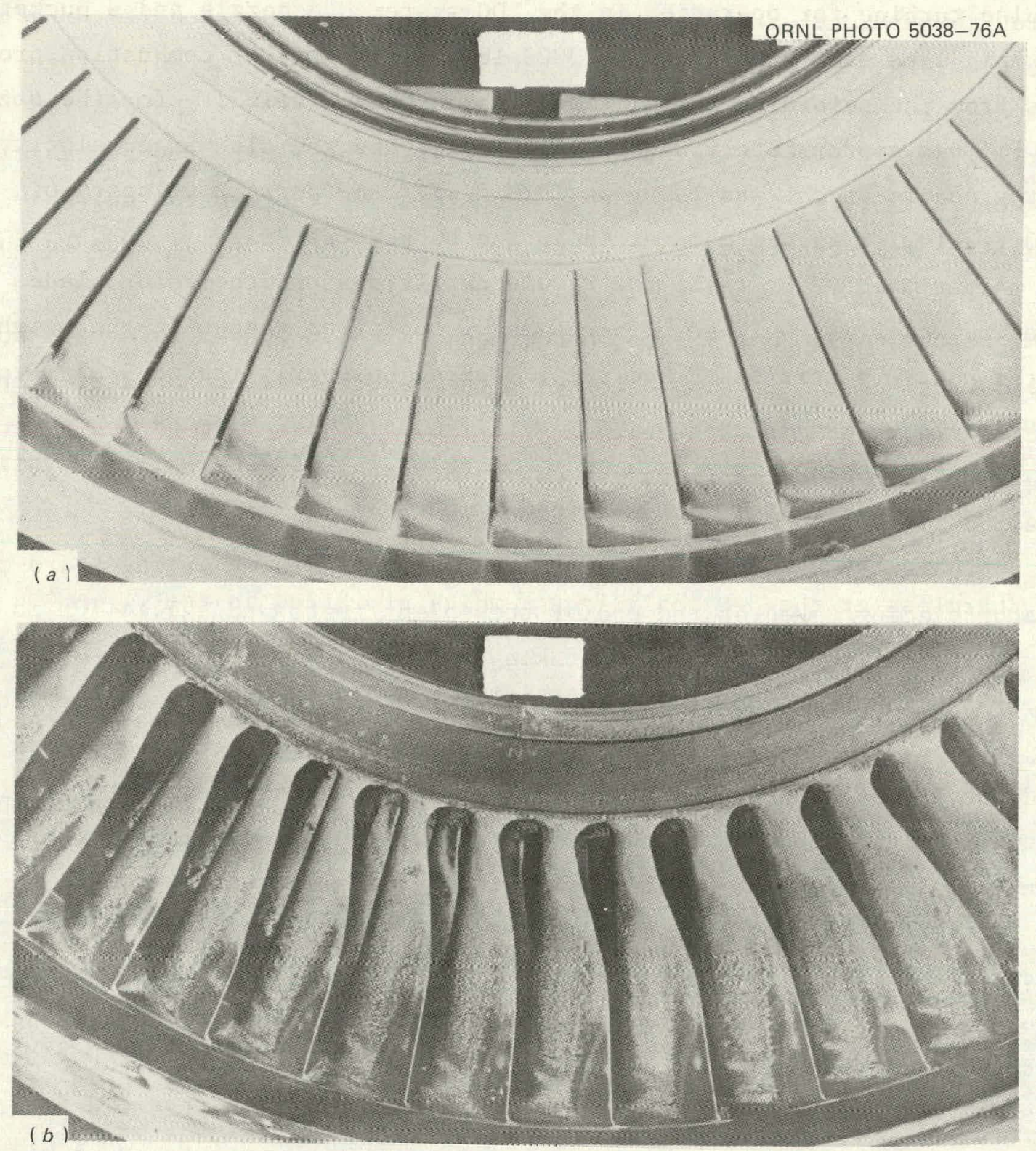

Fig. A.10. Discharge side, third-row stator blad1ng. (d) AL end of $750 \mathrm{hr} ;(\mathrm{b})$ at end of $300 \mathrm{hr}$ test (Ref. 23).

approximately $50 \%$ of the simulated load cycle having a turbine inlet temperature of approximately $1230^{\circ} \mathrm{F}\left(666^{\circ} \mathrm{C}\right) .{ }^{26}$ The size of the ash entering the turbine ran as high as $12 \%$ plus $20 \mu \mathrm{m}$ and $32 \%$ plus $10 \mu \mathrm{m}$.

During the first $907 \mathrm{hr}$ of the 1421-hr test of the turbine, erosion tests were conducted to obtain information as to the suitability of an 
impulse turbine for operation in the LDC system. A nozzle and a bucket test rig were each supplied with $3000 \mathrm{lb} / \mathrm{hr}(380 \mathrm{~g} / \mathrm{s})$ of combustion products from the separator outlet flow. The approach velocity for the nozzle rig was approximately 340 fps $(104 \mathrm{~m} / \mathrm{s})$, and the discharge velocity at the nozzle throat was $1900 \mathrm{fps}(579 \mathrm{~m} / \mathrm{s})$. An approach velocity of $1400 \mathrm{fps}(427 \mathrm{~m} / \mathrm{s})$ was maintained in the bucket test rig.

After the 907-hr test, the nozzle partitions and the rotor blades were inspected and weighed. There was virtually no change in the weight of the nozzle partitions. The rotor blades, however, were severely eroded, especially the concave side.

The conclusion drawn from these tests by the LDC and which is valid only for the particular test conditions is taken from Ref. 26.

The quality of air entering the LDC turbine is relatively harmless at the $340 \mathrm{fps}$ velocity which prevailed in the nozzle test rig. Extremely rapid acceleration to a velocity as high as $1900 \mathrm{fps}(579 \mathrm{~m} / \mathrm{s})$ also caused very little wear on the concave surface of the partition. In the blade test rig, air of the same quality proved to be very erosive at an approach velocity of $1400 \mathrm{fps}(427 \mathrm{~m} / \mathrm{s})$. These facts lead to the conclusion that a multi-stage reaction turbine has a far better chance of operating successfully with coal as its fuel than does an impulse turbine with very high velocities.

After the 1421-hr test, the turbine was opened for inspection. The first-row rotor blades were not seriously. eroded, but the second row suffered wear in a narrow band near the rotor. In addition, small notches were cut in the trailing edges of some blades, and stresses at these notches formed cracks. Semicircular notches were cut in the third row of rotor blades, near the blade roots, and there were cracks near the notches in many of the blades. Wear of the fourth-row blades was similar to that of the third row. Rotor blades in the fifth and sixth rows suffered somewhat more wear than they had during the first test run, but there was no marked change in their condition.

Wear on the stator blades followed approximately the same pattern as that on the rotor blades - a narrow band near the turbine rotor. A second zone of localized wear occurred in a narrow band extending radially inward for approximately $1 / 8 \mathrm{in.}(0.32 \mathrm{~cm})$ at the outer dlameter of the stator blades in the last four stages. 
Light ash deposits were found on the backs of some of the stator blades, but only the third stage had ash coatings thicker than 0.005 in. $(0.13 \mathrm{~mm}) .^{27}$ Normal blade wear was confined to approximately $0.0053 \mathrm{in./}$ $1000 \mathrm{hr}(0.135 \mathrm{~mm} / 1000 \mathrm{hr})$ on the concave surfaces of both the stator and rotor blading. 26

After the 1421-hr test, the turbine was reconditioned and operated on coal for $1103 \mathrm{hr}$. The reconditioning of the turbine included the installation of a deflector ring in front of the base of the first-row stator blades to block the flow of the concentrated stream of dust at this point. Skimmers were installed in the turbine inlet to remove dust concentrated at the concave surface of the turbine inlet.

The first four stages of rotor blad'es were replaced with new blades made of HS-31 and GMR-235 (Table A.2). The last two stages of blades were unchanged, and the stator blading was the same as used in the preceding run, except that the inner stage shroud and seal rings for rows two, three, and four were removed. 28

During the 1103-hr test, the turbine operated with an average load of $2960 \mathrm{hp}(2200 \mathrm{~kW})$, which probably corresponds to an average turbine inlet temperature of approximately 1200 to $1230^{\circ} \mathrm{F}\left(649\right.$ to $\left.666^{\circ} \mathrm{C}\right)$. The size of the ash entering the turbine inlet and passing through the turbine was similar to that of the 1421-hr test. ${ }^{31}$

After completion of the test the turbine was opened for inspection. The first-stage rotor blades were free from erosion. The second, third, and fourth stages were seriously undercut at the base of the leading edge of the blade, but no other serious erosion was noted on the turbine rotor blades. The pressure surfaces of the stator blading were in good condition. The trailing edge of the blades in rows 3 to 6 suffered some erosion, and the ash also cut notches at the outer sidewall base of the leading edges of these blades. ${ }^{31}$

\section{United States Bureau of Mines}

With the completion of the 1103-hr test, the Locomotive Development Committee (LDC) ended its experimental program in 1959. The U.S. Bureau of Mines under a cooperative agreement with Bituminous Coal Research, Inc., 
obtained the LDC turbine and associated equipment for further development. The equipment was moved from Dunkirk, New York, to Morgantown, West Virginia.

The Bureau of Mines contracted with the Gas Turbine Division of the General Electric Company to review the LDC tests and develop a new blade design specifically tailored for a coal-fired turbine plant. A description from the turbine modification recommended by General Electric is excerpted from Ref. 31.

While no single theory uniquely explained the erosion pattern observed in the LDC tests, significant features of the erosion problem were uncovered and described. Two changes were recommended to reduce the rate of erosion. One change was to encourage ash to concentrate at the outer sidewa11, rather than at the roots of the rotor blades. Wear at the rotor blade tips and outer sidewall base of the nonrotating stator blades is less damaging than wear at the base of the highly stressed rotor blades. The second recommendation was the use of titanium carbide wear strips (titanium carbide wears at $1 / 9$ the rate of the Hastelloy-31 blade meta1) at the outer sidewall base of certain stator blades to minimize erosion. Wear strips also were specified for the base of certain rotor blades, in case ash still concentrated at the inner sidewa11.

Detailed changes recommended for the new design contemplated the use of the existing turbine rotor, casing, and inlet hood to minimize the need for extensive modifications to the turbine. Skimmers and deflectors installed in the inlet hood prior to the $1103 \mathrm{hr}$ test were retained since they appeared to have a beneficial effect of the existing inlet as a condition of the new design.

The first major change was the provision of an axial space between the first-stage stator and rotor blades to centrifuge ash particles toward the outer casing by main stream gas flow. This space was provided by removing rotor row 1 and stator row 2 from the six-stage turbine, converting the unit to a fivestage turbine. Calculations indicated that this would clear the inner 1.8 inches of the annulus at the entrance to the Eirst-stage rotor blade of all particles larger than $12 \mu$. The second change involved the design of stator blades to minimize flow separation and end whirls (passage vortex buildup) by the use of new profile shapes and a higher solidity. Blade chords were not changed, but the trailing edges of the blades were reduced to the minimum practicable thickness [.035 in. $(0.89 \mathrm{~mm})]$. These changes were designed to minimize the radial inflow of ash to the Inner diameter. None of the stators, except for the first and fifth stages, were to have inner sidewalls (as in the $1103 \mathrm{hr}$ test). Stator blade tips were specified as 
solid, without rub strips, with tip clearance the same as in the $1103 \mathrm{hr}$ test. This duplicated the conditions of the 1.1.03 hr test, in that there would be the same leakage under the stator tips. The solid tip design, however, was expected to reduce the rate at which the tip clearance increased due to erosion.

The third change called for the inner and outer sidewalls to be stepped, and for titanium carbide wear strips to be installed to take the impact of ash flowing through the clearance at the tips of the stator and rotor blades.

The fourth design feature was that the rotor blades have approximately the same cross sections as used before, except the thickness of the trailing edge was increased to the maximum value [0.120 in. $(3.0 \mathrm{~mm})]$ consistent with turbine efficiency to encourage ash flow radially nutward from the inner diamelér.

Table A.4 from Ref. 31 shows the gas velocities relative to the blading for the new design.

Table A.4. Gas velocities relative to blading for new design (Ref. 31)

[Five-stage turbine, $5700 \mathrm{rpm}, 1300^{\circ} \mathrm{F}\left(705^{\circ} \mathrm{C}\right)$ inlet temperature, 79.2 psia ( $0.5 \mathrm{MPa})$ inlet pressure, 15.64 psia (0.1 MPa) exhaust pressure, $288,000 \mathrm{lb} / \mathrm{hr}(36 \mathrm{~kg} / \mathrm{sec})$ flow]

\begin{tabular}{|c|c|c|c|c|c|c|c|}
\hline & \multirow[b]{2}{*}{ Stage } & \multicolumn{2}{|c|}{ Blade root } & \multicolumn{2}{|c|}{ Blade midsection } & \multicolumn{2}{|c|}{ Blade tip } \\
\hline & & $\begin{array}{l}\text { Volocity } \\
\text { (fps) }\end{array}$ & $\begin{array}{l}\text { Distance } \\
\text { from conter } \\
\text { of rulur } \\
\text { (in.) }\end{array}$ & $\begin{array}{c}\text { Velocity } \\
\text { (fps) }\end{array}$ & $\begin{array}{l}\text { D1stance } \\
\text { from senter } \\
\text { UI lulul } \\
\text { (in.) }\end{array}$ & $\begin{array}{c}\text { Velonsity } \\
(f \mu s)\end{array}$ & $\begin{array}{c}\text { Distance } \\
\text { frnm renter } \\
\text { uf lulul } \\
\text { (in.) }\end{array}$ \\
\hline 1 . & $\begin{array}{l}\text { Stator inlet } \\
\text { Stator exit } \\
\text { Rotor inlet } \\
\text { Rotor exir }\end{array}$ & $\begin{array}{r}1314 \\
840 \\
833\end{array}$ & $\begin{array}{l}10.3 \\
10.3 \\
10.3\end{array}$ & $\begin{array}{r}1125 \\
599 \\
889\end{array}$ & $\begin{array}{l}12.25 \\
12.25 \\
12.25\end{array}$ & $\begin{array}{l}990 \\
450 \\
952\end{array}$ & $\begin{array}{l}14.25 \\
14.25 \\
14.25\end{array}$ \\
\hline 2. & $\begin{array}{l}\text { Stator inlet } \\
\text { Stator exit } \\
\text { Rotor inlet } \\
\text { Rotur exit }\end{array}$ & $\begin{array}{r}456 \\
1296 \\
825 \\
854\end{array}$ & $\begin{array}{l}10.3 \\
10.3 \\
10.3 \\
10.3\end{array}$ & $\begin{array}{r}440 \\
1085 \\
558 \\
919\end{array}$ & $\begin{array}{l}12.25 \\
12.60 \\
12.60 \\
12.60\end{array}$ & $\begin{array}{l}43 n \\
941 \\
424 \\
995\end{array}$ & $\begin{array}{l}14.25 \\
1.4 .95 \\
14.95 \\
14.95\end{array}$ \\
\hline 3. & $\begin{array}{l}\text { Stator inlet } \\
\text { Stator exit } \\
\text { Rotor inlot } \\
\text { Rotor exit }\end{array}$ & $\begin{array}{r}473 \\
1265 \\
798 \\
896\end{array}$ & $\begin{array}{l}10.3 \\
10.3 \\
10.3 \\
10.3\end{array}$ & $\begin{array}{r}453 \\
1030 \\
512 \\
996\end{array}$ & $\begin{array}{l}12.60 \\
13.05 \\
13.05 \\
13.05\end{array}$ & $\begin{array}{r}441 \\
884 \\
421 \\
1057\end{array}$ & $\begin{array}{l}14.95 \\
15.80 \\
15.80 \\
15.80\end{array}$ \\
\hline 4. & $\begin{array}{l}\text { Stator inlet } \\
\text { Stator exit } \\
\text { Rotor inlet } \\
\text { Rotor exit }\end{array}$ & $\begin{array}{r}510 \\
1265 \\
802 \\
918\end{array}$ & $\begin{array}{l}10.3 \\
10.3 \\
10.3 \\
10.3\end{array}$ & $\begin{array}{r}486 \\
1005 \\
499 \\
998\end{array}$ & $\begin{array}{l}13.05 \\
13.55 \\
13.55 \\
13.55\end{array}$ & $\begin{array}{r}466 \\
849 \\
457 \\
1106\end{array}$ & $\begin{array}{l}15.80 \\
16.80 \\
16.80 \\
16.80\end{array}$ \\
\hline 5. & $\begin{array}{l}\text { Stator inlet } \\
\text { Stator exit } \\
\text { Rotor inlet } \\
\text { Rotor exit }\end{array}$ & $\begin{array}{r}538 \\
1245 \\
783 \\
940\end{array}$ & $\begin{array}{l}10.3 \\
10.3 \\
10.3 \\
10.3\end{array}$ & $\begin{array}{r}505 \\
948 \\
457 \\
1040\end{array}$ & $\begin{array}{l}13.55 \\
14.30 \\
14.30 \\
14.30\end{array}$ & $\begin{array}{r}489 \\
789 \\
504 \\
1176\end{array}$ & $\begin{array}{l}16.80 \\
18.25 \\
18.25 \\
18.25\end{array}$ \\
\hline
\end{tabular}


The turbine was operated $1963 \mathrm{hr}$ cumulative in two tests with an inlet temperature of approximately $1230^{\circ} \mathrm{F}\left(666^{\circ} \mathrm{C}\right)$. The first test ran for $878 \mathrm{hr}$ and was ended by buildup of deposits on the first-stage stator blading. The buildup caused surging in the compressor which prevented restart after a shutdown. The turbine was disassembled, inspected, cleaned, and returned to service. The second test of the turbine continued for $1085 \mathrm{hr}$ and shutdown was voluntary for evaluation of the erosion damage to the blading.

A description of the condition of the turbine blading after the two tests is excerpted from Ref. 31 .

The first-stage stator blades showed little visible evidence of erosion. Blades in stages 2 to 5 were significantly eroded at the outer sidewall bases. Except for the first stage, ash deposition on the blades was minimal. Pressure faces of the first-stage stators were relatively clean, but their backs were coated with ash. Also, large curlicues of hard, bonded ash gradually built up between the bases of the first-stage stator blades, eventually blocking the gas flow and forcing an end to the test. Light deposits of ash formed on the second-stage stators, and they were slightly eroded as indicated by a polished area at the base of the leading edge.

Only very light deposits of ash formed on the last three stages of stator blades. Ash eroded notches in the polished areas at the base of the leading edges of these blades, just above the titanium carbide inserts, and thinned the edges of these blades near the bases.

The rotor blades were in excellent condition fullowing the first test. Although not seriously eroded, polished spots on the leading edges and sides of the base of rotor blades in rows 3,4 , and 5 indicated minor erosion caused by concentration of ash near the rotor. The rotor blades were lightly coated with ash, primarily on the backs; the coating was heaviest on the first stage and progressively lighter on successive stages.

Inspection after the second test indicated that the ash deposition and erosion followed the same pattern as in the first test, although the ash buildup on the first-stage blades was not as heavy as before. The stator blades were eroded in the same areas as in the first test, but erosion was more severe. Much larger notches were cut into the bases of the leading edges, primarily in rows 2,3 , and 4 . Also, ash eroded the trailing edges of the blades in these rows much more than in the first test.

The rotor blades after the second test showed little damage, with the extent and pattern of ash deposition approximately 
the same as after the first test. The rotor blades were visibly free of wear after the second test, although slight wear was visible along $1 / 3$ the length of the leading edge of each blade, measured from the tip. All rotor blades were weighed before and after the second test. The weight loss for each blade was almost constant at 9 grams. All in all, the rotor blades were in good condition following the second test, and without notches at the roots of the blades - the most seriously eroded area in the 1ast LDC test.

The significant increase in stator blade erosion in the second test was unexpected because both operating conditions and running time were virtually the same as in the first test. This marked increase in erosion is attributed to false information from improperly connected thermocouple leads. Thermocouple readings served to indicate ash plugging of the discharge lines of the centrifugal-type ash separators - 26 in two banks of 13 tubes each. Thermocouple leads from each bank were connected to separate recorders. For the first 185 hours of the second test, these leads were connected to opposite banks, plugging of separators in the right bank being indicated on the left bank recorder. The thermocouples were believed faulty when plugging was not verified by examination; therefore, operations were carried on with several plugged separators in one bank. Thus, the concentration and size of ash entering the turbine probably was markedly higher during the first 185 hours of the second test.

Rotor blade profiles, measured with a probograph before and after each test to determine the loss of metal from erosion, indicated the rotor suffered comparible wear. Similar measurements could not be made on the stator blades, because they were welded together into segments. These measurements showed that 70 percent of the wear on the pressure faces of the rotor blades occurred during the 1085-hour second test. Thus, the average erosion rate during the second test was almost twice that of the first test.

Blade erosion was effectively reduced by the blade design. Aerodynamic features of the new blades reduced the concentration of $a s h$ at the rotor - the rotor blade roots and stator blade tips were not seriously eroded. Small quantities of ash, however, st111 concentrated near the rotor, as evidenced by shiny areas at the bases of the rotor blades in the last three rows. Also, as expected, ash concentrated heavily at the turbine casing, eroding the rotor blade tips and stator blade bases.

Effectiveness of another design feature, the stepped-sidewalls and titanium carbide wear strips, is questionable. Erosion of stator blade roots was not prevented, and it is not clear if the reduced erosion of the rotor blade roots was due to the wear strips or the aerodynamic design features intended to concentrate ash at the casing. None of the wear strips were significantly eroded. Significant quantities of ash may have struck the rotor 
blade wear st.rips, but with insufficient velocity to erode the titanium carbide.

Manufacturers of industrial gas turbines (who inspected the blades) and Bureau of Mines engineers estimate the effective life of the rotor blades as $20,000 \mathrm{hr}$ and the stator blades at 5,000 $\mathrm{hr}$. These estimates assume a uniform erosion rate, and are based on the condition of the blades after $1963 \mathrm{hr}$. If these figures are adjusted to compensate for the plugged ash separator discharge lines in the second test, the estimated life for the rotor blades would be $30,000 \mathrm{hr}$ and for the stator blades $7500 \mathrm{hr}$.

A summary of the operating experience by both the Locomotive Development Committee and the U.S. Bureau of Mines on the five-stage Houdry turbine and six-stage Locomotive turbine is given in l'able A.5. It should be noted that the 757-hr test in 1952 and the 1085-hr test in 19.64 were conducted under conditions of unknown ash separator efficiency at the start of the experiments. For the remaining data given in Table A.5, the flyash separation system was functioning as designed throughout the test. Examination of these data indicate that satisfactory operation (minimal deposits and erosion) for a direct coal-fired gas turbine could be obtained for a particulate loading of approximately $100 \mathrm{ppm}$ with a size range of 10 to $15 \%$ plus $10 \mu \mathrm{m}$ and 1 to $2 \%$ plus $20 \mu \mathrm{m}$ at a turbine inlet temperature of 740 to $1060^{\circ} \mathrm{F}\left(394-571^{\circ} \mathrm{C}\right)$.

\section{Aeronautical Research Laboratories}

Ruston and Hornsby "TA" turbine

During the period between 1948 and 1970, the Aeronautical Research Laboratories (ARL), Department of Supply, Melbourne, Australia, investigated the technical feasibility of the direct-fired operation of a coalburning gas turbine. The following description of their work is excerpted from Ref. 33 .

In the earlier stages of the investigation (1948-1958), rig scale experiments were conducted on three aspects of the generai problem:

a. coal pulverizing and handling,

b. high intensity combustion and combustor development,

c. ash fouling and erosion. 
Table A.5. Locomotive Dejelopment Committee oferating experience with open-cycle ccal-jurning gas turbines

\begin{tabular}{|c|c|c|c|c|c|c|c|c|c|c|}
\hline Engine ${ }^{a}$ & $\begin{array}{l}\text { Year of } \\
\text { test }\end{array}$ & $\begin{array}{c}\text { Power } \\
{[k W(e)]}\end{array}$ & $\begin{array}{c}\text { Turbire inlet } \\
\text { temperature } \\
\left({ }^{\circ} \mathrm{F}\right)\end{array}$ & $\begin{array}{l}\text { Air flow } \\
\text { (1b, sec) }\end{array}$ & $\begin{array}{l}\text { Tip speec } \\
\text { (fF:s) }\end{array}$ & $\begin{array}{l}\text { Maximum length } \\
\text { of run } b \\
\text { (hr) }\end{array}$ & $\begin{array}{l}\text { Total running } \\
\text { time } \\
\text { (hr) }\end{array}$ & $\begin{array}{l}\text { Particulate } \\
\text { content } \\
(\mathrm{ppm})\end{array}$ & $\begin{array}{l}\text { Particle } \\
\text { size } \\
(\%+10 \mu / \\
\%+20 \mu)\end{array}$ & $\begin{array}{l}\text { Erosion } \\
\quad \text { and } \\
\text { deposits }\end{array}$ \\
\hline \multicolumn{11}{|c|}{ Negligible erosion and deposits } \\
\hline A & 1951 & 0 & 740 & 97 & & 250 & 1250 & 88 & $16 / 2.1$ & $\mathrm{E}-\mathrm{N}, \mathrm{D}-\mathrm{S}$ \\
\hline B & 1951 & 1500 & $1 C 60$ & 97 & 713 & 178 & 178 & & $15 / 1.5$ & E-N, D-N \\
\hline B & 1954 & 1500 & $1 C 60$ & 97 & 713 & 300 & 300 & $\sim 130$ & $10 / 1$ & $\mathrm{E}-\mathrm{N}, \mathrm{D}-\mathrm{N}$ \\
\hline \multicolumn{11}{|c|}{ Serious erosion and deposits } \\
\hline A & 1950 & 0 & 740 & 9.7 & & 250 & 1250 & & $42 / 8$ & E-H, D-N \\
\hline $\mathrm{A}$ & 1950 & 0 & 740 & 97 & & 250 & 1250 & & $31 / 5$ & $\mathrm{E}-\mathrm{H}, \quad[-\mathrm{N}$ \\
\hline A & 1951 & 0 & 740 & 5 & & $250_{d}$ & 1250 & & $59 / 22$ & $E-M,[-N$ \\
\hline B & 1952 & 2060 & 1225 & 6.6 & $8 \cong 2$ & $757^{d}$ & 757 & $170^{e}$ & $15 / 2^{e}$ & $\mathrm{E}-\mathrm{H}, \mathrm{C}-\mathrm{N}$ \\
\hline B & 1955 & $2-50$ & 1250 & 6.6 & $8 \lesssim 2$ & $12 ? 1$ & 1421 & & $32 / 12$ & $E-M,[-S$ \\
\hline B & 1957 & 2210 & 1250 & $6-6$ & $8 \equiv 2$ & $1102 f$ & 1103 & & $32 / 12$ & $E-M, \quad D-S$ \\
\hline C & 1963 & 1235 & 1229 & 6.6 & $8 \Xi 2$ & $878^{f}$ & 878 & 210 & $10 / 2$ & E-M, [-H \\
\hline $\mathrm{C}$ & 1964 & 1235 & 1229 & 6.6 & $8 \leftleftarrows 2$ & 1085 & 1085 & $210^{9}$ & $10 / 2^{g}$ & $E-M, \quad[-M$ \\
\hline
\end{tabular}

${ }^{a}$, Allis-Chalmers 5-saga Houdry tu=bine; B, AlE İs-Chalmers 6-stage locomotive turbine; C, Ailis-chalmers 5-stage turbine (turbine $B$ modified and operated sy the U.j. Burean of Mines).

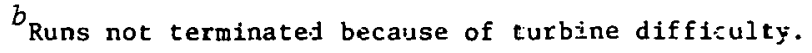

CDeposits: D-N, nezligible; D-S, slight; D-M, moderate; [-H, heavy. Erosion: E-N, negligible; E=S, slight; E-M, moderate; E-H, heavy.

$d_{\text {Run terminated because of najor reduction in output power. }}$

${ }^{e}$ Separator inoperative first $71 \mathrm{hr}$ and detericration throighout test.

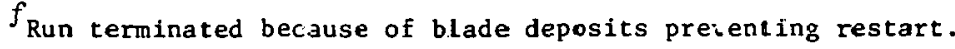

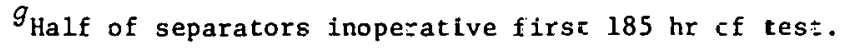


By mid-1953 the research program had reached the stage where it was'believed that most of the difficulties to be encountered with fuel preparation and combustion had been revealed.

The results of tests on a coal-fired rig turbine based on an aircraft supercharger produced little evidence of erosion but revealed a serious ash deposition problem. The real magnitude of the ash deposition problem was not known, because the rig turbine blading was aerodynamically crude as compared to the current gas turbine technology; and it was believed that the rate of ash deposition rould be a strong function of the blade configuration.

A Ruston and Hornsby "TA" gas turbine system was obtained and commissioned in 1958. The system consisted of a 13-stage axial compressor driven by a 2-stage turbine. The gas exhaust from the compressor drive turbine was used to drive a 2-stage power turbine. The engine was designed for operation on distillate fuel with a maximum turbine inlet temperature of $1340^{\circ} \mathrm{F}$ $\left(727^{\circ} \mathrm{C}\right)$. For operation with direct coal firing, the maximum turbine inlet temperature was reduced to $1202^{\circ} \mathrm{F}\left(650^{\circ} \mathrm{C}\right)$.

Comparative operating data on oil and coal are listed in Table A.6. For the initial testing machine, the fuel oil combustor was replaced with a close-coupled coal-burning combustion chamber using Yalbourn brown

Table A.6. Operating data for Ruston and Hornsby turbine fueled with oil and coal

\begin{tabular}{lll}
\hline & \multicolumn{1}{c}{$\begin{array}{c}\text { Oil } \\
\text { operation }\end{array}$} & $\begin{array}{c}\text { Coal } \\
\text { operation }\end{array}$ \\
\hline $\begin{array}{l}\text { Compressor turbine inlet temperature, } \\
\text { max }{ }^{\circ} \mathrm{F}\left({ }^{\circ} \mathrm{C}\right)\end{array}$ & $1,340(727)$ & $1,202(650)$ \\
Power output, bhp (kW) & $1,300(970)$ & $900(671)$ \\
Air flow, lb/sec (kg/sec) & $23(10.46)$ & $20(9.09)$ \\
Compressor pressure ratio & 4.15 & 3.33 \\
Compressor speed, rpm & 11,500 & 10,200 \\
Power turbine inlet temperature, ${ }^{\circ} \mathrm{F}\left({ }^{\circ} \mathrm{C}\right)$ & $1,024(551)$ & $946(507)$ \\
Puwer turbine exhaust temperature, ${ }^{\circ} \mathrm{F},\left({ }^{\circ} \mathrm{C}\right)$ & $844(451)$ & $800(427)$ \\
Power turbine speed, rpm & 6,000 & 5,000 \\
First-stage stator mean exit velocity & $1,265(386)$ & $1,100(335)$ \\
$\quad$ Compressor turbine, fps (m/sec) & $902(275)$ & $784(239)$ \\
$\quad$ Power turbine, fps (m/sec) & & \\
\hline
\end{tabular}


coal as the fuel. Typically this coal contains $15 \%$ moisture, $1.5 \%$ ash, and $44 \%$ volatile matter and has a higher heating value of $9290 \mathrm{Btu} / \mathrm{bb}$ $\left(2.16 \times 10^{7} \mathrm{~J} / \mathrm{kg}\right)$.

The ash from the combustion of the coal fuel was fed directly to the compressor turbine with the combustion air without any attempts to reduce the ash content by means of an ash separator.

During the preliminary tests with solid fuel, low combustion efficiency and large coal particle sizes (30 to $40 \%$ greater than $53 \mu \mathrm{m}$ ) resulted in high blade erosion rates and heavy sintered deposits on the convex surface of all blade rows in the compressor turbine.

Modifications to the coal pulverizer produced. a coal feed $80 \%$ smaller than $53 \mu \mathrm{m}$. The system was operated at a compressor turbine inlet temperature of $1202^{\circ} \mathrm{F}\left(650^{\circ} \mathrm{C}\right)$ for a period of $20 \mathrm{hr}$.

The turbine was operated with distillate fuel for short periods during the test to obtain a measure of the engine performance. These tests showed a decrease in the power output of $2.5 \%$ over the $20-\mathrm{hr}$ period. Inspection after the 20-hr test showed a severe buildup of ash on the stator leading edge which probably resulted in a reduction in the "swallowing" capacity of the engine.

Erosion of the stator and rocor blades occurred in both slayes of the compressor and the power turbine. The metal loss rates for the stator blading are given in Table A.7. The erosion rates are based upon the blade wetted area.

Table A.7. Stator blade weight loss - 20-hr test without ash separation (Réf. 33)

\begin{tabular}{llll}
\hline & \multicolumn{2}{c}{ Erosion } & rate $(\mathrm{mg} / \mathrm{cm} / \mathrm{hr})$ \\
\cline { 2 - 4 } & Maximum & Minimum & Average \\
\hline Compressor turbine & & & \\
First row & 1.2 & 0.34 & 0.62 \\
Second & 2.73 & 1.34 & 2.15 \\
Power turbine & & & \\
First row & 0.16 & 0.09 & 0.13 \\
Second row & 0.21 & 0.16 & 0.20 \\
\hline
\end{tabular}


The following description of the ash deposition is taken from Ref. 33:

The magnitude of the ash deposition problem was indicated in the tests. The blades most seriously affected were in the first stator row of the compressor turbine which received gases from the combustor at the highest temperature, and at the relatively low velocity of $540 \mathrm{fps}(165 \mathrm{~m} / \mathrm{s})$. Two types of ash deposit were evident:

(a) A dense, sintered material in the region of the leading edge of the blade, and, depending on the position of the blade in the stator ring, extending over a portion of the concave or convex face. It appeared to build up in the areas of attached flow, was very brittle and often spalled away from the blade on cooling; polishing of the blade surface increased the tendency for the deposit to break away.

(b) A light brown, powdery deposit, which built up to a depth of about $1 / 16$ in. (1.6 mm) downstream of a region of flow separation, mainly. on the convex surface. Particles from this deposit were in the submicron range and could be easily removed from the blade surface by water washing.

The dense, sintered deposit was confined to the first row of stator blades; the remaining rows of stators, and the rotor blades in the compressor and power turbines, exhibited a light powdery deposit only in regions of separated flow.

Examination of the hard deposit under a microscope revealed a porous matrix, but it was not possible to identify individual particles. An X-ray diffraction analysis showed that the principal constituent was magnesium oxtde, together with iron oxide and calcium sulphate. A chemical analysis confirmed these findings and indicated also the presence of small smounts of sodium, presumably in the form of sodium sulphate. The relative concentrations of the constituents of the deposit were similar to those existing in the original coal ash.

These tests showed that blade erosion would be a serious problem. With the existing engine arrangement the high rate of metal removal, particularly in the second stage of the compressor turbine, would not be industrially acceptable; it was estimated that the life of the more heavily eroded blades would be of the order of $100 \mathrm{hr}$.

The operation of the engine was satisfactory, although the power output at the turbine inlet temperature of $650^{\circ} \mathrm{C}\left(1,202^{\circ} \mathrm{F}\right)$ decreased by the order of 2.5 percent over the 20 -hour period. The progressive deposition of the hard ash on the concave face of the first row of stator blades would constitute an obstacle to extended running even if blade erosion could be prevented. 
Early bench-scale ash deposition experiments conducted by ARL indicated the importance of the effects of incomplete combustion of the fuel upon the formation of deposits. ${ }^{33}$. One of these experiments involved the impingement of ash-char and ash-coal mixtures on a flat specimen placed $5 / 8 \mathrm{in.}(1.59 \mathrm{~cm})$ from and at $90 \mathrm{deg}$ to the supply nozzle. A description of the results of this experiment is taken from Ref. 33:

Impingement tests were made with compositions containing 25, 50,75 and 100 percent of coal or char, the remainder being ash, prepared by burning a representative sample of coal and then grinding it tó less than $10 \mathrm{\mu}$ ill size.

The ratio of coal or char to ash in the mixture at the instant of impingement differs from that of the original mixture introduced into the airline; some of the coal or char particles burn in passing through the heating coll thus reducing the effective ratio of carbon to ash.

No trace of unburnt carbon was detected in the deposit. It would seem that any carbon particles which reached and adhered to the specimen were burned in the presence of excess oxygen. However, the addition of coal or char to the ash could increase the weight of the deposit by as much as ten times.

The maximum weight of deposit occurred with concentrations of coal or char in the mixture of between 25 and 50 percent. In general, the weight of deposit was greater with coal than with char, particularly for the larger particle sizes.

Figure A.11 shows the weight of deposit expressed as a percentage of the total ash fed into the system. The total ash fed is the sum of the ash constituent plus the ash content of the coal or char. Therefore as the proportion of coal or char in the mixture increases, the total weight of ash fed in a given time decreases.

It was significant that the percentage build-up was generaliy greater for the coarse particle sizes of boch coul dnd cluai, and increased as the percentage of carbon in the mixture increased. This may be explained by the burning of the coal or char particles within the furnace. This action would release ash at temperatures closer to the combustion temperature of coal or char than the ambient temperature of the carrying air. Cercain conetituents would probably be quite sticky and able to form a coherent structure in which the more refractory particles could be retained upon impingement.

The results of this experiment clearly indicate the importance of complete combustion of the carbon ahead of the turbine upon the formation of deposits in a coal-fired gas turbine. 

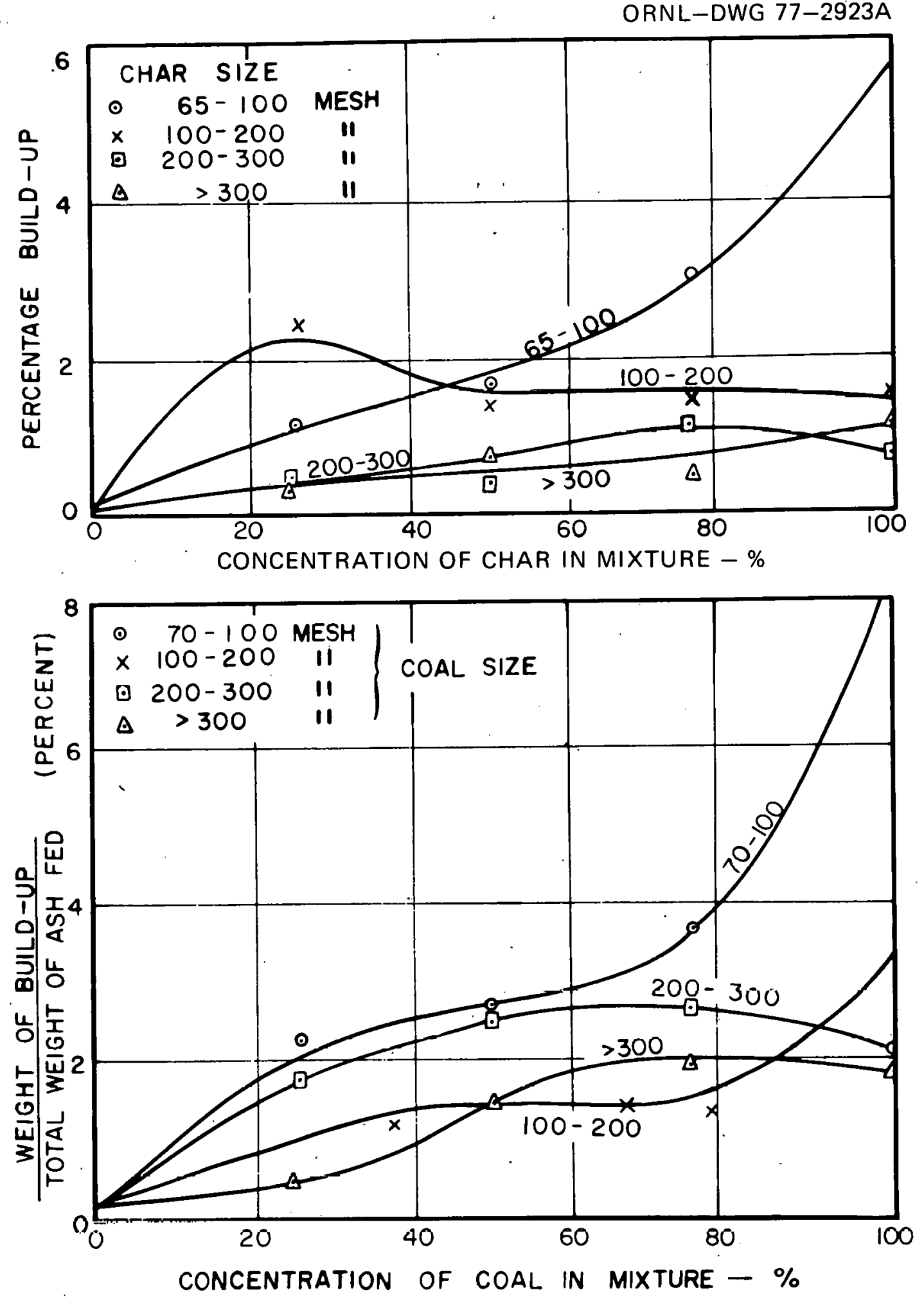

Fig. A.11. Deposition of ash-coal and ash-char mixtures (Ref. 33). 
The effects of gas velocity and temperature upon the deposition rate of flyash produced by coal combustion without ash separation were investigated by ARL. ${ }^{3}$ Two experiments were conducted: one measured the effects of temperature at a constant velocity of $350 \mathrm{fps}(107 \mathrm{~m} / \mathrm{s})$, and the second measured the effects of velocity at a constant temperature of $1290^{\circ} \mathrm{F}$ $\left(700^{\circ} \mathrm{C}\right)$. Two distinct types of deposit were observed: a dense sintered deposit formed in the region of direct impingement and a light soft deposit in the region of separated flow. Both of these experiments were conducted with a close-coupled combustor that allowed incandescent particles (determined by visual observation) to strike the target.

An erosion experiment conducted by Fisher and Davis ${ }^{10}$ with raw flyash obtained from several power plants operating on pulverized coal resulted in both dense and light soft deposits similar to those described in the ARL work.

A carpet plot employing these data is shown in Fig. A.12. The extrapolation of the data in the figure indicates the interrelationship of the gas temperature and velocity on the ash deposition. The deposition varies directly with the fifth to seventh power of the absolute gas temperature and inversely as the first power of the gas velocity.

Another experiment was conducted by $\mathrm{ARL}^{33}$ to determine the effect of combustion residence time upon the ash deposition. A target was placed $20 \mathrm{ft}(6.1 \mathrm{~m})$ from the exit of the combustor. At an operating temperature of $1292^{\circ} \mathrm{F}\left(700^{\circ} \mathrm{C}\right)$, a. threefold reduction in dense deposit was measured as compared to a target placed at the combustor exit.

These experiments indicate the importance of complete combustion in avoiding deposits of ash in the turbine system. It was considered that deposition could be reduced by one of three methods. A description of the methods is taken from Ref. 33:

(a) removal of the larger particles prior to entering the combustor;

(b) increasing the residence time in the combustor to ensure complete burnout;

(c) removal of the larger particles after combustion but prior to entering the turbine.

Based on the experience gained in combustor development, it was considered that unless fine grinding combined with classification ensured 100 percent rejection of coal particles greater 
ORNL-DWG 76-20531A

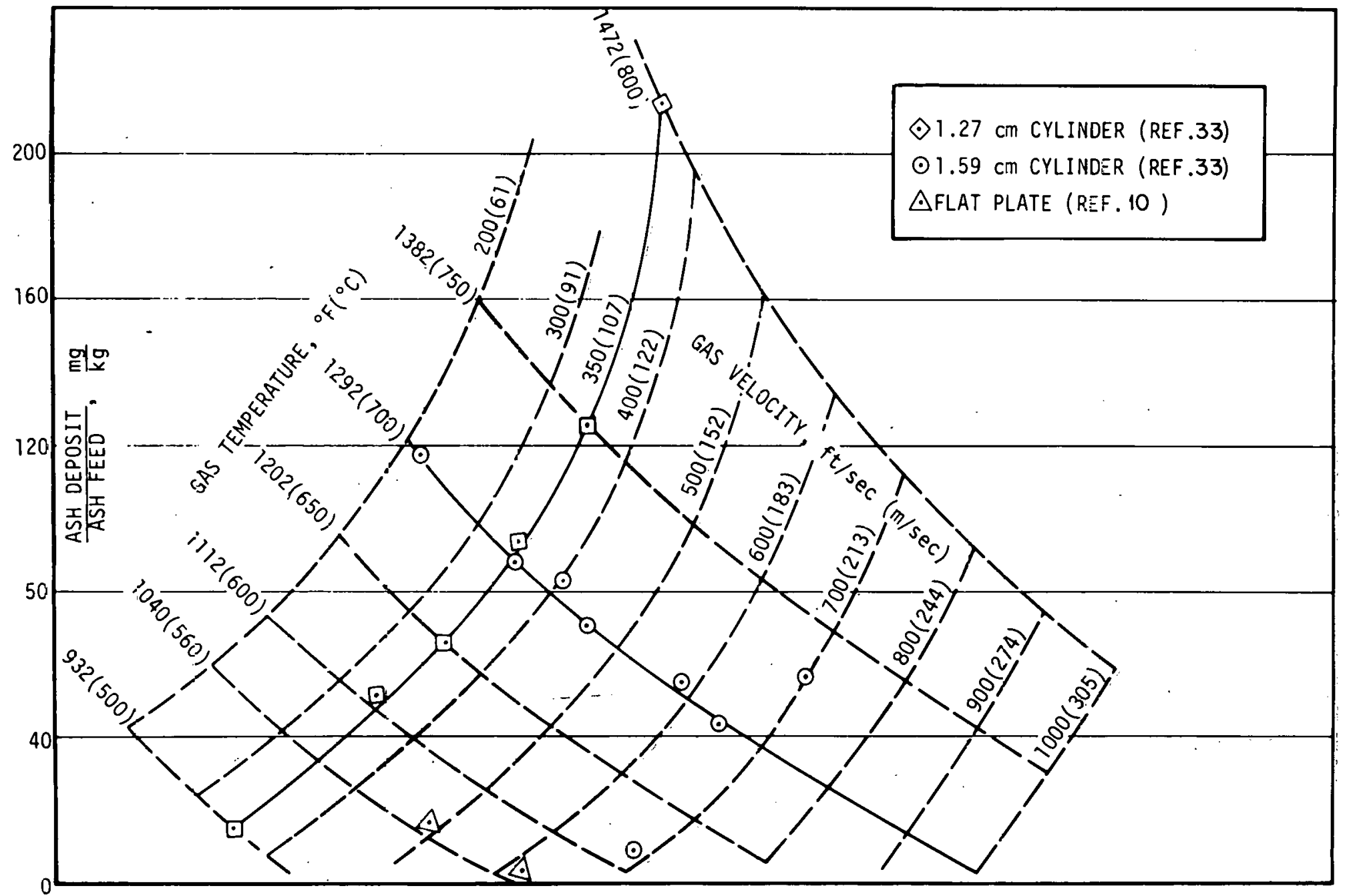

Fig. A.12. Effects of temperature and velocity on ash deposition. 
than 300 B.S.S. sieve size $(53 \mu)$, the benefits from this source alone would be marginal. Apart from this, the cost of grinding and classifying to this standard would be prohibitive.

A substantial increase in the residence time in the combustor and the turbine inlet appeared to be the most reliable arrangement. The elimination of the larger particles from the gas stream would be expected to reduce both the rate of deposition and the rate of erosion.

The experimental arrangement was modified to include a multicyclone ash separator consisting of 48 cyclone separators of 6 in. $(15.2 \mathrm{~cm})$ diameter. The coal combustor was close-coupled to the ash separator and the clean gas fed to the compressor turbine through approximately $40 \mathrm{ft}$ $(12.2 \mathrm{~m})$ of $18-i n .(45.7-\mathrm{cm})$ pipe. The increased separation of the coal combustor from the turbine inlet should provide additional time for afterburning and result in lower unburned fuel fed to the turbine.

Table A. 8 gives the compositions of the blade material used in the tests of the Ruston and Hornsby "TA" gas turbine. All the blading used in the 20-hr test without an ash separator was Nimonic $89 \mathrm{~A}$ except for the compressor turbine first-stage rotor where Nimonic 90 was used.

Prior to a 20-hr test of the system with an ash separator, samples of stator blades fabricated from C.242 and H.R. Crown Max. alloys (see Table A.8) were fitted to the two stator rows of the compressor turbine. Several of the C. 242 blades were given a sprayed alumina surface coating.

During the 20-hr test with the ash separator, the compressor turbine inlet temperature was maintained at $1202^{\circ} \mathrm{F}\left(650^{\circ} \mathrm{C}\right)$. Material (ash plus carbon) entered the separator from the combustor at a rate of $71.251 \mathrm{~b} / \mathrm{hr}$ $(32.4 \mathrm{~kg} / \mathrm{hr})$. This material contained approximately $50.9 \%$ carbon. Material (virtually pure ash) left the separator and entered the compressor turbine at a rate of $21.75 \mathrm{lb} / \mathrm{hr}(9.9 \mathrm{~kg} / \mathrm{hr})$ at a particulate concentration of $340 \mathrm{ppm}$ and particle size range of $3.8 \%$ plus $20 \mathrm{p} / \mathrm{m}$ and $26 \%$ plus $10 \mathrm{\mu m}$. The following description of the ash deposition and blade erosion during the 20-hr test with ash separation is taken from Ref. 33:

Examination of the turbine b.lades after the 20-hour test showed that removal of certain ash constituents by the ash separator had markedly changed the balance between ash erosion and deposition. 
Table A.8. Blade composition (Ref. 33)

\begin{tabular}{|c|c|c|c|c|c|c|c|c|c|c|c|c|}
\hline \multirow{2}{*}{ Blade material } & \multicolumn{12}{|c|}{$\begin{array}{c}\text { Composition } \\
(\%)\end{array}$} \\
\hline & C & $\mathrm{Si}$ & $\mathrm{Fe}$ & Mn & ${ }^{\circ} \mathrm{Cr}$ & $\mathrm{T} \mathbf{i}$ & Al & Co & Mo & $\mathrm{Ni}$ & 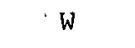 & $\mathrm{Cb}$ \\
\hline $\begin{array}{l}\text { Nimonic } 90 \\
\text { Nimonic } 80 \mathrm{~A} \\
\text { Haynes stellite H.S. } 31 \\
\text { N. } 155 \\
\text { C. } 242 \\
\text { H. R. Crown Max. }\end{array}$ & $\begin{array}{l}0.13 \\
0.10 \\
0.45-0.6 \\
0.2-0.4 \\
0.27-0.35 \\
0.15-0.25\end{array}$ & $\begin{array}{l}1.5 \\
1.0 \\
0.5 \\
0.2-0.5 \\
0.75-2.0\end{array}$ & $\begin{array}{l}5.0 \\
5.0 \\
2.0 \\
30.0 \\
0.75 \\
\mathrm{Ba} 1\end{array}$ & $\begin{array}{l}1.0 \\
1.0 \\
1.5 \\
0.2-0.5 \\
0.01 \\
\operatorname{Max} .\end{array}$ & $\begin{array}{l}18-21 \\
18-21 \\
23-28 \\
21 \\
20-23 \\
20-25\end{array}$ & $\begin{array}{l}1.8-3.0 \\
1.8-2.7\end{array}$ & $\begin{array}{l}0.8-2.0 \\
0.5-1.8\end{array}$ & $\begin{array}{l}15-21 \\
2.0 \\
\mathrm{Ba} 1 \\
20 \\
9.5-11\end{array}$ & $\begin{array}{l}3 \\
10-11\end{array}$ & $\begin{array}{l}\text { Bal. } \\
\text { Bal. } \\
9-12 \\
20 \\
\text { Bal. } \\
10-15\end{array}$ & $\begin{array}{l}6-9 \\
2.5 \\
2.5-3.5\end{array}$ & 1.0 \\
\hline
\end{tabular}


The hard sintered deposit found on the first row stator blades in the test without the separator was no longer in evidence, and had been replaced by a lightly bonded material; althrough the total weight of deposit on the blade had been reduced, the area of blade covered by ash had increased. The material on the leading edge was generally friable, but showed no tendency to spall away from the blade, even under conditions of rapid heating and quenching.

The distribution of ash between the compressor turbine stator rows varied from that in the earlier test; the deposit on the second row stators was now much greater than on the first row, but the material was of similar density. The first and second stage rotor blades now cariied a deposit on their leading edges whereas formerly the metal had been eroded in this position; on all blades there was a light fluffy deposit in regions of separated flow. Table A.y gives a comparison of the ash deposition rates on the blade rows in the two tests.

With the increase in the area of the blades covered by the ash deposit, the areas of erosion were correspondingly reduced. Impact-type erosion on the leading edge of the second row stators and the first stage rotors of the compressor turbine, and undercutting of the leading edge of both rotor stages at the blade root, were eliminated and replaced by ash deposition. Similarly,

Table A.9. Variation in deposit rate in

$20 \mathrm{hr}$ running - turbine inlet gas temperature $650^{\circ} \mathrm{C}\left(1202^{\circ} \mathrm{F}\right)$

(Ref. 33)

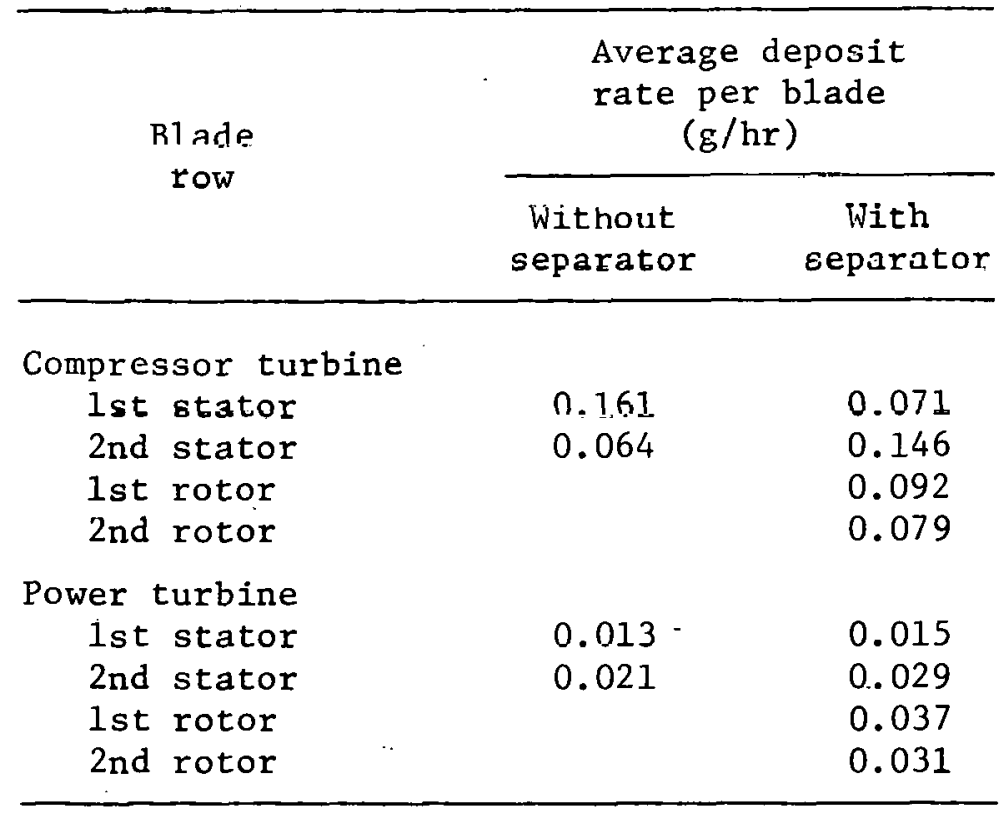


the leading edges of the power turbine stators were no longer polished but had acquired a thin film of ash.

Removal of metal from all stator and rotor blade stages was now confined to a scouring process over the trailing half of the pressure (concave) face of the blade.

Table A.10 gives the measured weight loss for the original Nimonic-80A blades over the 20-hour test period with and without gas cleaning. Weight losses are expressed on the basis of unit blade wetted area.

With the inclusion of the ash separator, the rate of metal loss in the compressor turbine had been reduced by factors of 30 and 70 respectively in the successive stator stages; these factors are based on the average value over the blade row. The wear rate between individual blades in a row varied by a factor of 4 and 3 in the first two stator rows respectively, and 1.5 in the later stages due to the asymmetric ash concentration caused by the inlet duct. Owing to the relative difficulty of removing rotor blades for cleaning and weighing, only one blade in each rotor row was processed and the weight loss was much the same as that of the adjacent stators. (Table A.10).

In view of the elimination of impact erosion on the blade in the tests with ash separation, it is of interest, when correlating changes in metal loss rates with variation in ash quality, to modify the stator stage metal loss factors quoted above to indicate specifically the variation in the rate of trailing edge erosion caused by removal of ash from the working gas. It was

Table A.10. Turbine blade weight loss with Nimonic-80A blades -20 -hr tests (Ref. 33)

\begin{tabular}{lcc}
\hline & \multicolumn{1}{c}{$\begin{array}{c}\text { Erosion rate, av } \\
\left(\mathrm{mg} / \mathrm{cm}^{2}-\mathrm{hr}\right)\end{array}$} \\
\cline { 2 - 3 } & $\begin{array}{c}\text { Without } \\
\text { separator }\end{array}$ & $\begin{array}{c}\text { With } \\
\text { separator }\end{array}$ \\
\hline $\begin{array}{l}\text { High-pressure turbine } \\
\text { 1st stator }\end{array}$ & 0.62 & 0.020 \\
2nd stator & 2.15 & 0.030 \\
1st rotor & & 0.047 \\
2nd rotor & & 0.035 \\
Low-pressure turbine & & 0.006 \\
1st stator & 0.13 & 0.007 \\
2nd stator & 0.20 & \\
1st rotor & & \\
2nd rotor & & \\
\hline
\end{tabular}


computed from blade profile measurements in the test without the ash separator that the ratio of impact erosion metal loss on the leading edge to scouring loss at the trailing edge was 2:5 for the second stage stators. It may therefore be assessed that the trailing edge metal loss alone for this stage was reduced by a factor of 50 by gas cleaning. This process was not applicable to the first stage stators where impact erosion did not take place in the first test, so that in the second test erosion on the concave face was reduced by the full factor of 30 quoted above.

The absolute rate of metal loss from the power turbine was about half that in the compressor turbine, but, because of the larger size of the low pressure blading the metal loss rate basen on the unit area of blade surface was about one quarter.

The wear performance of blades of alternative materials fitted in the first two stator rows of the compressor turbine is given in Table A.ll.

There was a considerable difference in the metal loss rate between the Nimonic $80 \mathrm{~A}$ blades which had also been used in the prevlous test without gas cleaning, and some new Nimonic blades fitted prior to the twenty-hour test with gas cleaning. The weight loss of the new blades was about 0.4 to 0.5 times that of the original blades in both stages. Visual examination of the new blades showed that the original machining marks were still well defined; there was no obvious corrosion or evidence of the oxide layer having failed. Microscopic examination confirmed these findings and showed no sign of corrosion along grain boundaries or sub-surface alloy depletion.

In the instance of the original blades, however, there was polishing of those areas that had been heavily eroded in the

Table A.11. Variation in metal loss rate for various blade materials having material compositions shown in Table A.8 ( $\operatorname{Re}$. 33)

\begin{tabular}{lcc}
\hline Material. & \multicolumn{1}{c}{$\begin{array}{c}\text { Erosion rate } \\
\left(\mathrm{mg} / \mathrm{cm}^{2}-\mathrm{hr}^{2}\right)\end{array}$} \\
\cline { 2 - 3 } & $\begin{array}{c}\text { First-row } \\
\text { stator blades }\end{array}$ & $\begin{array}{c}\text { Sernnd-row } \\
\text { stator blades }\end{array}$ \\
\hline Nimonic 80A, new & 0.008 & 0.015 \\
Nimonic 80A, o1d & 0.020 & 0.030 \\
C.242 & 0.121 & 0.037 \\
H.R. Crown Max. & 0.037 & 0.026 \\
Alumina-sprayed surface & & 0.027 \\
on C.242 & & \\
\hline
\end{tabular}


test without ash separation, and pitting of the oxide layer and of the blade surface in regions of transition from deposition to erosion.

The continued resistance of the new blades to corrosive action could not be guaranteed, and the actual difference in overall life of a new blade as compared to an old blade may not be as great as the weight loss measured in this short term test would suggest.

The higher rate of weight loss of the C.242 blades in the first row stators was attributed mainly to the failure of the bond between the oxide layer and the parent metal in a particular area of the blade during cleaning after removal from the engine. This area invariably coincided with a region of a thick deposit of soft ash. One of a number of factors influencing the corrosion or oxidation resistance of high nickel, relatively low chromium alloys is the molybdenum content of the alloy. This element is described as an oxidation accelerant for the parent metal, and maximum quantities of the order of 1.0 percent are recommended; C.242 alloy contains 10 percent. As the C.242 stator blades in the second stage did not show a similar high rate of loss, but were in fact comparable to the Nimonic and H.R. Crown Max. blades, the effect of temperature and thickness of ash coverage might also have an influence on the behaviour of the oxide layer.

The H.R. Crown Max. alloy performed well in the second stage stator row; this material lends itself to relatively cheap precision casting, and could be a possible alternative to the more expensive alloys when gas temperatures are suitable.

The alumina-sprayed blades showed a tendency to surface failure, and the metal loss rates quoted in Table A.ll refer only to blades which retained their surface coating.

After the completion of the 20-hr test with the ash separator, a 203hr test was conducted to establish firm figures for the blade metal loss rates. To avoid difficulties due to blockage of turbine passages by.ash deposits, a cleaning procedure was adopted consisting of the injection of 15 gal (68.2 liters) of water in 10-sec bursts through 36 nozzles situated immediately before the stators while concurrently feeding $6 \mathrm{lb}(2.7 \mathrm{~kg})$ of milled apricot stones into the turbine entry duct. The procedure was carried out over a 2-min period once every $10 \mathrm{hr}$ during the 203-hr test.

The following description of the ash deposition and erosion during the 203-hr test is taken from Ref. 33:

With the one exception noted below, the wear patterns of all blades were similar to those described in the 20-hour test with ash separation. 
Some modification of the overall blade metal loss rates might be expected since the cleaning process itself was reputed to result in some surface erosion caused by impingement of water droplets and cleaning solids. On the other hand long term operation might result in formation of an ash layer on blade surfaces which could protect the blade against abrasion.

Table A.12 shows the total blade metal loss rates for the original Nimonic-80A material obtained during the 200-hour test. The overall metal loss has also been divided into the loss attributable to cleaning and that due to abrasion by ash particles. The cleaning weight loss has been estimated from blade weight losses measured after a typical cleaning cycle.

The overall hourly weight loss from the stator stages of the compressor turbine is less than that encountered in the short term test despite the water spray and abrasive solids. In the power turbine, the reduction in specific weight loss is particularly marked.

The only blade row to show an increased rate of metal loss is the first stage rotor of the compressor turbine. The weight loss quoted is based on measurements on one blade only; removal of rotor blades is not a simple matter and it is not desirable to do this for the complete row. The increased rate of metal loss for this blade over the longer test can be ascribed in part to the loss of blade shape. The rotor blades were not replaced prior to this test and having been subjected to abrasion equivalent to more than 2,000 hours of engine service with ash separation, had commenced to lose sections of the very thin trailing edge.

Examination of the blading after the 200-hour test showed a new area of localized erosion on both rotor stages of the compressor turbine. It consisted of a short groove on the convex face near the blade root at about one third of the chord from the leading edge, and was probably due to the change in tip profile of the adjacent stator blade, which had also been eroded by leakage under the stator tip.

Ash deposits had accumulated in the stator blade passages near the inner diameter owing to the incomplete penetration of the cleaning water spray. Examination of the cleaned blades revealed that surface corrosion had taken place under these ash deposits; the extent of corrosion varied considerably between the varluue blade alloys. Táble A.13 shows the inelal luss rales from the three metal surfaces used in the first and second stator stages of the compressor turbine.

The Nimonic-80A alloy blades exhibited clear signs of corrosion, particularly beiseall the ash deposic near the blade tips which built up in the 200-hour test. Scaling of the oxide layer under ash deposits was marked in the case of H.S. 31 alloy blades in the first stage stators, and was similar to the behaviour of the alloy C.242 used in the 20-hour test. 
Table A.12. Turbine blade metal losses during 200-hr test (Nimonic 80A blades only) (Ref. 33)

\begin{tabular}{|c|c|c|c|c|c|c|c|}
\hline & \multicolumn{3}{|c|}{$\begin{array}{l}\text { Weight loss } \\
(\mathrm{g})\end{array}$} & \multicolumn{3}{|c|}{$\begin{array}{r}\text { Erosion rate } \\
\left(\mathrm{mg} / \mathrm{cm}^{2}-\mathrm{hr}\right)\end{array}$} & \multirow{2}{*}{$\begin{array}{c}\text { Erosion rate, } \\
\text { 20-hr test, } \\
\text { abrasion only } \\
\left(\mathrm{mg} / \mathrm{cm}^{2}-\mathrm{hr}\right)\end{array}$} \\
\hline & $\begin{array}{l}\text { Overall } \\
\text { average }\end{array}$ & $\begin{array}{c}\text { Cleaning } \\
\text { (computed) }\end{array}$ & $\begin{array}{c}\text { Abrasion } \\
\text { (by difference) }\end{array}$ & Cleaning & Abrasion & Overall & \\
\hline \multicolumn{8}{|c|}{ Compressor turbine } \\
\hline lst stator & 0.074 & 0.040 & 0.034 & 0.0079 & 0.0067 & 0.0146 & 0.0203 \\
\hline 2nd stator & 0.195 & 0.040 & 0.155 & 0.0051 & 0.0197 & 0.0248 & 0.0307 \\
\hline lst rotor ${ }^{a}$ & 0.313 & 0.040 & 0.273 & 0.0074 & 0.050 & 0.057 & 0.047 \\
\hline 2nd rotor ${ }^{a}$ & 0.243 & 0.040 & 0.203 & 0.0057 & 0.028 & 0.034 & 0.035 \\
\hline \multicolumn{8}{|l|}{ Power turbine } \\
\hline lst stator & 0.008 & & 0.008 & & 0.0006 & 0.0006 & 0.0056 \\
\hline 2nd stator & 0.019 & & 0.019 & & 0.0012 & 0.0012 & 0.0071 \\
\hline lst rotor a & 0.007 & & 0.007 & & 0.0007 & 0.0007 & \\
\hline 2nd rotor & 0.010 & & 0.010 & & 0.0009 & 0.0009 & \\
\hline
\end{tabular}

$a_{\text {Single blades. }}$ 
Table A.13. Comparison of average metal loss rates for different blade materials (Ref. 33)

\begin{tabular}{lcccccc}
\hline \multirow{2}{*}{ Material } & \multicolumn{2}{c}{ First-stage stators } & & \multicolumn{2}{c}{ Second-stage stators } \\
& $\begin{array}{c}\text { Number } \\
\text { of blades }\end{array}$ & $\begin{array}{c}\text { Erosion rate } \\
\left(\mathrm{mg} / \mathrm{cm}^{2}-\mathrm{hr}\right)\end{array}$ & & $\begin{array}{c}\text { Number } \\
\text { of blades }\end{array}$ & $\begin{array}{c}\text { Erosion rate } \\
\left(\mathrm{mg} / \mathrm{cm}^{2}-\mathrm{hr}\right)\end{array}$ \\
\hline Nimonic 80A & 22 & 0.0146 & & 23 & 0.0248 \\
Stellite (H.S. 31) & 19 & 0.0307 & & 23 & 0.0250 \\
Chrome-plated surface & 7 & 0.0129 & & 14 & 0.0033 \\
\hline
\end{tabular}

The good wcar propeities of Llie chrome-placed blade surtaces in the second stage stator were probably due both to the corrosion resistance of this material and to its surface hardness. The high metal weight loss of these blades in the first stage stator was due to their location in the portion of the stator ring where the offset inlet to the turbine produced a high ash concentration and hence high wear rates. Microscopic inspection of a section of chromium-plated blade showed the ash deposit attached to a thin, well defined oxide film formed on the plated surface. There was no zone of alloy depletion and the surface of the parent metal, C.242, appeared to be completely protected by the plating. Failure of the surface coating due to thermal. cracking occurred on a number of blades in the vicinity of the leading and trailing edges.

The blade metal loss rates are not in themselves of any significance, except for the purpose of comparison, unless they are related to the ultimate life of a blade. A knowledge of blade life is of prime importance in determining the commercial feasibility of the coal-fired gas turbine system.

The most heavily eroded blades in the Ruston and Hornsby turbine were the rotor blades in the compressnr turbine. These were the original blades supplied with the engine and had been used for a Lutal of 35 houra without ash separatiun and 250 hours with the separator fitted to the engine. With gas cleaning, erosion occurs primarily on the concave face near the trailing edge; it was estimated from profile measurements on the original blade and at the end of the two test periods that the wear rate in this region withuul gat cleaning 13 some 60 to 70 times grealer than with the ash separator in the system. On this basis, the wear resulting from 35 hours without ash separation is equivalent to some 2,300 hours with ash separation; alternatively, the erosion of the concave face near the trailing edge produced during the test periods is equivalent to that resulting from about 2,500 hours of operation with ash separator fitted.

A stress analysis showed that the maximum stress (at the leading edge blade root) had increased by 14 percent through erosion. 
This increase resulted from undercutting of the leading edge root in the tests without ash separation; as the separator had practically eliminated this type of erosion the rate of stress increase with ash separation would be very low. Consequently the rotor blades in the compressor turbine, though worn, were considered to have a remaining useful life considerably in excess of the 2,500 hours equivalent operation estimated above.

The rates of metal loss in the power turbine were some 50 times lower than in the high pressure turbine during the 200-hour test. Visual inspection of these blades showed little sign of wear after the full complement of testing, and it was concluded that their useful life might be counted in tens of thousands of hours.

For the next series of turbine tests, a low-ash bituminous coal (Aberdare No. 7) from the Greta seam in New South Wales was used as the fuel. Typically, this coal contains 1 to $2 \%$ moisture, $5 \%$ ash, and $42 \%$ volatile matter. The experiments were designated as Greta tests 1, 2, 3, and 4. The following description of the tests is taken from Ref. 33:

\section{(a) Rotor blades}

The eroded blades removed from the compressor turbine at the conclusion of the Yalbourn brown coal tests were re-installed in the engine prior to Greta Test 1. A matched pair of new first and second row rotor blades were fitted at the start of Greta lest 1 for comparison with the blades which had been heavily eroded. Further erosion during Greta Tests 1 and 2 resulted in an excessive reduction in aerodynamic efficiency which necessitated replacement of all first and second stage rotor blades before the commencement of Greta Test 3; these blades were also used in Greta Test 4.

The blades of the power turbine which had been used throughout the Yalbourn brown coal tests were retalned for the four tests with Greta coal.

Stator blades

In addition to standard Nimonic-80A stator blades, samples of blades of various alloys and surface treatments were installed in the compressor turbine to evaluate their erosion resistance; the blades installed in each test are listed in Table A.14, and the material composition is given in Tih1e. A.8. The evaluation blades were distributed around the stator ring to offset the effect of uneven ash distribution caused by the elbow entry to the turbine. Blades of Nimonic $80 \mathrm{~A}$ and of other materials to be evaluated which were considered serviceable after operation in the earlier coal tests, were retained. The policy adopted for stator blade replacement was to discard any blades which showed excessive profile 
Table A.14. Compressor turbine stator blades (Ref. 33)

\begin{tabular}{|c|c|c|c|c|}
\hline \multirow{2}{*}{ Blade material } & \multicolumn{4}{|c|}{ Number of blades per stage evaluated } \\
\hline & Test 1 & Test 2 & Test 3 & Test 4 \\
\hline \multicolumn{5}{|c|}{ First stage } \\
\hline Nimonic $80 \mathrm{~A}$ & 23 & 13 & 17 & 16 \\
\hline Haynes Stellite H.S. 31 & 14 & 15 & 16 & 15 \\
\hline C. 242 & 5 & 5 & 8 & 8 \\
\hline N.155 & 5 & 7 & 5 & 5 \\
\hline Chromium plate & 14 & 15 & 15 & 15 \\
\hline Diffused chromium & 3 & 8 & 8 & 8 \\
\hline $\operatorname{Tota1}^{c}$ & $\overline{64}$ & $\overline{63}$ & $\overline{69}$ & $\overline{67}$ \\
\hline \multicolumn{5}{|c|}{ Second stage } \\
\hline Nimonic $80 \mathrm{~A}$ & 25 & 16 & 16 & 16 \\
\hline Haynes Stellite H.S. 31 & 13 & 10 & 13 & 13 \\
\hline C. 242 & & 5 & 16 & 16 \\
\hline N.155 & 4 & 3 & 3 & 3 \\
\hline Chromium plate $^{\alpha}$ & 23 & 24 & 15 & 15 \\
\hline Diffused chromium ${ }^{b}$ & & 3 & & \\
\hline & $\overline{65}$ & $\overline{6}$ & $\overline{6}$ & \\
\hline Tota 1 & 65 & 61 & 63 & 63 \\
\hline \multicolumn{5}{|c|}{$\begin{array}{l}a_{\text {Blades designated "chromium plate" were investment cast in }} \\
\text { the alloy C. } 242 \text { or H.R. Crown Max. and plated with a } 0.010-i n \text {. } \\
\text { layer of hard chromium plate. } \\
\text { bome H.S. } 31 \text {, C. } 242 \text {, and } \mathrm{N} .155 \text { blades were given a diffused } \\
\text { chromium coating approximately } 0.002 \text { in. deep by a proprietary pro- } \\
\text { cess known as the Diocrom Diffusion Coating Process. } \\
{ }^{a} \text { The total number of blades per stage is } 76 \text {. Balance of } \\
\text { blades were "pegged" and were not removed for evaluation. }\end{array}$} \\
\hline
\end{tabular}

weax; this was maiuly determincd by the degree lu which the trailing edge thickness had been reduced.

The original Nimonic $80 \mathrm{~A}$ stator blades in the power turbine were retained for all Greta tests.

During the Greta tests, the turbine inlet temperature was ma1ntained at $650^{\circ} \mathrm{C}\left(1202^{\circ} \mathrm{F}\right)$ to facilitate comparisons with the results from the Yalbourn brown coal tests; the turbine was calibrated with liquid fuel at the end of each test, and its performance related to that of an engine with new blading. 
During each test the weight of coal fed to the combustor and the weight of ash collected in the separator were measured. The major factors affecting the operation during the Greta tests are given below:

\section{(a) Greta Test 1 (17 hours)}

An inspection of the ash separator at the conclusion of this test.revealed damage to eight of the cyclones caused by after-burning within the separator.

(b) Greta Test 2 (1.3 hoirs)

The discharge tubes of the eight damaged cyclone units were blanked off prior to the start of the test; analysis of the results at the conclusion of this test showed a. reduction in separator efficiency compared with the first test, and that large solid particles were passing to the turbine. Atmospheric tests with the separator using sized silica showed that blanking off the discharge tube degraded the separator performance, and that this could only be restored by completely blanking off the damaged units.

(c) Greta Test 3 (10 hours)

Prior to the test:

(i) the eight damaged cyclone units were completely blanked off, reducing the number of effective units from 48 to 40 ;

(ii). both rotor stages of the compressor turbine were rebladed with new blades; some difficulty had been experienced in restarting the engine due to the low aerodynamic efficiency of the eroded blades at the end of Greta. Test 2;

(iii) a modified classifier was installed in the coal pulverising system to reduce the coal particle - size delivered to the combustor.

During the test the pulverizing system could not produce the required throughput of coal and liquid fuel was required to maintain a turbine inlet temperature of $650^{\circ} \mathrm{C}\left(1,202^{\circ} \mathrm{F}\right)$.

\section{(d) Creta Test 4 (20 hours)}

Modification to the classifier prior to the test resulted in satisfactory fineness gof grinding and rate of throughput.

The separator efficiency was based on the percentage of ash in the coal fed to the combustor and the amount collected in both the primary and secondary hoppers of the ash separator at the conclusion of the test. The percentage of carbon in ash samples taken from the separator hopper was less than 1 percent, indicating almost complete burn-out of the solids caught by the separator. 
The overall combustion efficiency for the combustion chamber, separator and turbine inlet ducting was determined from the carbon-to-solids ratio in samples collected at entry to the compressor turbine inlet.

The results for each of the tests is given in Table A.15.

the mean particle size of solids passing through the engine is given in Table A.16; the values for the intermediate turbine stages have been eliminated.

Inspection of both the compressor and power turbines at the conclusion of each test showed a light ash deposit on the surface of some of the first row stator blades of the compressor turbine. The deposit was limited to one quadrant of the stator assembly and is probably due to the non-uniformity of flow from the elbow to the turbine. There were no signs of ash deposit in the subsequent stages of the compressor or power turbines.

Turbine blade erosion was severe in all stages of the compressor turbine. In spite of a reduction of the mean particle size in Tests 3 and 4 to that achieved in Yalbourn brown coal experiments, the metal loss rate was about four times greater in the Greta-seam coal tests.

The matched pair of new first and second row rotor blades installed in the compressor turbine at the start of Greta 1 were examined at the end of Greta 2. They exhibit a smooth eroded surface on the concave face and evidence of trailing edge pitting and root erosion on the convex side. Deep etching of the convex surface of the blades retained from the previous Yalbourn brown coal test ( $285 \mathrm{hr}$ ) was evident. Microscopic examination of a blade section indicated evidence of impact damage probably caused during the earlier testing; again stator tip (inner diameter) leakage had resulted in a furrow on the convex surface of the rotor blade roots in both compressor turbine stages.

The compressor turbine rotors were rebladed at the conclusion of Test 2. Examination of the blades after completion of

Table A.15. Efficiency of combustion and ash separation Greta Teete 1 to 4 (Ref. 33)

\begin{tabular}{lllll}
\hline & 1 & 2 & 3 & 4 \\
\hline Combustion efficiency overall, \% & 94 & 91 & 98 & 98 \\
Separator efficiency, \% & 49 & 7 & 66 & 62 \\
Solids rate to turbine, kg/hr & 48 & 71.8 & $8.35^{a}$ & 13.2 \\
Mean particle size at turbine inlet, $\mu$ & 20.4 & 30.2 & $5.5-6.4$ & $6.0-8.0$ \\
Particulate content at turbine inlet, ppm $b \%$ & 1600 & 2400 & 285 & 442 \\
Particulate carbon content at turbine inlet, $\%$ & 58.8 & 64.3 & & 26.3 \\
\hline
\end{tabular}

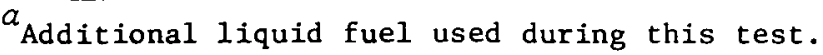

$b$ These values were derived from data taken from Ref. 35 .
} 
Table A.16. Mean particle size through engine - Greta Tests 1 to 4 (Ref. 33)

\begin{tabular}{ccccc}
\hline Test & $\begin{array}{c}\text { Entry } \\
\text { 1st stage } \\
\text { stator } \\
(\mu)\end{array}$ & $\begin{array}{c}\text { Entry } \\
\text { 2nd stage } \\
\text { statora } \\
(\mu)\end{array}$ & $\begin{array}{c}\text { Entry } \\
\text { 3rd stage } \\
\text { stator } \\
(\mu)\end{array}$ & $\begin{array}{c}\text { Entry } \\
\text { 4th stage } \\
\text { statora } \\
(\mu)\end{array}$ \\
\hline & 22 & 20.5 & 19.3 & 18 \\
1 & 30 & 28.3 & 26.5 & 24.8 \\
2 & $5.5-6.4$ & $5.2-6.0$ & $4.8-5.6$ & $4.4-5.2$ \\
3 & $6.0-8.0$ & $5.6-7.5$ & $5.3-7.0$ & $4.8-6.5$ \\
4 & & &
\end{tabular}

Test 4 showed that the erosion rate had been considerably reduced compared with Tests 1 and 2, although erosion near the root of the leading edge is still apparent. Pitting at the trailing edge was practically eliminated and the erosion pattern was similar to that with Yalbourn brown coal operation.

Severe erosion of the stator blades in both rows of the compressor turbine was evident at the conclusion of Tests 1 and 2 . This was most marked on the concave (pressure) face of the blade in a region extending from mid-span to the outer diameter. Some surface pitting had occurred on the suction face close to the blade trailing edge. There were similar erosion patterns at the conclusion of Tests 3 and 4 but the rate of metal loss was very much reduced.

The erosion damage to the blading in the power turbine was much less than that measured in the corresponding stages of the compressor turbine. The areas affected were substantially the same, but the rate of erosion in the worst case (Greta Test 2) was about equal to the lowest erosion rate measured for the compressor turbine rotor blades during opcration with Yalbourn brown coal:

The original blade material, Nimonic $80 \mathrm{~A}$, exhibited the highest erosion rate of the blade alloys and surface treatments evaluated, while the erosion resistance of hard chromium plate was superior to all other blades tested; however, some surface failures occurred due to thermal cracking and crazing of the chromium layer.

The stator blades treated by the chromium diffusion process exhibited low erosion rates and were not subject to surface failure. Spalling of the oxide layer on the C.242 and H.S. 31 blades which had occurred during Yalbourn brown coal testing, and which was thought to be influenced by corrosion, was not evident. 
After the completion of the Greta seam coal tests, a 10-hr test was carried out with Callide coal from Central Queensland. Typically, this coal contains 8 to $15 \%$ moisture, $15 \%$ ash, and 26 to $28 \%$ volatile matter. The following description of the test is taken from Ref. 33:

Stator blades of various alloys and surface treatments were installed in the compressor turbine to evaluate their resistance to erosion. Tables A.17 and A.18 give the blade materials and surface treatments used, and the blade history at the start of the test, while Table A.8 lists the blade material compositions.

In addition to the alloys used in the test, a number of stator blades were treated by proprietary surface coatings; these are listed in Table A. 19 .

The various surface treatment methods (taken from Ref. 35) were:

(a) Metal spraying

The P1.asma Jet method was used to spray surface coatings of alumina (L. $\Lambda .2$ ) and tungsten carbide (L.W.1) to the base metal H.S.31. The coating thickness varied from 0.005 in. to 0.010 in. ( 0.13 to 0.26 $\mathrm{mm}$ ) and covered the whole of the blade surface apart from the root which was masked during the process.

Table A.17. Compressor turbine first-stage stator blades (Rcf. 35)

\begin{tabular}{|c|c|c|c|c|}
\hline \multirow{2}{*}{ Blade material } & \multicolumn{4}{|c|}{ Blade history } \\
\hline & $\begin{array}{l}\text { New } \\
\text { blades }\end{array}$ & Us & $\begin{array}{l}\text { sed in } \\
\text { coal test }\end{array}$ & Total \\
\hline Nimonic $80 \mathrm{~A}$ & & & 10 & 10 \\
\hline $\begin{array}{l}\text { L..A.2. Al.umina conat.ing nn } \\
\text { H.S. } 31\end{array}$ & 3 & & & .3 \\
\hline $\begin{array}{l}\text { L.W.1 Tungsten carbide on } \\
\text { H.S. } 31\end{array}$ & 3 & & & 3 \\
\hline H.S. 31 & 12 & & & 12 \\
\hline Chromium plate on H.S. 31 & 12 & & & 12 \\
\hline N. 155 & 3 & & 3 & 6 \\
\hline C. 242 & 6 & & & 6 \\
\hline H.R. Crown Max & 6 & & & 6 \\
\hline $\begin{array}{l}\text { L.W. } 5 \text { Tungsten and chromium } \\
\text { carbides on H.S. } 31\end{array}$ & 6 & & & 6 \\
\hline Diffused chromium on H.S. 31 & 8 & & & 8 \\
\hline
\end{tabular}


Table A.18. Compressor turbine second-stage stator blades (Ref. 35)

\begin{tabular}{|c|c|c|c|}
\hline \multirow{2}{*}{ Blade material } & \multicolumn{3}{|c|}{ Blade hịstory } \\
\hline & $\begin{array}{l}\text { New } \\
\text { blades }\end{array}$ & $\begin{array}{l}\text { Used in } \\
\text { Greta coal test }\end{array}$ & Total \\
\hline Nimonic $80 \mathrm{~A}$ & & 7 & 7 \\
\hline L.A. 2 Alumina coating on H.S. 31 & 3 & & 3 \\
\hline L.W.l Tungsten carbide on H.W. 31 & 3 & & 3 \\
\hline H.S. 31 & 9 & & 9 \\
\hline Chromium plate on H.S. 31 & 11 & 3 & 14 \\
\hline N. 155 & 3 & 4 & 7 \\
\hline C. 242 & 7 & 6 & 13 \\
\hline H.R. Crown Max. & & 8 & 8 \\
\hline $\begin{array}{l}\text { L.W. } 5 \text {; Tungsten and chromium } \\
\text { carbides on H.S. } 31\end{array}$ & 5 & & 5 \\
\hline Diffused chromium on H.S. 31 & 7 & & 7 \\
\hline
\end{tabular}

The blades identified as L.W.5 in Table A.19 were also metal-sprayed using the "Detonation Flame Plating" process developed by Union Carbide Corporation. In this case only the concave surface and blade leading edge were treated, the coating thickness being about 0.003 in. $(0.08 \mathrm{~mm})$.

A description of the blade coatings is given in Table A.19.

(b) Diffused chromium

Investment cast bliades in H.S. 31 were pack chromised at approximately $1,100^{\circ} \mathrm{C}\left(2,012^{\circ} \mathrm{F}\right)$ using a process patented by Metal Diffusions Limited of Britain.

(c) Chromium plate

A number of H.S. 31 blades were plated with hard chromium. To minimize the thermal cracking which had occurred in earlier tests the coating thickness was reduced to 0.007 in. $(0.18 \mathrm{~mm})$ and the blade tips radiused to improve adhesion.

The rotor blades in both stages of the compressor turbine installed at the start of Greta Test 3 were retained, as were the original Nimonic-80A blades used in all stages of the power t.urhine. 
Table A.19. Metal-sprayed stator blades (Ref. 33)

\begin{tabular}{|c|c|c|c|c|}
\hline $\begin{array}{l}\text { Blade } \\
\text { material }\end{array}$ & Coating & Composition & $\begin{array}{l}\text { Hardness } \\
\text { (V.P.N.) }\end{array}$ & $\begin{array}{c}\text { Maximum working } \\
\text { temperature } \\
{\left[{ }^{\circ} \mathrm{C}\left({ }^{\circ} \mathrm{F}\right)\right]}\end{array}$ \\
\hline H.S. 31 & Alumina (L.A.2) & $99 \% \mathrm{Al}_{2} \mathrm{O}_{3}$ & 1100 & $982(1800)$ \\
\hline H.S. 31 & Tungsten carbide (L.W.1) & Tungsten carbide $+9 \% \mathrm{Co}$ & 1300 & $538(1000)$ \\
\hline H.S. 31 & Tungsten/chromium (L.W.5) & $\begin{array}{l}25 \% \mathrm{WC}+5 \% \mathrm{Ni}+\text { mixed } \\
W-\mathrm{Cr} \text { carbides }\end{array}$ & 1075 & $760(1400)$ \\
\hline
\end{tabular}

The separator efficiency was based on the weight of ash collected in the separator, together with the ash content of the coal and total coal fed to the combustor. Burn-off tests of samplec recovered from the hopper ohowed inoignificant carbon content, indicating complete burn-out of the larger carbon particles in the scparator. The quantity of solids entering the turbine includes the ash not collected in the separator together with an unburnt carbon content, as determined by standard burn-off tests. The greatest possible error in the solids loading has been estimated as \pm 13 percent.

Table A.20 summarizes the performance of the combustion chamber and ash separator.

Inspection of both the compressor and power turbines at the conclusion of the test showed no apparent ash deposits, although a close inspection revealed small areas of deposit on the concave surface of a few stator blades in the first row of the cumpressur Lurbline.

The erosion patterns on the various blades were very similar to those produced in Greta Tests 3 and 4; the highest erosion rate occurred in the first stage rotor blades of the compressor turbine which show light erosion on the root section near the blade leading edges and on the pressure face towards the trailing edge. The power turbine blades have been used in all tests and showed little wear.

The stator blades in the compressor turbine showed erosion in the region of the trailing edge tip and on the pressure face towards the trailing edge, with some surface pitting on the suction face close to the trailing edge.

As in the Greta coal tests, the material most susceptible to particle erosion was Nimonic $80 \mathrm{~A}$, the original blade material. The ratio of wear rates between these blades and those treated by chromium plating was approximately $6: 1$ and $8: 1$ in the first and second stator rows respectively.

The first row stator blades treated by the chromium diffusion process initially showed a slight weight gain after 1 hour 
Table A.20. Combustor and separator efficiency (Ref. 33)

\begin{tabular}{ll} 
Combustion efficiency, \% (including separator and ducts) & 98 \\
Separator efficiency, \% & 65 \\
Solids rate to turbine, $\mathrm{kg} / \mathrm{hr}$ & 52.2 \\
Mean particle size, $\mu$ & \\
$\quad$ Entry to compressor turbine & $4.6-6.4$ \\
$\quad$ Entry to power turbine & $4.0-6.0$ \\
$\quad$ Exhaust duct & $4.0-4.2$ \\
Particulate content at turbine inlet, ${ }^{\alpha} \mathrm{ppm}$ & 1740 \\
Particulate carbon content at turbine inlet, ${ }^{*} \%$ & 30 \\
\hline$a_{\text {The values were derived from data taken from Ref. } 35 .}$
\end{tabular}

of operation and at the end of the test had not achieved a stabilized rate of erosion. With the higher level of erosion occurring in the second stage of stator blades, a reasonable weight loss did result; the ratio of the metal removed from the chromium diffused blades to that removed from the Nimonic blades was about $1: 10$.

of the other materials tested, H.S. Crown Max. and H.S. 31 exhibited the greatest resistance to erosion, whilst those blades treated by the "Plasma Jet" or the "Detonation Flame Plating" process proved unsatisfactory in a number of cases, due possibly to faulty processing causing coating failures.

Sections taken from four different blades were subjected to metallographic examination to determine if corrosion of the blade. material had occurred; no indication of any deterioration could be found, and in each case a well defined oxide layer was evident.

\section{Modified Ruston and Hornsby "TA" Turbine}

After the Callide coal test, examination of all the erosion data indicated that operation using a low-ash coal as fuel and ash separation that the life of the blades in the compressor turbine was between 2500 and 5000 hr. The estimated life of the blades in the power turbine was at least an order of magnitude greater. ${ }^{33}$ The major difference in the operating conditions in the two turbines was the gas velocity. The gas velocity was approximately $1100 \mathrm{fps}(335 \mathrm{~m} / \mathrm{sec})$ in the compressor turbine and $800 \mathrm{fps}$ $(244 \mathrm{~m} / \mathrm{sec})$ in the power turbine. The lower gas velocity and consequently lower particle velocity results in a decrease in metal. loss per impact. 
In addition to the reduction in metal loss resulting from the lower impact velocity, the larger annular area required for the same mass flow at lower velocity results in an increased blade area and a corresponding reduction in the unit particulate concentration.

The compressor turbine was redesigned to have velocities of approximately $800 \mathrm{fps}(244 \mathrm{~m} / \mathrm{sec})$ and at the same time incorporate other features believed to be important in extending blade life. A description of the redesigned compressor turbine is taken from Ref. 33:

Calibration of the original engine on coal following the installation of the ash separator showed that the running line on the compressor characteristic differed slightly from that in the general performance data provided by Ruston and Hornsby as being typical of a "TA" turbine operating on oil. A point on the former characteristic was chosen as the design point; this corresponded to a turbine inlet temperature of $650^{\circ} \mathrm{C}\left(1,202^{\circ} \mathrm{F}\right)$ which is somewhat lower than the maximum cycle temperature of the original engine. This value had been selected in the initial tests and was retained to facilitate direct comparisons between the results of the various tests. The turbine speed at the design point was 10,200 r.p.m.

The relative gas exit velocity at the mean radius of the rotor blades was about $1,100 \mathrm{ft} / \mathrm{sec}(335 \mathrm{~m} / \mathrm{s})$ at the derated condition of the original compressor turbine. Preliminary estimates showed that with velocities of $800 \mathrm{ft} / \mathrm{sec}(244 \mathrm{~m} / \mathrm{s})$ insufficient power would be available from a two-stage turbine built within the original engine scantlings, even with close to the maximum practical gas deflection. Consequently a three-stage rotor was necessary. Fortunately it was possible, by adaptation of the shaft, bearing, and casing in the region of the compressor turbine, to accommodate the three turbine stages without major structural alteration. A design was then prepared for this arrangement based on a gas velocity of about $800 \mathrm{ft} / \mathrm{sec}(244 \mathrm{~m} / \mathrm{s})$, although this meant that other important design conditions such as blade efficiency, reaction, etc. could not be given primary considerations. The basic dimensions of the turbine were so chosen that it was possible to use the first, second, and fnurth stage. rotor discs of the Ruston and Hornsby "TF" gas turbine which is another model produced by this maker. These discs were obtained in the fully machined condition from the manufacturer and were adapted for use with the redesigned engine; this determined the number of rotor blades per stage (57), and also fixed the maximum axial blade chord.

'l'he required temperature drop through the turbine was calculated from the compressor temperature rise based on an inlet temperature of $15^{\circ} \mathrm{C}\left(59^{\circ} \mathrm{F}\right)$ and a compressor isentropic efficiency of 0.80 ; the latter is lower than the value of 0.825 quoted for the 
original engine, and was used to allow for possible deterioration in performance caused by compressor blade fouling by contaminated intake air. The work output was shared equally between the three stages, as this results in approximately equal velocities in each stage.

Velocity triangles for the stator and rotor rows were constructed to give the required work output, using trial values of pressure loss and gas velocity; the nozzle velocity was made about $100 \mathrm{ft} / \mathrm{sec}(30 \mathrm{~m} / \mathrm{s})$ greater than the rotor relative velocity, as it was considered likely that more erosion could be tolerated on the stator blades before the occurrence of an unacceptable reduction in performance.

Additional features were incorporated into the design to limit the high erosion rate found in localized areas of the original blades.

Apart from the gross maldistribution of ash produced by the angle entry to the turbine, local concentrations result from a number of features of the gas flow within the turbine stages; these have been described by Junge (Ref. 32) during the work of the U.S. Locomotive Development Committee. The main features are:

(a) A concentration of particles of the pressure face of the blade toward the trailing edge, produced by deflection of the gas stream through the blades.

(b) The transport of ash towards the outer boundary by

(i) centrifugal forces produced by the tangential velocity components in the blade passages;

(ii) centrifugal forces on particles in regions of separated flow on convex face and in the wake of the rotor blade.

(c) The transport of ash towards the inner boundary resulting from a static pressure gradient which produces an inward flow of gas and particles in regions of separated flow on the convex face and in the wake of the stator blade.

(d) The transport of ash towards both the inner and outer walls is assisted by vortices formed at the blade tips and roots; gas and ash from the blade boundary layer (particularly on the pressure face) tend to feed into these vortices, thus reaching the side walls. This is termed cross channel flow. In the case of a nozzle with a moving inner side wall, the gas and ash may move down the blade and under the tip rather than cross the passage.

These conslderations led to the inclusion of the following design features. The trailing edge thickness of both the stator and rotor was increased to $0.060 \mathrm{in}$. $(1.5 \mathrm{~mm})$ to provide more metal which must be removed from the pressure face before the blade chord would be affected. This could increase the aerodynamic losses, but the economic consequence of the latter should be outweighed by the increase in time between blade replacements. Aerodynamic performance is unlikely to deteriorate with erosion unt1l the blade chord 
is affected; in fact the engine power could increase slightly as erosion thins the trailing edge and the trailing edge losses are reduced.

This modification increases the size of the stator blade trailing edge wake, and hence the amount of ash fed to the inner diameter, and from there into the stator tip leakage flow. Thus the amount of ash eventually impinging on to the rotor blade leading edge could be increased. To limit this action and yet retain thick trailing edges, mid-span stator wake fences were built into the stator blades to redistribute portion of the ash into the main gas stream.

To limit the effect of ash reaching the inner boundary and striking the rotor leading edge, the stator blade tips were recessed into the inner boundary below the level of the rotor blade ruot, so that most erosion would occur on the hlade platform rather than on the working surfaces of the blade itself.

The rotor blade platform section was extended to form the recessed stator blade tip boundary and to provide a gap to control turbine disc and root cooling air flows.

No special measures were taken to limit local erosion of the roots (O.D.) of the stator blades produced by ash concentrations on the outer wall. These blades are lightly stressed and it was considered unlikely that any serious problem would arise.

Because of the highly twisted blade profile, the compli.icated blade platform section and the relative costs of production, both rotor and stator blades in the compressor turbine were investment cast. in the cobalt based alloy H.S. 31 . In each of the three stator stages, four blades surface-treater by the Interchrome process of chromium; both produce dtffusinntype surface alloying which is dependent on the substrate composition.

The carbon content of the base alloys tends to stabilize the depth to which the coating can diffuse. In the Interchrome process it was considered that a depth of 0.0005 in. $(0.013 \mathrm{~mm})$ of hard coaring with good oridation rcsistance had beeii uludinted. The U.C. process of aluminizing produced a depth of diffusion of 0.0015 in. $(0.038 \mathrm{~mm})$, consisting of inner and outer layers of approximately equal thickness.

The Nimonic-80A blades originally fitted to both rotor and stator rows of the power turbine and used in all earlier engine tests were retained.

Before commencing solid fuel tests on the Ruston and Hornsby engine with the redesigned compressor turbine, the unit was calibrated on liquid fuel to determine if the thermodynamic and mechanical design requirements had been fulfilled.

After two hours running at idling conditions the compressor turbine was dismantled, inspected and dimensionally checked for 
signs of distortion of new parts. No mechanical anomalies were detected in this or in subsequent inspections at various stages throughout the test programme with solid fuel.

The unit was then operated at progressively increasing load to the maximum turbine inlet temperature of $650^{\circ} \mathrm{C}\left(1,202^{\circ} \mathrm{F}\right)$, and performance data recorded over the full range of operating conditions.

The design velocity triangles for the redesigned compressor turbine, assuming equal work output per stage, were compared with those estimated from the results of the calibration. In both cases the turbine inlet temperature is $650^{\circ} \mathrm{C}\left(1,202^{\circ} \mathrm{F}\right)$, but the compressor speed at the design point was 10,200 r.p.m. compared with 10,500 r.p.m. during the calibration. The relevant data is listed for all three stages in Table A.21; it will be seen that the velocities at exit from the stators $\left(V_{0}\right)$ and rotors $\left(V_{1}\right)$, and the corresponding gas angles $\alpha_{0}$ and $\alpha_{2}$, are similar to the design values.

Table A.21. Comparison of design and measured velocity triangles (Ref. 33)

Turbine entry temperature $=650^{\circ} \mathrm{C}\left(1202^{\circ} \mathrm{F}\right)$

Compressor speed $=10,200 \mathrm{rpm}$

\begin{tabular}{|c|c|c|c|c|c|c|}
\hline & \multicolumn{3}{|c|}{ Design data for stage - } & \multicolumn{3}{|c|}{$\begin{array}{l}\text { Experimental data } \\
\text { for stage - }\end{array}$} \\
\hline & 1 & 2 & 3 & 1 & 2 & 3 \\
\hline $\begin{array}{l}U \text {, blade speed, fps } \\
V_{0} \text {, nozzle outlet velocity, fps } \\
V_{1} \text {, rotor outlet velocity, fps } \\
\alpha_{0} \text {, nozzle gas angle } \\
\alpha_{2} \text {, rotor gas angle }\end{array}$ & $\begin{array}{l}740 \\
877 \\
776 \\
66^{\circ} 8^{\prime} \\
63^{\circ} 31^{\prime}\end{array}$ & $\begin{array}{l}763 \\
864 \\
780 \\
66^{\circ} 59^{\prime} \\
64^{\circ} 9^{\prime}\end{array}$ & $\begin{array}{l}786 \\
827 \\
821 \\
65^{\circ} 59^{\prime} \\
64^{\circ} 55^{\prime}\end{array}$ & $\begin{array}{l}762 \\
865 \\
770 \\
65^{\circ} 48^{\prime} \\
63^{\circ} 30^{\prime}\end{array}$ & $\begin{array}{l}785 \\
836 \\
789 \\
66^{\circ} 26^{\prime} \\
65^{\circ} 8^{\prime}\end{array}$ & $\begin{array}{l}809 \\
800 \\
865 \\
65^{\circ} 36^{\prime} \\
66^{\circ} 29^{\prime}\end{array}$ \\
\hline
\end{tabular}

After calibration of the engine with liquid fuel, the engine was operated with solid fuel. The fuel used was a low ash, high volatile Greta-seam coal from the Aberdare No. 7 mine. Typically this coal contains 1 to $2 \%$ moisture, 5 to $7 \%$ ash, and 39 to $42 \%$ volatile matter.

The following description of the test is taken from Ref. 33:

Following a preliminary run of 18.4 hours to check that the particle size in the coal feed and the combustion efficiency were unaltered from those in Greta Test 4, further runs of 33.0, $29.1,19.1$ and 15.2 hours were undertaken, making a total of 124.8 hours operation with coal. Table A.22 summarizes the performance of the combustion chamber and ash separator. 
Table A.22. Combustor and separator efficiency (Ref. 36)

\begin{tabular}{ll} 
Combustion efficiency overall, \% & 98 \\
Separator efficiency, $\%$ & 60 \\
Solids rate to turbine, $\mathrm{kg} / \mathrm{hr}$ & 22.3 \\
Mean particle size, $\mu \mathrm{m}$ & \\
$\quad$ Entry to compressor turbine & $4.3-7.8$ \\
Exhaust duct & $3.0-7.5$ \\
Particulate carbon content at turbine inlet, \% & 46.4 \\
Particulate content at turbine inlet, ppm & 650 \\
\hline
\end{tabular}

At the conclusion of each test period the following blades were cleaned and weighed:

(a) Compressor turbine

(i) all stator blades including those with surface treatment, but excepting the eight per row located by dowels;

(ii) three blades spaced 120 degrees apart in each rotor stage. (b) Power turbine

(i) ten stator blades in each row (a further ten were weighed at the beginning and end of the test series);

(ii) one rotor blade per stage.

Calibration of the engine on oil at the end of the test series showed that there was no detectable change in performance from that measured in the earlier calibrations.

As in the previous tests with Callide coal there was 1it.t.1e ash deposition on the turbine blades. Deposition was restricted to the first row stators of the compressor turbine, where a light film of ash extended from the leading edge to a maximum of about one th1rd of the blade chord, with its location and extend depending on its position in the blade row. Moving around the stator from the inlet duct the film on the convex fact contracted to the leading edge over 180 degrees around the row, and then gradually extended over the concave face over the remaining 180 degrees. This indioatec a progreosive change in gas incidence angle around the stator. row, probably produced by the elbow entry to the inlet volute.

A very thin, hard deposit had formed along the stagnation line on the leading edge of all blades in all rotor and stator rows.

The progressive metal loss from the rotor blades was plotted against hours of engine operation on coal; the curves show that the rate of metal loss was initially high, but decreased during the first 50 hours of the test to a stable value for the remainder of the test. This constant value of erosion rate for the final 
73.4 hour period was accepted as the stable erosion rate and was used as the basis for blade life estimation.

The rotor blades in the power turbine had been used in previous tests with pulverized fuel, and their erosion rates were constant over the whole test period.

Table A.23 gives the blade metal losses and erosion rates for the final 73.4-hour period for all weighed rotor blades of the compressor turbine, and for a 106-hour period for the power turbine.

The trend for a higher erosion rate in the first stage than the second stage of the compressor turbine, and for comparable erosion rates in both stages of the power turbine, was also obtained in earlier tests on the original turbine with pulverized coals.

As with the rotor blades the wear rate of each stator blade in the redesigned compressor turbine stabllized over the first 50 hours of the test, and remained at a constant value for the remaining 73.4 hours.

The elbow entry of the inlet volute carrying the hot gas stream from the ash separator causes a non-uniformity in ash loading at inlet to the first row of stator blades. This results in a variation in the blade metal loss around the stator ring, with a peak opposite the entry to the volute; this pattern of blade wear persists throughout the remaining high pressure stator stages, but in the second and third stages the peaks of maximum erosion are progressively displaced in the direction of rotor rotation due to swirl through the stages. The blade metal loss, and erosion rates for all stator rows, are summarized in Table A.24.

The wear rates on the diffusion coated blades were much lower than those measured on adjacent H.S. 31 cobalt based blades. In Table A.25 four groups of blades from each stator stage of the high pressure turbine are compared. The blades in each group were adjacent and the groups equispaced around the stator casing. The negative sign indicates a weight loss, the positive sign a weight gain.

Unlike the H.S. 31 blades, few of the surface treated blades attained a stabilized erosion rate over the last 73.4 hours of the test. The four chromized blades in the first stator row showed the most consistent wear rates, the average metal loss being approximately one fifth that of the untreated H.S. 31 blades; this relative value had also been obtained in previous tests. In the second and third stator row the chromized blades exhibited a change in weight varying from a loss of 31.6 milligrams to a gain of 4 milligrams without any consistent trend. Similarly, the aluminized blades in all rows showed a weight change varying from a loss of 8.3 milligrams to a gain of 6.0 milligrams without any consistent trend.

Three blades from the first stage stator, one chromized, one aluminized and one untreated, were subjected to metallographic 
Tabie A.23. Rotor blade erosion data - soiids loading $22.3 \mathrm{~kg} / \mathrm{hr}$

\begin{tabular}{|c|c|c|c|c|c|c|c|c|c|}
\hline & \multirow{2}{*}{ Stage } & \multirow{2}{*}{$\begin{array}{c}\text { Blade area } \\
\left(=\mathrm{m}^{2}\right)\end{array}$} & \multirow{2}{*}{$\begin{array}{l}\text { No. of } \\
\text { blades }\end{array}$} & \multirow{2}{*}{ Blade No. } & \multirow{2}{*}{$\begin{array}{l}\text { Metal loss } \\
(\mathrm{mg})\end{array}$} & \multicolumn{3}{|c|}{ Blade erosicn rate } & \multirow{2}{*}{$\begin{array}{l}\text { Stage erosion rate } \\
(\mathrm{mg} / \mathrm{kg} \text { ash) }\end{array}$} \\
\hline & & & & & & $\mathrm{mg} / \mathrm{cm}^{2} \times \mathrm{hr}$ & (mg/cr. & $\pi^{2}: \mathrm{kg}$ ash) $\times 10^{3}$ & \\
\hline & & Three-stage & c Jmpressor & turbine $(73$ & 4-hr period): & Ruston \& Hornst & "TA" g & gas turbine (Ref. 3 & 33) \\
\hline 1 & (H.S. 31) & 53.6 & 57 & $\begin{array}{r}1 \\
19 \\
38 \\
\text { Av }\end{array}$ & $\begin{array}{l}82.5 \\
73.6 \\
76.5 \\
77.5\end{array}$ & $\begin{array}{l}0.021 \\
0.019 \\
0.020 \\
0.020\end{array}$ & & $\begin{array}{l}3.945 \\
3.243 \\
3.876 \\
3.89\end{array}$ & 2.71 \\
\hline 2 & (H.S. 31) & 52.6 & 57 & $\begin{array}{r}1 \\
19 \\
38 \\
\text { Av }\end{array}$ & $\begin{array}{l}56.0 \\
53.7 \\
54.3 \\
54.7\end{array}$ & $\begin{array}{l}0.012 \\
0.012 \\
0.012 \\
0.012\end{array}$ & & $\begin{array}{r}0.55 \\
0.53 \\
0.53 \\
0.54\end{array}$ & 1.91 \\
\hline \multirow[t]{2}{*}{3} & (H.S. 31) & 57.4 & 57 & $\begin{array}{l}1 \\
19 \\
38 \\
\text { Av }\end{array}$ & $\begin{array}{l}65.8 \\
64.2 \\
69.2 \\
66.4\end{array}$ & $\begin{array}{l}0.013 \\
0.013 \\
0.014 \\
0.013\end{array}$ & & $\begin{array}{l}3.60 \\
3.59 \\
3.63 \\
3.61\end{array}$ & 2.32 \\
\hline & \multicolumn{9}{|c|}{ Two-s-age power turbine ( $106-\mathrm{hr}$ period) } \\
\hline 1 & (Nimonic 80A) & 52 & 97 & 24 & 112.5 & 0.020 & & 3.908 & 4.58 \\
\hline 2 & (Nimonic $80 \mathrm{~A}$ ) & 59 & 97 & 24 & 122.8 & $0.0 \pm 9$ & & 0.873 & 5.00 \\
\hline
\end{tabular}


Table A.24. Stator blade erosion data - solids loading $22.3 \mathrm{~kg} / \mathrm{hr}$

\begin{tabular}{|c|c|c|c|c|c|c|}
\hline \multirow{2}{*}{ Stage } & \multirow{2}{*}{$\begin{array}{l}\text { Blade area } \\
\qquad\left(\mathrm{cm}^{2}\right)\end{array}$} & \multirow{2}{*}{$\begin{array}{l}\text { No. of } \\
\text { blades }\end{array}$} & \multirow{2}{*}{$\begin{array}{c}\text { Metal loss per } \\
\text { blade } \\
\text { (mg) }\end{array}$} & \multicolumn{2}{|c|}{ Blade erosion rates } & \multirow{2}{*}{$\begin{array}{l}\text { Stage erosion rate } \\
\text { (mg/kg ash) }\end{array}$} \\
\hline & & & & $\mathrm{mg} / \mathrm{cm}^{2} \times \mathrm{hr}$ & $\left(\mathrm{mg} / \mathrm{cm}^{2} \times \mathrm{kg}\right.$ ash $) \times 10^{3}$ & \\
\hline
\end{tabular}

Three-stage compressor turbine (73.4-hr period): Ruston \& Hornsby "TA" gas turbine (Ref. 33)

\begin{tabular}{|c|c|c|c|c|c|c|c|}
\hline 1 & (H.S. 31) & 47.6 & 64 & $\begin{array}{r}80.8 \text { max } \\
4.6 \text { min } \\
32.5 \text { mean }\end{array}$ & 0.0094 & 0.42 & 1.28 \\
\hline 2 & (H.S. 31) & 66.6 & 48 & $\begin{array}{r}202.9 \text { max } \\
37.3 \text { min } \\
95.1 \text { mean }\end{array}$ & 0.020 & 0.88 & 2.80 \\
\hline 3 & (H.S. 31) & 81.6 & 48 & $\begin{array}{r}170.2 \text { max } \\
55.6 \text { min } \\
106.5 \text { mean }\end{array}$ & 0.018 & 0.80 & 3.14 \\
\hline \multicolumn{8}{|c|}{ Two-stage power turbine (106-hr period) } \\
\hline 1 & (Nimonic $8(\mathrm{AA})$ & 60 & 92 & $\begin{array}{l}133.7 \text { max } \\
102.7 \text { min } \\
117.0 \text { mean }\end{array}$ & 0.0183 & 0.82 & 4.52 \\
\hline 2 & (Nimonic $8(\mathrm{AA})$ & 67 & 92 & $\begin{array}{l}235.8 \mathrm{max} \\
155.0 \mathrm{~min} \\
186.3 \mathrm{mean}\end{array}$ & 0.026 & 1.16 & 7.19 \\
\hline
\end{tabular}


Table A.25. Comparison of untreated and surface treated H.S. 31 stator blades

(Ref. 33)

\begin{tabular}{|c|c|c|c|}
\hline \multirow[t]{2}{*}{ Treatment } & \multicolumn{3}{|c|}{$\begin{array}{l}\text { Weight change per } \\
\text { blade in } 73.4 \mathrm{hr} \\
\text { (mg) }\end{array}$} \\
\hline & Stage 1 & Stage 2 & Stage 3 \\
\hline $\begin{array}{l}\text { Chromized } \\
\text { Aluminized } \\
\text { Untreated }\end{array}$ & $\begin{array}{r}-4.0 \\
+5.7 \\
-36.0\end{array}$ & $\begin{array}{r}-23.0 \\
+0.3 \\
-110.1\end{array}$ & $\begin{array}{r}-5.2 \\
-8.3 \\
-125.4\end{array}$ \\
\hline $\begin{array}{l}\text { Chromized } \\
\text { Aluminized } \\
\text { Untreated }\end{array}$ & $\begin{array}{r}-7.5 \\
+5.3 \\
-24.7\end{array}$ & $\begin{array}{r}+4.6 \\
+6.0 \\
-40.8\end{array}$ & $\begin{array}{r}+3.4 \\
+0.7 \\
-61.7\end{array}$ \\
\hline $\begin{array}{l}\text { Chromized } \\
\text { Aluminized } \\
\text { Intreated }\end{array}$ & $\begin{array}{r}-7.3 \\
-5.1 \\
-22.7\end{array}$ & $\begin{array}{r}-31.6 \\
-5.6 \\
-78.2\end{array}$ & $\begin{array}{r}-20.5 \\
-6.5 \\
-172.9\end{array}$ \\
\hline $\begin{array}{l}\text { Chromized } \\
\text { Aluminized } \\
\text { Untreated }\end{array}$ & $\begin{array}{r}-8.8 \\
+3.0 \\
-35.0\end{array}$ & $\begin{array}{r}+1.4 \\
+1.1 \\
-67.4\end{array}$ & $\begin{array}{r}-1.7 \\
-4.4 \\
-77.5\end{array}$ \\
\hline
\end{tabular}

examination and the following conclusions reached:

(1) The metallurgical structure of the blades appeared satisfactory.

(2) The untreated H.S. 31 blade had suffered some surface pitting and possibly limited penetration [to about 0.0004 in. $(0.01$ $\mathrm{mm})$ ] of the turbine gases at the operating temperatures.

(3) The chromized blade had withstood the operating conditions better than the untreated blade and the blade surface remaincd amooth. The protcctive chromised layer was reduced to about half its original thickness [i.e., to 0.00025 in. (U. UU6 Inul) ] during the operating life of the blade.

(4) The aluminized blade had also withstood the operating condilluns wlthuut vistble change to lis metallurglcal structurc; howcver, the upper layer anffered some surface pitting and erosion. The coating was apparently reduced from an original thickness of approximately 0.0015 in. to 0.0009 in. $(0.038$ to $0.023 \mathrm{~mm})$ due mainly to the removal of the upper layer.

T,f it is assumed that this thickness of material was removed from the entire blade surface then the weight loss after 73.4 hours of operation would be many times greater than that actually measured. These reductions in layer thickness should, therefore, be 
interpreted only as indicating some change in the nature of the diffusion coating.

Hence, neither the long term behaviour of the surface treated blades, nor the estimated time of operation before resurfacing becomes necessary, can be predicted from these tests.

Examination of the blades on the completion of the 124.8 hours of operation showed various degrees of polishing in local areas of the blade surface, but insufficient metal had been removed to permit a realistic measurement of the depth of erosion. However from the degree of polishing, surface texture and colour it was possible to grade the erosion rate in specific areas of a blade into one of four relative categories:

"High" erosion

"Medium" erosion

"Low" erosion

"No" erosion

On the concave face of the first row stator blades the rate of erosion was "low" to "medium" over the rear half of the blade. The location of an area of "high" erosion varied with the position of the blade around the stator ring; starting at the gas entry center line this area moved down the trailing edge from the blade tip (I.D.) to root (O.D.), across the root towards the leading edge for about two thirds of the chord, then up the blade span and finally back to the trailing edge tip (I.D.).

On the convex face there was "medium" erosion over the leading half of the blade surface and an area of "high" erosion near the leading edge root (O.D.).

The erosion pattern on the two subsequent stator rows was basically similar to the first stage, except that the area of "high" erosion on the concave face was always located near the trailing edge root (O.D.) and increased in size in successive rows.

The erosion rate on the blade platforms varied from "low" to "medium."

On the concave face of the first stage rotor blade the rate of erosion increased progressively from the leading to trailing edge, while on the convex face there was an area of "high" erosion near the leading edge on the outer three quarters of the span, which gave way to "medium" erosion in the mid-chord area with "no" erosion near the trailing edge. There was also a small area of "high" erosion near the leading edge root on the convex face.

The pattern of erosion on the second and third stage blade surfaces was basically similar to that in the first stage with the exception that the "high" erosion rate near the leading edge on the convex face was limited to the outer half of the blade span. 
In all rotor stages, erosion was "high" on the verical step below the leading edge and "medium" or "high" on the corresponding blade platform. Erosion was "low" on the trailing blade platform.

The various flow conditions described by Junge (Ref. 32) which contribute to local variations in the concentration of ash particles and hence affect erosion rates are relevant to the erosion patterns determined during this test series.

Due to gas deflection within the blade passages the solid particles, particularly in the larger sizes, are centrifuged towards the concave face; their impact with the blade produces the "high" to "medium" erosion rates evident near the trailing edge of both stator and rotor blades.

Superimposed on this, the high swirl velocity of the mean gas stream centrifuges the particles towards the outer wall. This action is reinforced by the rotor transport action whereby particles entering the low relative velocity areas of the boundary layer, separated flow regions and rotor blade wake will also be centrifuged towards the outer wall. Some evidence of this concentration of particles in the outer annulus is presented by the fact that all areas of "high" erosion on the second and third row stator blades occur in this region.

Erosion on the convex face of a blade near the leading edge is typical of that produced by particles, and particularly the larger sizes, which do not reach the full gas velocity and hence enter the blade passage with a negative angle of incidence and strike the blade on the convex surface. This form of erosion is evident on all stator and rotor blades, and is more severe between the mid-span and outer diameter, probably due to the concentration of the larger particles in this region.

Some of the smallcr ash particles whlch follow the gas stream more readily are probably caught up in the end whirl and the stator trailing edge wake secondary flows, which are fed from low momentum gas in the boundary layer on the outer wall and from the blade pressure surface where these particles are then transported towards the inner diameter in the direction of the pressure gradient produced by the vortcx flow. In the iedeslyned curbine the fence incorporated into the trailing edge of the stator at about midspan stops the particles from migrating onto the outer half of the blades. These particles then probably enter the stator wake and strike the convex face near the leading edge of the rotor blade, to be cencrifuged outwards and add to the erosion in this region. It is perhaps significant that the outer surface of the fence showed some polishing, and that the "high" erosion on the outer part of the rotor blades in the second and third stage commences opposite the fence.

Some of the particles being transported over the inner half of the stator blades are entrained in the stator tip leakage flow. This high velocity flow is produced by the pressure difference across the stator blade (between the pressure and suction surfaces) 
and impinges on the rotor drum as it passes under the stator tip, and then on the vertical step in front of the rotor blade root, producing "medium" and "high" erosion in these areas. The partic.les then probably come under the influence of the main gas stream flow and strike the convex face of the rotor blades near the leading edge root producing a localized area of "high" erosion. The highly polished nature of these areas near the rotor blade root suggests that the finer ash particles are responsible.

In the original two-stage turbine the undercutting of the leading edge root of the rotor blade by ash entrained in the tip leakage flow was a serious problem. The fence on the stator blade trailing edges appears to be effective in reducing the amount of ash migrating to the inner wall, and in distributing the intercepted ash over a reasonable area of the lighter stressed outer rotor blade section. Recessing the stator blades below the root of the rotor blades also appears effective since the brunt of the erosion is taken on the vertical step in front of the rotor, and the ash impinging on the rotor root is spread over a larger area than in the original two-stage machine.

The reasons for the variation in erosion rate from row to row (Tables A.23 and A.24) are not so obvious, but the trends shown in the redesigned turbine are consistent with these observed in the original two-stage machine. A possible explanation of the low erosion rate in the first stage stator blades is that, although the mean relative gas velocities do not vary greatly from stage to stage, the solid particles entering the inlet volute with zero axial velocity may not have been accelerated to velocities approaching that of the gas before they enter the first row stators. If, on reaching the first stage rotor the velocity of the particles is still appreciably lower than the gas velocity they will enter the blade passage with a negative angle of incidence, which may explain the somewhat higher erosion rate in this rotor row. This view is supported by the relatively large area of "high" erosion on the convex face near the leading edge of the first row rotors.

The rotor and stator blade erosion rates obtained from the operation of the original and redesigned turbine are summarized in Tables A.26 and

A.27. An assessment of the effects of the turbine redesign upon blade life, made by ARL (Ref. 33), is given below.

The effect of the change of gas velocity in the two turbines on the erosion rate can be assessed from the stage metal loss per kilogram of ash under the various operating conditions; this erosion rate, together with an estimate of the corresponding stage exit gas velocity, is listed in Table A.28 for Greta Test 4 with the original turbine and for the redesigned machine.

The blade materials in the original and redesigned compressor turbine are Nimonic and H.S. 31 alloys respectively; previous 
Table A.26. Rotor blade erosion rates (Ref. 33)

\begin{tabular}{|c|c|c|c|c|}
\hline Test & $\begin{array}{l}\text { Solids rate } \\
(\mathrm{kg} / \mathrm{hr})\end{array}$ & $\begin{array}{c}\text { Mean particle } \\
\text { size } \\
(\mu)\end{array}$ & $\begin{array}{l}\text { Trosion rate } \quad \text { Specific erosion rate } \\
\left(\mathrm{mg} / \mathrm{cm}^{2} \times \mathrm{hr}\right)\left[\left(\mathrm{mg} / \mathrm{cm}^{2} \times \mathrm{kg} \text { solids }\right) \times 10^{3}\right]\end{array}$ & $\begin{array}{l}\text { Total erosion } \\
\text { rate per stage } \\
\text { (mg/kg solids) }\end{array}$ \\
\hline \multicolumn{5}{|c|}{ High-pressure turbine - first stage rotor blade } \\
\hline \multicolumn{5}{|l|}{ Greta" coal } \\
\hline 1 & 48.0 & 22 & 2.65 & 123.7 \\
\hline 2 & 71.8 & 30 & 72.5 & 162.4 \\
\hline 3 & 8.4 & $5.5-6.4$ & 20.6 & 46.1 \\
\hline 4 & 13.2 & $6.0-8.0$ & 15.0 & 35.5 \\
\hline Callide coal & 52.2 & $4.6-6.4$ & 18.5 & 41.4 \\
\hline 3-stage turbine & 22.3 & $4.3-7.8$ & 0.89 & 2.7 \\
\hline \multicolumn{5}{|c|}{ High-pressure turbine - second stage rotor blade } \\
\hline \multicolumn{5}{|l|}{ Greta coal } \\
\hline 1 & 48.0 & 20.6 & 33.5 & 97.3 \\
\hline 2 & 71.8 & 28.0 & 3.22 & 130.4 \\
\hline 3 & 8.4 & $5.2-6.0$ & 0.11 & 39.4 \\
\hline 4 & 13.2 & $5.6-7.5$ & 0.14 & 31.3 \\
\hline Callide coal & 52.2 & $4.3-6.0$ & 0.70 & 33.6 \\
\hline 3-stage turbine & 22.3 & $4.0-7.7$ & 0.012 & 1.9 \\
\hline \multicolumn{5}{|c|}{ High-pressure turbine - third stage rotor blade } \\
\hline 3-stage turbine & 22.3 & $3.7-7.6$ & 0.013 & 2.3 \\
\hline \multicolumn{5}{|c|}{ Low-pressure turbinc - first atagc rotor blade } \\
\hline \multicolumn{5}{|l|}{ Olela Lual } \\
\hline 1 & 48.0 & 19.3 & 0.18 & 19.2 \\
\hline 2 & 71.8 & 26.5 & 0.43 & 30.0 \\
\hline 3 & 8.4 & $4.8-5.6$ & 0.012 & 7.4 \\
\hline 4、 & 13.2 & $5.3-7.0$ & 0.009 & 3.7 \\
\hline Callide coall & 52.2 & $4.0-5.6$ & 0.06 & 6.0 \\
\hline 3-stage turbine & 22.3 & $3.4-7.6$ & 0.02 & 4.6 \\
\hline \multicolumn{5}{|c|}{ Low-pressure turbine - second stage rotor blade } \\
\hline \multicolumn{5}{|l|}{ Greta coal } \\
\hline 1 & 48.0 & 17.9 & 0.14 & 16.1 \\
\hline 2 & 71.8 & 24.7 & 0.344 & 27.4 \\
\hline 3 & 8.4 & $4.4-5.2$ & 0.013 & 8.9 \\
\hline 4 & 13.2 & $4.8-6.5$ & 0.008 & 3.5 \\
\hline Callide coal & 52.2 & $3.5-5.2$ & 0.06 & 6.5 \\
\hline 3-stage turbine & 22.3 & $3.1-7.5$ & 0.019 & 5.0 \\
\hline
\end{tabular}

teete in the original turbine (Tables $\Lambda .26$ and $\Lambda .27$ ) showed that the erosion rate of H.S. 31 is about half that of the Nimonic alloys. To give a more meaningful comparison of the erosion rates in the redesigned and the original compressor turbines and in the power turbine, the corresponding erosion rates that would apply if the redesigned turbine had been fitted with blades made of Nimonic alloy are shown in brackets in Table A. 28 .

In comparison with that in the original turbine, metal loss per kilogram of ash in the redesigned compressur lurbine (assuming the use of Nimonic blading) was reduced by factors of 6.6 and 8.2 for the first and second row rotor blades respectively, and by a factor of 4.7 for the first and second stage stator blades. 
Table A.27. Stator blade erosion rates (Ref. 33)

\begin{tabular}{|c|c|c|c|c|c|c|c|c|c|c|c|c|}
\hline \multirow{2}{*}{ Test } & \multirow{2}{*}{$\begin{array}{l}\text { Solids } \\
\text { rate } \\
\text { (kg/hr) }\end{array}$} & \multirow{2}{*}{$\begin{array}{l}\text { Mean } \\
\text { particle } \\
\text { size } \\
(\mu)\end{array}$} & \multirow{2}{*}{$\begin{array}{c}\text { To:al } \\
\text { erosiun per } \\
\text { stage } \\
\text { (mg } / \mathrm{kg} \text { solids) }\end{array}$} & \multicolumn{9}{|c|}{$\begin{array}{l}\text { Average specific erosion rate } \\
{\left[\left(\mathrm{mg} / \mathrm{cm}^{2}-\mathrm{kg} \text { solids }\right) \times 10^{3}\right]}\end{array}$} \\
\hline & & & & Nimonic $30 \AA$ & II.S.31 & N. 155 & Chrome plate & Chromized & Aluminized & C. 242 & L.H. 5 & H.R.Cr.max \\
\hline
\end{tabular}

High-pressure turbine - first stage stator blades

$\begin{array}{lrcc}\text { Greta coal } & & & \\ 1 & 48.0 & 22 & 85.7 \\ 2 & 71.8 & 30 & 127.3 \\ 3 & 8.4 & .5 .5-6.4 & 23.8 \\ 4 & 13.2 & 6.0-8.0 & 12.2 \\ \text { Callide coal } & 52.2 & 4.6-6.4 & 23.4 \\ \text { 3-stage turbine } & 22.3 & 4.3-7.8 & 1.28^{b}\end{array}$

$\begin{array}{lrrr}\text { Sreta coal } & & & \\ 1 & 48.0 & 20.6 & 96.5 \\ 2 & i 1.8 & 28.0 & 143.8 \\ 3 & 8.4 & 5.2-0.0 & 36.4 \\ 4 & 13.2 & 5.6-7.5 & 26.0 \\ \text { Callide coal } & 52.2 & 4.3-0.0 & 42.6 \\ \text { 3-stage turbine } & 22.3 & 4.0-7.7 & 2.80\end{array}$

High-pressure turbine - second stage stator blades

\begin{tabular}{|c|c|c|c|c|c|c|c|c|}
\hline 45.1 & 18.9 & 24.2 & 3.8 & 21.0 & & & & \\
\hline 67 & 30.0 & 41.5 & 7.0 & 43.17 & & & & \\
\hline 12.5 & 5.9 & 4.2 & 2.8 & $3.9^{\circ}$ & & & & \\
\hline 6.4 & 2.0 & 0.7 & 1.2 & 0.7 & & & & \\
\hline 12.3 & $\begin{array}{l}3.3 \\
0.42\end{array}$ & 5.1 & 2.0 & $\begin{array}{l}\text { Very low } \\
\text { very low }\end{array}$ & Very low & 5.3 & 10.1 & 2.2 \\
\hline
\end{tabular}

$\begin{array}{rrrr}32.6 & 28.2 & & 3.4 \\ 48.6 & 41.3 & & 4.8 \\ 12.3 & 8.6 & & 0.7 \\ 8.8 & 4.2 & & 0.3 \\ 14.4 & 7.4 & 10.0 & 1.7\end{array}$

$\begin{array}{rr} & 42.5 \\ & 11.7 \\ 1.3 & 5.3 \\ & 9.0\end{array}$

High-pressure turbine - third stage stator blades

$\begin{array}{llllll}3 \text {-stage turbine } & 22.3 & 3.7-7.6 & 3.14^{\text {b }} & 0.80 & \text { Very low }\end{array}$

Low-pressure turbine - first stage stator blades

$\begin{array}{crccc}\text { Greta coal } & & & & \\ 1 & 48.0 & 19.3 & 23.1 & 4.17 \\ 2 & 71.8 & 26.5 & 51.5 & 9.34 \\ 3 & 8.4 & 4.8-5.5 & 5.3 & 0.96 \\ 4 & 13.2 & 5.3-7.5 & \vdots .3 & 0.60 \\ \text { Callide coal } & 52.2 & 4.0-5.6 & 17.4 & 1.89 \\ \text { 3-stage turbine } & 22.3 & 3.4-7.6 & 4.52 & 0.82\end{array}$

Low-pressure turbine - second stage stator blades

\begin{tabular}{|c|c|c|c|c|c|}
\hline \multicolumn{6}{|l|}{ Greta Coal } \\
\hline 1 & 48.0 & 17.9 & $2 ! .9$ & $4 ., 20$ & All blades in this stage are Nimonic $80 \mathrm{~A}$ \\
\hline 2 & 71.8 & 24.7 & Sc. 2 & 8.80 & \\
\hline 3 & 8.4 & $4.4-5.2$ & $1: .9$ & 1.94 & \\
\hline 4 & 13.2 & $4.8-6.5$ & 6.2 & 1.0 & \\
\hline Callide Coal & 52.2 & $3.5-5.2$ & 13.9 & 2.26 & \\
\hline
\end{tabular}

${ }^{a}$ Column 4 gives the total erosion per sage assuming the row was composed entirely of Nimonic goA blates.

bi.s.31. 
Tatile A.28. Corresponding erosion rates for standard and redesigned zurtine (Ref. 33)

\begin{tabular}{|c|c|c|c|c|c|c|c|c|c|}
\hline & \multicolumn{5}{|c|}{ Conpressor (H.F.) turbine } & \multicolumn{4}{|c|}{ Pcwer (L.P.) turbine } \\
\hline & \multicolumn{2}{|c|}{$\begin{array}{c}s \text {-antard =urbine } \\
(\text { Grata test } L)\end{array}$} & \multicolumn{3}{|c|}{ Redesigned turbine } & \multicolumn{2}{|c|}{$\begin{array}{c}\text { Standard =urtine } \\
\text { (Greta test } 4 \text { ) }\end{array}$} & \multicolumn{2}{|c|}{ Redesigned turbine } \\
\hline & \multirow{2}{*}{$\begin{array}{l}\text { Exi: } \\
\text { velocity } \\
(\text { fpsi }\end{array}$} & \multirow{2}{*}{$\begin{array}{l}\text { St.age erosion } \\
\text { (ng/kg ash) }\end{array}$} & \multirow{2}{*}{$\begin{array}{l}\text { Exit } \\
\text { velocity } \\
\text { (fps) }\end{array}$} & \multicolumn{2}{|c|}{$\begin{array}{l}\text { Stage erosion } \\
(\mathrm{mg} / \mathrm{kg} \text { ash) }\end{array}$} & \multirow{2}{*}{$\begin{array}{l}\text { Exit } \\
\text { velocity } \\
\text { (fps) }\end{array}$} & \multirow{2}{*}{$\begin{array}{l}\text { Stage erasion } \\
\text { (ng/kg ash) }\end{array}$} & \multirow{2}{*}{$\begin{array}{l}\text { Exit } \\
\text { velocity } \\
\text { (fps) }\end{array}$} & \multirow{2}{*}{$\begin{array}{c}\text { Stage erosion } \\
\text { Nimonic } \\
(\mathrm{mg} / \mathrm{kg} \text { ash) }\end{array}$} \\
\hline & & & & H. $\subseteq .31$ & Nimonic & & & & \\
\hline \multicolumn{10}{|l|}{ Rotors } \\
\hline First stage & 93ำ & 35.5 & $: 70$ & 2.71 & 5.4 & 670 & 5.7 & 750 & 4.58 \\
\hline Second stage & 930) & 31.3 & $: 70$ & 1.91 & 3.8 & 670 & 3.5 & 750 & 5.00 \\
\hline Third stage & & & $: 70$ & 2.32 & 4.6 & & & & \\
\hline \multicolumn{10}{|l|}{ Stators } \\
\hline First stage & $10(11)$ & 12.1 & 810 & 1.28 & 2.6 & 720 & 3.3 & 784 & 4.52 \\
\hline Second stage & $10(11)$ & 26.0 & 810 & 2.82 & 5.6 & 720 & 6.1 & 784 & 7.19 \\
\hline Third stage & & & 810 & 3.14 & 6.3 & & & & \\
\hline
\end{tabular}


In general, a turbine blade operating in an erosive environment must be replaced if either:

(a) the increase in blade stress produced by undercutting of

the root section, or

(b) the loss in aerodynamic performance due to changes in blade profile, reaches an unacceptable limit.

Previous analyses on the original Ruston and Hornsby turbine showed that in this conventional machine, designed for a blade life of 100,000 hours with liquid fuel, the loss in aerodynamic performance was the limiting factor. This is also likely to be the case in the redesigned compressor turbine, particularly since the stator blade trailing edge fence and the recessing of the stator blade tip below the rotor blade root appear to have reduced the undercutting of the rotor blade root.

In the assessment of blade life it was assumed that the blades reach the end of their useful life when the trailing edge thickness [originally $0.060 \mathrm{in.}(1.5 \mathrm{~mm})$ ] has been reduced to zero. It will be noted in the blade erosion patterns that the trailing edge is worn on the concave surface only, and that on this face the erosion rate is zero near the leading edge, and in general increases along the blade chord through "medium" to "high" rates at the trailing edge. Hence it was assumed that the wear on the concave face would increase uniformly from zero at the leading edge to 0.060 in. (1.5 $\mathrm{mm})$ at the trailing edge.

It was further assumed that during this period the other areas of the blades classified as "high," "medium," "low" and "zero" erosion would be worn to depths of $0.060,0.040,0.020$ and 0.000 in. $(1.5,1.0,0.5,0 \mathrm{~mm})$ respectively.

From the measured areas on the blade corresponding to each of the four erosion rates, the total metal loss per blade was computed; this together with the experimentally determined total metal loss per blade per hour gave the estimated life of the blade. The lives, based on the mean erosion rate per stage, are listed in Table A. 29.

Because of the non-uniform ash distribution at the entrance to the turbine, the erosion rate and hence the blade life vary

Table A.29. Estimated mean H.S.31

blade lives - compressor

turbine (hr) (Ref. 33)

\begin{tabular}{lll}
\hline & Rotors & Stators \\
\hline First stage & 31,000 & 51,000 \\
Second stage & 52,000 & 25,000 \\
Third stage & 51,000 & 27,000 \\
\hline
\end{tabular}


around the stator row. The number of stator blades in the redesigned turbine having a life in a specific range is shown in Table. A.30. This illustrates the importance of the inlet volute design in a gas turbine operating on dirty gases and emphasizes that care should be taken to produce an ash distribution as close to uniform as practicable at the inlet to the turbine.

Table A.30. Number of stator blades with stated life range (Ref. 33)

\begin{tabular}{lccc}
\hline \multirow{2}{*}{$\begin{array}{c}\text { B1ade } 1 \text { ife } \\
\left(\text { hr } \times 10^{3}\right)\end{array}$} & First stage & Second stage & Third stage \\
\cline { 2 - 4 } & & 5 & \\
$10-15$ & 2 & 7 & 10 \\
$15-20$ & 3 & 8 & 12 \\
$20-25$ & & 5 & 4 \\
$25-30$ & 10 & 9 & 10 \\
$30-40$ & 15 & 6 & 8 \\
$40-50$ & 21 & 9 & 4 \\
$50-80$ & 13 & & \\
$80+$ & & & \\
\hline
\end{tabular}

\section{Slı11 Development Company}

In 1950 the Elliott Company drove a gas compressor with a singlestage turbine installed in the exhaust gas stream from a catalytic regenerator in a small refinery in ohio. ${ }^{37}$ No separation equipment was installed ahead of the turbine and by the end of $750 \mathrm{hr}$ of operation, the turbine was considered to be virtually useless. ${ }^{37,40}$

The Elliott experiment and the development of the coal-fired gas turbine focused attention upon the need for gas cleanup ahead of the turbine. The Shell Oil Development Company installed a gas-turbine-driven air compressor in the East Montreal refinery in 1957.41 The installation was similar to the Elliott experiment except that a separator was installed ahead of the turbine inlet to remove enough of the particulate material from the flue gas stream to prevent serious erosion of the turbine blading. The turbine was operated with an inlet temperature of approximately $1100^{\circ} \mathrm{F}$ 
$\left(594^{\circ} \mathrm{C}\right)$ for $4000 \mathrm{hr}$. After the 4000 -hr test, examination of turbine indicated only minor polishing of the blades. ${ }^{40}$ To demonstrate the contribution of the separator, it was removed from the system and the turbine was operated as in the Elliott experiment. After $650 \mathrm{hr}$, the turbine efficiency decreased from 79 to $49 \%$. Erosion was severe in both stator and rotor blades. ${ }^{37}$ During this phase of the experiment, the particulate concentration in the turbine inlet stream was approximately $1300 \mathrm{ppm}$ and a particle size range of $50 \%$ plus $20 \mu \mathrm{m}$ and $80 \%$ greater than $10 \mu \mathrm{m} .{ }^{40}$

Based upon the Montreal experiment, the Shell Oil Company in 1962 began the installation of turbines in the flue gas stream of the catalytic regenerators in both new and existing refineries. Table A.30 (Ref. 37) lists typical refinery installations made between 1963 and 19,73 .

Actual field results of separation taken in 1968 from the Deer Park, Texas, installation (see Table A.31) are given in Table A.32. ${ }^{4}$

Table A.31. Refinery power recovery worldwide by U.S. manufacturers (Ref. 37)

\begin{tabular}{|c|c|c|c|c|c|}
\hline Refinery & Location & Driven equipment & Expander hp & Expander mfr. & Startup \\
\hline Shell Oil & Norco, La. & Clark cent. comp. & 9,000 & Ingersoll-Rand & Aug. 1963 \\
\hline Shell 011 & Oakville, Ont. & Elliott, cent. comp. & 4,000 & Elliott & Nov. 1963 \\
\hline Shell oil & Deer Park, Tex. & I-R cent. comp. & 7,000 & Ingersoll-Rand & Sept. 1964 \\
\hline Shell Oil & Martinez, Cal. & I-R Axial comp. C.E. motor/generator & 15,700 & Ingersol1-Rand & Aug. 1966 \\
\hline Humble & Bayway, N.J. & $\begin{array}{l}\text { Elliott cent. comp. Westinghouse } \\
\text { motor/gen. }\end{array}$ & 20,000 & Elliott & Dec. 1967 \\
\hline Shell 011 & Berre, France & I-R cent. comp. French motor/gencrator & 6,000 & Ingersoll-Rand & Sept. 1970 \\
\hline Gulf oil. & Edmonton, Alta. & I-R cent. comp. & $6,000 / 9,000$ & Ingersoll-Rand & July 1971 \\
\hline Sun $0 i 1$ & Toledo & I-R axial comp. Westinghouse motor/gen & 22,000 & Ingersol1-Rand & Spring 1973 \\
\hline
\end{tabular}

Table A.33 shows the extremes of the particle-size distribution which have been encountered in actual operation. The data are not related directly to the data in Table A.32. ${ }^{41}$

Turbine blades fabricated from tungsten-carbide-flame-coated A-286 [for $1150^{\circ} \mathrm{F}\left(620^{\circ} \mathrm{C}\right)$ service] and Inconel $\mathrm{X}$ [for $1200^{\circ} \mathrm{F}\left(650^{\circ} \mathrm{C}\right)$ ] have a life expectancy of 25 to $35,000 \mathrm{hr}$ without significant power reduction caused by erosion. ${ }^{39,43,44}$ No difficulties with deposits in these installations have been reported after nearly 13 years of commercial operation. 
Table A.32. Flue-gas loadings in cyclones $^{a}$ and separator (Ref. 41)

\begin{tabular}{lcrr}
\hline & $\begin{array}{l}\text { Flue-gas } \\
\text { loading } \\
\text { (tons/day) }\end{array}$ & $\begin{array}{c}\text { Catalyst } \\
\text { concentration } \\
\text { [ppm (wt) }\end{array}$ & $\begin{array}{r}\text { Catalyst } \\
\text { loading } \\
\text { (tons/day) }\end{array}$ \\
\hline Entering 1st-stage cyclone & 5000 & $3,000,000$ & 15,000 \\
Entering 2nd-stage cyclone & 5000 & 20,000 & 100 \\
Entering 3rd-stage separator & 5000 & 800 & 4 \\
Entering turboexpander & 4900 & $120-160$ & $0.6-0.8$ \\
\hline
\end{tabular}

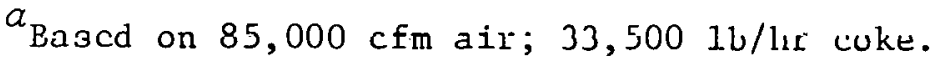

'lable A.33. Catalyot oirc diotribution (\%)

in cyclones and separator (Ref. 41)

\begin{tabular}{lccc}
\hline & $\begin{array}{c}\text { Entering } \\
\text { cyclones }\end{array}$ & $\begin{array}{c}\text { Entering } \\
\text { separator }\end{array}$ & $\begin{array}{c}\text { Leaving } \\
\text { separator }\end{array}$ \\
\hline $80 \mu \mathrm{m}$ & $17-36$ & & \\
$40-80 \mu \mathrm{m}$ & $75-83$ & $3-16$ & \\
$20-40 \mu \mathrm{m}$ & $18-1$ & $23-54$ & 3 \\
$10-20 \mu \mathrm{m}$ & & $34-22$ & $5-17$ \\
$4-10 \mu \mathrm{m}$ & & $14-8$ & $15-40$ \\
$2-4 \mu \mathrm{m}$ & & $14-3$ & $80-40$ \\
$0-2 \mu \mathrm{m}$ & & $17-3$ & \\
\hline
\end{tabular}


ORNL/TM-6253

Dist. Category UC-90f

Internal Distribution

$\begin{aligned} \text { 1. } & \text { E. C. Fox } \\ 2 . & \text { A. P. Fraas (consultant) } \\ 3 . & \text { T. G. Godfrey } \\ 4-7 . & \text { R. L. Graves } \\ 8-12 . & \text { R. S. Holcomb } \\ 13 . & \text { J. M. Holmes } \\ 14 . & \text { J. E. Jones, Jr. } \\ 15-24 . & \text { M. E. Lackey } \\ 25 . & \text { R. E. MacPherson } \\ 26 . & \text { L. E. McNeese } \\ 27 . & \text { T. W. P1ckel }\end{aligned}$

1. E. C. Fox

2. A. P. Fraas (consultant)

3. T. G. Godfrey

4-7. R. L. Graves

13. J. M. Holmes

24. M. E. Lackey

26. L. E. McNeese

27. T. W. Plckel

\author{
28. H. Postma \\ 29. M. W. Rosenthal \\ 30. I. Spiewak \\ 31. H. E. Trammell \\ 32. D. B. Trauger \\ 33. G. P. Zimmerman \\ 34. ORNL Patent Office \\ 35-36. Central Research Library \\ 37. Document Reference Section \\ 38-40. Laboratory Records Department \\ 41. Laboratory Records, RC
}

\section{External Distribution}

42. S. Alpert, EPRI, 3412 Hillview Ave., Palo Alto, Calif. 94304

43. D. H. Archer, Westinghouse Research Laboratory, 1310 Beulah Road, Pittsburgh, Pa. 15235

44. J. T. Bartis, Planning and System Engineering, DOE Fossil Energy, MS-C-164, Germantown, Washington, D.C. 20504

45. D. H. Broadbent, National Coal Board (IEA Services Ltd.), 14/15 Lower Grosvenor Place, London, England

46. R. D. Brooks, General Electric Co., Energy Systems and Technology Division, B1dg. 2, Schenectady, N.Y. 12345

47. Robert Brookshire, Tennessee Valley Authority, 440 Commerce Union Bank Bldg., Chattanooga, Tenn. 37401

48. John Byam, Morgantown Energy Research Center, P.0. Box 880, Morgantown, W.Va. 26505

49. N. H. Coates, The Mitre Corp., Westgate Research Park, McLean, Va. 22101

50. A. Cohn, EPRI, 3412 Hillview Ave., Palo Alto, Calif. 94304

51. H. G. Corneil, Exxon Enterprises, Inc., 1251 Avenue of the Americas, New York, N.Y. 10020

52. Russell Cove11, Combustion Englneering, Inc., 1000 Prospect Hill Road, Windsor, Conn. 06095

53. E. L. Daman, Foster Wheeler Corp., 110 S. Orange Ave., Livingston, N.J. 07039

54. Shelton Ehrlich, EPRI, 3412 Hillview Ave., P.0. Box 10412, Palo Alto, Calif. 94304

55. John Eustis, DOE, Washington, D.C. 20545

56. E. C. Feher, TRW, Mail Station 01/2270, 1 Space Park, Redondo Beach, Calif. 90278

57. T. J. Fitzgerald, Oregon State University, Chemical Engineering Department, Corvallis, Ore. 97331

58. R. W. Foster-Pegg, Westinghouse Electric Corp., Gas Turbine Engine Division, P.O. Box 9175, Philadelphia, Pa. 19113 
59. Steven Freedman, Coal Conversion and Utilization, Division of Fossil Energy Research, DOE, Washington, D.C. 20545

60. J. A. Fullam, Ingersoll-Rand Co., Process Compressor and Expanders, Turbo Products Division, Phillipsburg, N.J. 08865

61. F. D. Gmeind1, Morgantown Energy Research Center, P.0. Box 880 , Morgantown, W.Va. 26505

62. G. H. Goff, Research and Engineering, Bechtel Corp., 50 Beale St., San Francisco, Calif. 94119

63. Jerry Golden, Tennessee Valley Authority, Knoxville Office Complex, 400 Commerce Avenue, W10Al9, Knoxville, Tenn. 37902

64. W. B. Harrison, Southern Company Services, Inc., P.O. Box 2625, Birmingham, Ala. 35202

65. H. R. Hazard, Battelle Columbus Laboratories, 505 King Avenue, Columbus, Ohio 43201

66. T. A. Hetrick, Elliott Company, Jeannette, Pa. 15644

67. R. C. Hoke, Exxon Research and Engineering Co., P.O. Box 8, Linden, N.J. 07036

68. J. J. Horgan, United Technologies Corporation, P.0. Box 109, South Windsor, Conn. 06109

69. H. R. Hoy, Director, Leatherlead Laboratory, National Coal Board (BCURA, Ltd.), Randalls Road, Leatherhead, Surrey, England

70. D. L. Keairns, Westinghouse Research Laboratory, 1310 Beulah Road, Pittsburgh, Pa. 15235

71. C. W. Knudson, General Electric Co., Energy Systems and Technology Division, BIdg. 2, Schenectady, N.Y. 12345

72. L. R. Lawrence, Jr., Gas Research Institute, 3424 S. State St., Ch1cago, Il1. 60616

73. J. F. Louis, Massachusetts Institute of Technology, 77 Massachusetts Avenue, Energy Laboratory, Room 31-254, Cambridge, Mass. 02139

74. T. E. Lund, EPRI, 3412 HIllvlew Avellue, P.0. Bux 10412, Palo Alto, Calif. 94304

75. J. J. Markowsky, American Electric Power, 2 Broadway, New York, N.Y. 10004

76. C. H. Marston, General Electric Company, 1 River Road, Schenectady, N.Y. 12345

77. M. J. Mayfield, Tennessee Valley Authority, 440 Commerce Union Bank Bldg., Chattanooga, Tenn. 37401

78. J. L. Morgan, Ceneral Elcctric Co:, 1 River Road, Gehenectady, N.Y. 12345

79. Seymour Moskowitz, Curtiss-Wright Corp., One Passaic Street, Wood-Ridge, N..J. 0707.5

80. Abolhassan Nazemi, The MITRE Corp./METREK Division, Westgate Research Park, McLean, Va. 22101

81. W. T. Newberry, Tennessee Valley Authority, 440 Commerce Union Bank Bldg., Chattanooga, Tenn. 37401

82. Kent Philips, Combustion Power Company, Inc., Memlo Park, Calif. 94025

83. Jim Powe11, Brookhaven National Laboratory, Department of Applied Science, Upton, N.Y. 11973

84. Lynn Rubow, Gilbert Associates, P.0. Box 1498, Reading, Pa. 19603 
85. L. I. Shure, NASA-Lewis Research Center, 21000 Brookpark Road, Cleveland, Ohio 44135

86. Lyle Six, AiResearch Mfg. Co., 402 South 36 th Street, Phoenix, Ariz. 85034

87. J. W. Smith, Babcock and Wilcox, 20 South Van Buren Avenue, Barberton, Ohio 44203

88. E. V. Somers, Westinghouse Electric Corp., Research and Deve1opment Center, Church111 Boro, Pittsburgh, Pa. 15235

89. A. M. Squires, Department of Chemical Engineering, Virginia Polytechnic Institute, Blacksburg, Va.

90. Beno Sternlicht, Mechanical Technology, Inc., 968 Albany Shaker Road, Latham, N.Y. 12110

91. R. H. Tourin, Program Director, New York State ERDA, 230 Park Avenue, New York, N.Y. 10017

92. J. G. Vlahakis, DOE, Washington, D.C. 20545

93. G. E. Voelker, Fossil Fuel Utilization, DOE Fossil Energy, MS-E-178, Germantown, Washington, D.C. 20504

94. J. F. Weinhold, Tennessee Valley Authority, 1345 Commerce Union Bank Bldg., Chattạnooga, Tenn. 37401

95. G. C. Weth, Fossil Fuel Utilization, DOE Fossil Energy, MS-E178, Germantown, Washington, D.C. 20504

96. D. M. Willyoung, General Electric Co., 1 River Road, Schenectady, N.Y. 12345

97. H. W. Withers, Tennessee Valley Authority, 440 Commerce Union Bank Bldg., Chattanooga, Tenn. 37401

98. F. A. Zenz, F. A. Zenz, Inc., P.O. Box 205, Garrison, N.Y. 10524

99. W. Zimmerman, General Electric Co., Advanced Energy Program, Evendale, Ohio 45215

100. Asst. Manager, Energy Research and Development, DOE-ORO

101-324. Given distribution as shown in TID-4500 under category UC-90f 